VINICIUS ALVIM PASSOS BALDACIM

Metabolismo e resposta imune celular no sangue de vacas Holandesas no período de transição

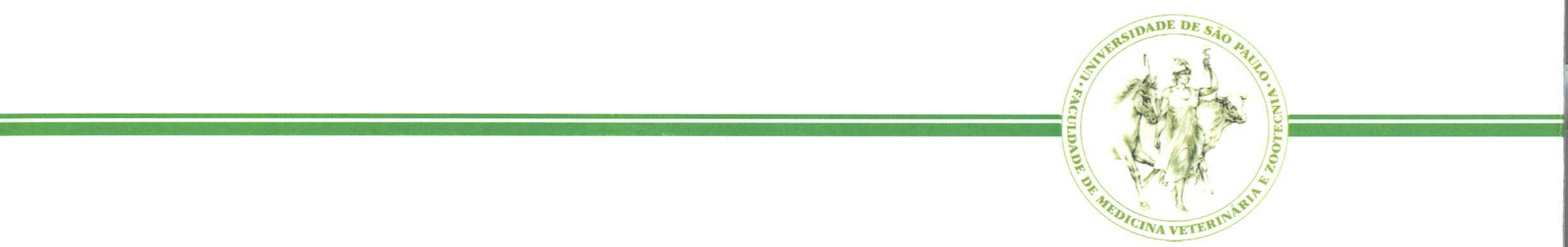




\section{Metabolismo e resposta imune celular no sangue de vacas Holandesas no período de transição}

Dissertação apresentada ao Programa de Pós-Graduação em Clínica Veterinária da Faculdade de Medicina Veterinária e Zootecnia da Universidade de São Paulo para obtenção do título de Mestre em Ciências

\section{Departamento:}

Clínica Médica

Área de concentração:

Clínica Veterinária

Orientador:

Prof $^{\mathrm{a}}$. Dr ${ }^{\mathrm{a}}$. Viviani Gomes

De acordo:

Orientador

São Paulo

2014 
Autorizo a reprodução parcial ou total desta obra, para fins acadêmicos, desde que citada a fonte.

\section{DADOS INTERNACIONAIS DE CATALOGAÇÃO-NA-PUBLICAÇÃO}

(Biblioteca Virginie Buff D’Ápice da Faculdade de Medicina Veterinária e Zootecnia da Universidade de São Paulo)

Baldacim, Vinicius Alvim Passos

Metabolismo e resposta imune celular no sangue de vacas Holandesas no período de transição / Vinicius Alvim Passos Baldacim. -- 2014

$111 \mathrm{f}$ : : il.

Dissertação (Mestrado) - Universidade de São Paulo. Faculdade de Medicina Veterinária e Zootecnia. Departamento de Clínica Veterinária, São Paulo, 2014.

Programa de Pós-Graduação: Clínica Veterinária.

Área de concentração: Clínica Veterinária.

Orientador: Prof ${ }^{\mathrm{a}}$. Dr ${ }^{\mathrm{a}}$. Viviani Gomes. 


\section{CERTIFICADO}

Certificamos que o Projeto intitulado "Metabolismo e resposta imune celular no sangue de vacas Holandesas no período de transição", protocolado sob o n 2767/2012, utilizando 13 (treze) bovinos, sob a responsabilidade da Profa. Dra. Viviani Gomes, está de acordo com os princípios éticos de experimentação animal da "Comissão de Ética no uso de animais" da Faculdade de Medicina Veterinária e Zootecnia da Universidade de São Paulo e foi aprovado em reunião de 19/9/2012.

We certify that the Research "Metabolism and cellular immune response in blood of Holstein cows in the transition period", protocol number 2767/2012, utilizing 13 (thirteen) bovine, under the responsibility Profa. Dra. Viviani Gomes, agree with Ethical Principles in Animal Research adopted by "Ethic Committee in the use of animals" of the School of Veterinary Medicine and Animal Science of University of São Paulo and was approved in the meeting of day $9 / 19 / 2012$.

São Paulo, 17 de junho de 2014.

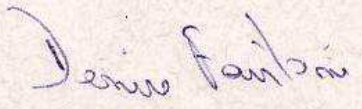

Denise Tabacchi Fantoni

Presidente 
Nome: BALDACIM, Vinicius Alvim Passos

Título: Metabolismo e resposta imune celular no sangue de vacas Holandesas no período de transição.

Dissertação apresentada ao Programa de Pós-Graduação em Clínica Veterinária da Faculdade de Medicina Veterinária e Zootecnia da Universidade de São Paulo para obtenção do título de Mestre em Ciências

Data:

Banca Examinadora

Prof. Dr.:

Instituição: Julgamento:

Prof. Dr.:

Instituição: Julgamento:

Prof. Dr.:

Instituição: Julgamento: 


\section{DEDICATÓRIAS}

Dedico esse trabalho à Deus primeiramente, pois tudo que conquistei foi observado por ele. Sempre me guiou para os melhores caminhos e me deu forças nas horas difíceis.

Aos meus pais pois sempre acreditaram em mim e fizeram de tudo para me deixar a herança mais preciosa que os pais podem dar a um filhos - A educação.

Ao meu irmão André que é meu amigo e companheiro para a vida toda e sempre pude contar a qualquer momento.

As minhas tias Ana e Sandra que sempre me acompanharam e apoiaram durante toda minha vida.

A minha amiga, colega e namorada que tive a alegria de conhecer durante $o$ mestrado, por todo companheirismo e amor que me deu.

A minha orientadora que acreditou em mim, e é exemplo de persistência nas realizações dos seus sonhos. 


\section{AGRADECIMENTOS}

Agradeço primeiramente a Deus por estar presente na minha vida, me dar força nos momentos difíceis, mas principalmente me trazer alegria de viver em qualquer situação. Obrigado por toda alegria que tive nesses dois anos que aqui estive.

Agradeço a minha Orientadora, que me acompanha desde a graduação. Obrigado por acreditar em mim, serei infinitamente grato por todo seu apoio, ensinamento e amizade. Nunca esquecerei das oportunidades que tive aqui. O que aprendi durante esse período levarei por toda minha vida.

Aos colegas de equipe: Camila, pela experiência que pude adquirir durante seu experimento, aos momentos de diversão e ajuda quando precisei; Cynthia, por seu companheirismo, amizade, ajuda e sua alegria em todos os momentos; Sylvia, pela companhia na fazenda e na faculdade, pelos momentos de diversão, amizade $e$ paciência em ajudar a mim e a todos durante todo o mestrado; Bruno, pela ajuda, companhia durante os tempos na fazenda, e aos momentos de diversão; Juliana, por sua importantíssima ajuda e momentos de descontração nas longas horas do experimento. Todos vocês foram muito importante durante o tempo que estive aqui e de alguma forma ajudaram no meu aprendizado e amadurecimento.

Agradeço a todos da minha família por sempre me apoiarem. Aos meus pais por todo esforço que fizeram em toda a suas vidas por mim, agradeço também por compreender toda minha ausência nesses anos. Agradeço ao meu irmão André e sua esposa Bianca por serem tão especiais comigo, por sempre fazer questão da minha companhia, mas sempre entender minha ausência. Senti muita falta do convívio com vocês. Agradeço minhas tias Ana e Sandra,pois durante minha vida sempre participaram da minha educação e da formação do meu caráter, vocês são muito especiais. Desculpe minha ausência e muito obrigado! Amo muito vocês!

Agradeço à Cynthia minha namorada que tive o prazer de conhecer durante $o$ mestrado, por toda ajuda que me deu durante o experimento, por sempre estar ao meu lado. Obrigado por fazer parte dessa importante história da minha vida, e por todo carinho e amor. Foi muito bom ter você ao meu lado. Te amo!! Agradeço também à sua família pelo carinho e por todas as orações.

Agradeço aos meus amigos que muitas vezes tive que me afastar, mas compreenderam minha ausência.

Agradeço aos colegas do Programa de Pós-Graduação pela amizade, ajuda, dicas, sugestóes, e conhecimento compartilhado, e claro, pelos momentos de diversão. 
Ao ilustre diretor da FMVZ/USP Prof. Dr. Enrico Lippi Ortolani e aos admirados professores do Departamento de Clínica Médica: Prof. Dr. Archivaldo Reche Junior, Prof. Dr. Carlos Eduardo Larsson, Prof. Dr. Fernando José Benesi, Prof $^{a}$ Dr $r^{a}$ Lílian Gregory, Prof ${ }^{a}$ Dr ${ }^{\underline{a}}$ Marcia Mery Kogika, Prof ${ }^{a}$ Dr ${ }^{a}$ Maria Cláudia Araripe Sucupira, Prof ${ }^{a}$ Dr ${ }^{\underline{a}}$ Maria Helena Matiko Akao Larsson, Prof ${ }^{a}$ Dr ${ }^{a}$ Mitika Hagiwara, Profa ${ }^{-} r^{a}$ Raquel Yvona Arantes Baccarin, Prof ${ }^{a}$ Dr ${ }^{a}$ Silvia Regina Ricci, e Prof. Dr. Wilson Roberto Fernandes.

Ao Prof Dr. Paulo Henrique Mazza Rodrigues pela disciplina de Planejamento de Experimento e Análise Estátistica, pois os conceitos foram importantíssimos para analise dos dados desta pesquisa.

Aos docentes da FZEA/USP que tive o prazer de tê-los como professor: Prof Dr. Celso da Costa Carrer, Prof. Dra. Fabiana Cunha Viana Leonelli, Prof. Dr. Paulo Morais, Prof. Dr. Raul Franzolin Neto, Prof. Dr. Runbens Nunes e Profa. Dra. Vivian Lara dos Santos Silva.

Ao Prof. Dr. David John Hurley da University of Georgia por nos receber em seu laboratório, pelas dicas e técnicas ensinadas. Sua ajuda contribuiu muito com o avanço nas pesquisas da equipe. Agradeço também sua família por toda receptividade conosco.

Agradeço a Prof. Dra. Karina Medici Madureira da UFBA,pelos bons momentos durante o treinamento na UGA e pela disponibilidade em ajudar.

À Samantha Ive Miyashiro pela ajuda e todas as duvidadas esclarecidas.

À Claudia Regina Stricagnolo pelos ensinamentos, apoio e principalmente paciência, nunca me esquecerei para que serve uma alça de repique.

À Clara Mori pela paciência, dúvidas esclarecidas e pelas analises realizadas durante o experimento.

À Edna Santana (Dinha) por todo carinho, conversa e atenção durante os dias no laboratório.

À toda equipe dos Laboratórios da FMVZ/USP, Maria Helena da Silva Pelissari, Marly Elizabethe Ferreira.

Ao Instituto de Zootecnia (APTA - Gado de Leite) pela disponibilidade em usar o local e os animais. À Juliana Rodrigues Pozzi Arcaro e Cláudia Rodrigues Pozzi pela confiança e atenção; Mariana Miranda pela ajuda e atenção; aos funcionários do IZ, Ana, Creusa, Donizete, Gilberto, Ivana, Izildinha, Teresa e Sr. Valter pela atenção, ajuda e toda paciência, vocês foram muito importantes para o bom andamento da pesquisa; e aos amigos da casa dos estudantes, pela companhia e ajuda durante os dias na fazenda. Foi muito bom os momentos que vivi e a experiência que pude adquirir em quanto estive ai. Obrigado a todos!

Ao Mailson pela ajuda e toda a dedicação e cuidado empregado aos animais da fazenda durante o experimento. Muito obrigado! 
Aos residentes do CBPR da época de 2012, 2013 e 2014. Durante esse tempo pude conhecer muita gente e fazer muito amigos. Vocês são especiais. Muito sucesso!

Ao Laboratório de Epidemiologia e Bioestatística - LEB por todas explicações e sugestões durante as Análises dos dados. Também ao Professor Dr. Ricardo Augusto Dias e a Doutoranda Aline Gil Alves Guillox pela atenção especial pesquisa.

Ao departamento VCM pela disponibilidade dos laboratórios na realização da A CAPES pela concessão da bolsa. 


\section{EPÍGRAFE}

"Finalmente irmãos, tudo o que é verdadeiro, tudo o que é honesto, tudo o que é justo, tudo o que é puro, tudo o que é amável, tudo o que é de boa fama, se alguma virtude há e se algum louvor existe, seja isso o que ocupe o vosso pensamento."

Filipenses 4:8 


\section{RESUMO}

BALDACIM, V. A. P. Metabolismo e resposta imune celular no sangue de vacas Holandesas no período de transição. [Metabolism and cellular immune response in blood of Holstein cows in the transition period]. 2014. $111 \mathrm{f}$. Dissertação (Mestrado em Ciências) - Faculdade de Medicina Veterinária e Zootecnia, Universidade de São Paulo, São Paulo, 2014.

O objetivo geral desta pesquisa foi avaliar o metabolismo e a resposta imune celular no sangue de vacas leiteiras no período de transição. Foram utilizadas 13 vacas Holandesas, de $2^{\underline{a}}$ a $4^{a}$ parição, avaliadas nas semanas M-2, M-1 (pré-parto), M0 (dia da parição), M1, M2 e M3 (pós-parto). Foram realizadas análises das seguintes variáveis: produção leiteira, escore de condição corporal (ECC), mensuração sérica do beta-hidroxibutirato (BHB), ácidos graxos não esterificados (NEFA), IGF-1 (Fator de Crescimento Semelhante à Insulina Tipo 1), glicose (GLIC), colesterol (COL), triglicerídeos, proteína total (PT), albumina (ALB), globulina (GLOB), AST (Aspartato transaminase), GGT (Gamaglutamiltransferase) e cálcio total e cálcio ionizável. Além disso, a resposta imune celular das vacas forma avaliadas pelas interpretações do leucograma e imunofenotipagem dos linfócitos. Foram encontradas medianas do ECC equivalentes a 4,0;3,8;3,5;3,0;3,5 e 3,5 dos momentos M-2 ao M3. Em relação aos indicadores energéticos, observou-se aumento da concentração de NEFA e BHB no parto e pós-parto, ao contrário, os teores de triglicerídeos, colesterol e IGF- 1 diminuíram. Além disso, foi possível observar concentração máxima de glicose no momento da parição. Em relação ao metabolismo proteico e hepático, observam-se menores concentrações de proteína total e globulina no momento do parto; os teores de albumina diminuíram no pós-parto. A atividade sérica da AST aumentou a partir da parição, porém não foi possível detectar variações para a GGT. As concentrações de cálcio sério total e ionizado foram menores a partir da parição. A análise do leucograma das vacas no período de transição revelou leucocitose por linfocitose no momento do parto, apesar de não ter sido observada variações no número absoluto e relativo dos linfócitos durante o período de transição, foi possível observar que os linfócitos sanguíneos apresentaram-se elevados durante todo o período de estudo. O aumento no número de linfócitos decorreu da elevação dos linfócitos $B\left(C D 21^{+}\right)$. A partir desse resultado realizou-se exame sorológico para o vírus da Leucose Enzootica Bovina, detectando 12/13 (92,30\%) vacas soropositivas.
O linfócito $T$
$\left(\mathrm{CD}^{+}\right)$
e suas subpopulções
auxiliar
$\left(\mathrm{CD} 3^{+} \mathrm{CD} 4^{+}\right)$
e citotóxica 
$\left(\mathrm{CD}^{+} \mathrm{CD}^{+}\right)$apresentaram ligeiras oscilações durante o período de estudo. Com base nos resultados obtidos pode-se concluir que: a) As vacas Holandesas apresentaram variações nos parâmetros do perfil energético indicadoras de balanço energético negativo e mobilização lipídica, caracterizados especialmente pela diminuição do ECC e elevações nos teores séricos de NEFA e BHB; b) os teores de PT e GLOB apresentaram variações em decorrência da colostrogênese e infecções uterinas pós-parto. A albumina apresentou diminuição no pós-parto, decorrente do aumento da demanda nutricional para a produção de leite e uso de aminoácidos como precursor energético no processo de gliconeogênese; c) os valores de IGF-I apresentaram acentuada redução no momento do parto, sinalizando para mobilização lipídica e desacoplamento do eixo somatotrópico a partir da parição; d) as vacas apresentaram hipocalcemia, especialmente na parição e primeira semana pós-parto; e) a infecção pelo Vírus da Leucose Enzoótica Bovina influenciou na resposta imune observada no período de transição, caracterizada por linfocitose e aumento da população de linfócitos $B\left(\mathrm{CD} 21^{+}\right)$.

Palavras-chave: Balanço Energético Negativo. Bovino. Periparto. Imunofenotipagem. Proteína. Lipídio. 
ABSTRACT

BALDACIM, V. A. P. Metabolism and cellular immune response in blood of Holstein cows in the transition period. [Metabolismo e resposta imune celular no sangue de vacas Holandesas no período de transição]. 2014. 111 f. Dissertação (Mestrado em Ciências) - Faculdade de Medicina Veterinária e Zootecnia, Universidade de São Paulo, São Paulo, 2014.

The general aim of this research was to evaluate the metabolism and cellular immune response in blood of dairy cows in transition period. Was evaluated 13 Holstein cows, from $2^{\text {nd }}$ to $4^{\text {th }}$ parturitions in the weeks $M-2, M-1$ (pre-partum), M0 (parturition day), M1, M2 and M3 (post-partum). Paremeter analysis were performed: milk production, body condition score (BCS), beta-hydroxybutyrate (BHB), nonesterified fatty acids (NEFA), IGF-1 (growth factor Insulin-like similar to insulin type 1), glucose (GLUC), cholesterol ( $\mathrm{CHOL}$ ), triglycerides, total protein (TP), albumin, globulin (GLOB), AST (aspartate transaminase), GGT (gamma-glutamyl transferase), total calcium and ionized calcium. Furthermore, cows' cellular immune response was evaluated by WBC and lymphocyte immunophenotyping. Was find for BCS median 4.0; $3.8 ; 3.5 ; 3.0$; 3.5 and 3.5 between the moments $M-2$ to $M 3$. Regarding to energy indicators, an increase of NEFA and $\mathrm{BHB}$ in parturition and postpartum was observed, in contrast, the values of triglycerides, cholesterol and IGF-1 decreased. Moreover, it was possible to obtain maximum glucose concentration at parturition time. Regarding to protein and hepatic metabolic was find lower values of total protein and globulin was observed in pre-partum and parturition in relation to postpartum; values of albumin decreased in post-partum. The Aspartate aminotransferase activity increased from calving, but it was not possible to detect GGT variations. The concentration of total and ionized calcium serum were lower from calving. The analysis of cows' leukogram in the transition period revealed leukocytosis by lymphocytosis at delivery, although no variation in the absolute and relative number of lymphocytes was observed during the transition period. The increase of lymphocytes number occurred due to the increase of $B$ lymphocytes $(\mathrm{CD} 21+)$. From this result, serological test for the Enzootic Bovine Leukosis Virus was developed, detecting $12 / 13(92,30 \%)$ of seropositive cows. T lymphocytes $(\mathrm{CD} 3+)$ and subpopulations $\mathrm{T}$ helper (CD3+ CD4+) and T cytotoxic (CD3+ CD8+) showed slight fluctuations during period. Based on the results, we can conclude the following: a) Holstein cows showed variations in the parameters of the energy profile 
indicator of negative energy balance and lipid mobilization, characterized especially by the decreasing of BCS and elevations in serum NEFA and BHB; b) the levels of TP and GLOB showed variations due to colostrogenesis and postpartum uterine infections. The albumin decreased in postpartum, due to increased nutrient requeriment for milk production and use of amino acids as energy precursor in the gluconeogenesis; c) the amounts of IGF-I showed significant reduction at delivery, signaling lipid mobilization and uncoupling of the somatotropic axis after calving; d) cows showed hypocalcemia, especially in calving and first week post-partum; e) Infection with Enzootic Bovine Leukosis Virus influenced the immune response observed in the transition period, characterized by lymphocytosis and the increase of B lymphocytes $(C D 21+)$ population.

Keywords : Negative Energy Balance. Bovine. Peripartum. Immunophenotyping. Protein. Lipid. 


\section{LISTA DE TABELAS}

Tabela 1 Ocorrência de doenças da produção em vacas Holandesas no período de transição - São Paulo - 2013.

Tabela 2 - Média aritmética, desvio padrão e amplitude de variação da produção de leite diária de vacas Holandesas, da primeira a terceira semana pós-parto - São Paulo - 2013

Tabela 3 - Escore de condição corporal em vacas Holandesas no Período de transição - São Paulo - 2013.

Tabela 4 - Valores médios e medianos dos marcadores do perfil metabólico de vacas Holandesas no período de transição São Paulo - 2013

Tabela 5 - Número (N.) e frequências (\%) de vacas Holandesas no período de transição que apresentaram concentrações séricas de NEFA e BHB acima dos intervalos de referências estabelecido para vacas em lactação - São Paulo 2013.

Tabela 6 - Concentrações séricas de proteína total, albumina e globulina obtidos semanalmente a partir do soro de vacas Holandesas no período de transição - São Paulo - 2013.

Tabela 7 - $\quad$ Atividade das enzimas hepáticas AST e GGT no soro de vacas Holandesas no período de transição - São Paulo - 2013...........

Tabela 8 - Cálcio total e ionizável estimado no soro sanguíneo de vacas Holandesas no período de transição - São Paulo - 2013...........

Tabela 9 - Número (N.) e frequências (\%) de vacas Holandesas no período de transição que apresentaram valores de cálcio total $(\mathrm{mg} / \mathrm{dL})$ abaixo dos intervalos de referências estabelecido para vacas em lactação - São Paulo - 2013.

Tabela 10 - Valores de leucócitos totais, linfócitos relativos (\%) e absolutos e monócitos relativos (\%) e absolutos no sangue de vacas Holandesas no período de transição - São Paulo 2013.

Tabela 11 - Valores absolutos (células/ $\mu \mathrm{L}$ ) e proporções (\%) de células $\mathrm{CD} 21^{+}$no sangue de vacas Holandesas no período de transição - São Paulo - 2013

Tabela 12 - Valores absolutos $\left(\times 10^{3}\right.$ céls/ $\left.\mu \mathrm{L}\right)$ e proporções (\%) de linfócitos $\mathrm{T}$ e suas subpopulações auxiliar $\left(\mathrm{CD}^{+} \mathrm{CD} 4^{+}\right)$e citotóxica $\left(\mathrm{CD}^{+} \mathrm{CD}^{+}\right)$no sangue de vacas Holandesas no período de transição - São Paulo - 2013 
Tabela 13 - Resultado dos testes sorológicos (Imunodifusão em gel de Agar e Teste imunoenzimático) realizado em vacas Holandesas no período de transição - São Paulo - 2013...........

Tabela 14 - Significâncias obtidas na comparação dos ECC das vacas Holandesas entre os momentos de estudo - São Paulo - 2013

Tabela 15 - Significâncias obtidas na comparação dos marcadores do perfil energético das vacas Holandesas entre os momentos de estudo - São Paulo - 2013

Tabela 16 - Significâncias obtidas na comparação dos marcadores do perfil proteico das vacas Holandesas entre os momentos de estudo - São Paulo - 2013

Tabela 17 - Valores de P encontrado através das comparações múltiplas, pelo teste post-hoc, dos valores médios entre os tempos para cada parâmetro analisado, no sangue periférico de vacas Holandesas - São Paulo - 2013......

Tabela 18 - Significâncias obtidas na comparação dos parâmetros do cálcio total e cálcio ionizável no soro de vacas Holandesas entre os momentos de estudo - São Paulo - 2013...

Tabela 19 - Significâncias (Valor de P) obtidas na comparação dos parâmetros, pelo teste de Wilcoxon, de leucócitos totais (células $/ \mu \mathrm{L}$ ), monócitos relativo (\%) e absoluto (células $/ \mu \mathrm{L}$ ) de vacas Holandesas entre os momentos de estudo - São Paulo $-2013$.

Tabela 20 - Significâncias das subpopulações auxiliar (CD3+CD4+) no sangue de vacas Holandesas no período de transição em relação aos momentos de estudo - São Paulo - 2013. 


\section{LISTA DE FIGURAS}

Figura 1 - Representação esquemática da inter-relação do metabolismo lipídico no tecido hepático, fígado e glândula mamária.

Figura 2 Vacas triadas para avaliação do perfil metabólico e resposta imune celular no período de transição - São Paulo - 2013.

Figura 3 - Escores de condição corporal (ECC) encontrados durante a avaliação de vacas Holandesas no período de transição - São Paulo - 2013

Figura 4- Distribuição dos leucócitos sanguíneos de vacas Holandesas no período de transição: seleção dos leucócitos totais de acordo com seu tamanho (FSC) e granulosidade (SSC) (A); Seleção dos linfócitos pelo SSC (0-200) e FSC (400-600) (B); histograma da subpopulação de linfócitos $B\left(F L 1-C D 21^{+}\right)(C)$; e linfócitos T (FL3-CD3 $\left.{ }^{+}\right)(D)$ - São Paulo - 2013

Figura 5 - Subpopulações de linfócitos T CD3+CD4+ (A) e CD3+CD8+ (B) no sangue de vacas Holandesas no período de transição São Paulo - 2013

Figura 6 Média aritmética de variação da produção de leite diária de vacas Holandesas, da primeira a terceira semana pós-parto São Paulo - 2013

Figura 7 - Escore de Condição Corporal (ECC) (escala de 1 a 5) semanal no período de transição de vacas Holandesas - São Paulo 2013.

Figura 8 - Marcadores do perfil energético de vacas Holandesas avaliadas semanalmente (M-2 a M3) no período de transição: glicose (A), NEFA (B), BHB (C), Triglicerídeos (D), Colesterol (E) e IGF-I (F) - São Paulo - 2013.

Figura 9 - Frequência (\%) de vacas Holandesas que apresentaram valores de NEFA (A) e BHB (B) acima dos intervalos de referência - São Paulo - 2013.

Figura 10 - Marcadores do metabolismo proteico no soro de vacas Holandesas no período de transição, (A) Proteína Total, (B) Albumina, (C) Globulina e (D) Relação Albumina/Globulina São Paulo - 2013.

Figura 11 - Enzimas hepáticas no soro de vacas Holandesas no Período de Transição: AST (A) e GGT (B) - São Paulo - 2013.

Figura 12 - Cálcio total e ionizável no soro de vacas Holandesas no período de transição - São Paulo - 2013. 
Figura 13 - Frequências (\%) de vacas Holandesas que apresentaram hipocalcemia inaparente $(<85 \mathrm{mg} / \mathrm{L})$ no período de transição São Paulo - 2013

Figura 14 - Valores de leucócitos totais (células/ $\mu \mathrm{L})(\mathrm{A})$, linfócitos relativos (\%) (B) e absolutos (células/ $\mu \mathrm{L})(\mathrm{C})$, monócitos relativo (\%) (D) e absoluto (E) no sangue de vacas Holandesas no período de transição - São Paulo - 2013.

Figura 15 - Valores absolutos (células/ $\mu \mathrm{L}$ ) e proporções (\%) de células CD21+ no sangue de vacas Holandesas no período de transição - São Paulo - 2013

Figura 16 - Valores absolutos ( $\times 10^{3}$ céls/ $\left.\mu \mathrm{L}\right)$ e proporções (\%) de linfócitos $\mathrm{T}$ e suas subpopulações auxiliar $\left(\mathrm{CD}^{+} \mathrm{CD} 4^{+}\right)$e citotóxica $\left(\mathrm{CD} 4^{+} \mathrm{CD} 8^{+}\right)$no sangue de vacas Holandesas no período de transição - São Paulo - 2013. 


\section{LISTA DE QUADROS}

Quadro 1 - Dieta fornecida para vacas Holandesas no pré e pós-parto São Paulo - 2013

Quadro 2 - Formulação da ração fornecida às vacas Holandesas no período de transição - São Paulo - 2013.

Quadro 3 - Composição bromatológica da dieta oferecida para vacas Holandesas no pré e pós-parto - São Paulo - 2013...

Quadro 4 - Momentos das avaliações realizadas nas vacas Holandesas no período de transição - São Paulo - 2013.

Quadro 5 - Especificações dos kits comerciais utilizados nas análises bioquímicas - São Paulo - 2013.

Quadro 6 - Intervalos de referência dos parâmetros bioquímicos adotados para determinação das frequências dos distúrbios metabólicos em vacas leiteiras no período de transição São Paulo - 2013

Quadro 7 - Painel de anticorpos primários e secundários utilizados na marcação de células sanguíneas mononucleares de vacas Holandesas no período de transição - São Paulo - 2013......

Quadro 8 - Concentrações de anticorpos monoclonais primários e secundários adotadas para marcação dos leucócitos mononucleares de vacas Holandesas no período de transição - São Paulo - 2013. 
$\mathrm{AC}$

acetil-Coa Acetilcoenzima A

ACTH Hormônio Adrenocorticotrófico

AGV Ácidos Graxos Voláteis

ALB Albumina

APTA Agência Paulista de Tecnologia dos Agronegócios

AST Aspartato transaminase

BEN Balanço Energético Negativo

BHB Beta-hidroxibutirato

Ca Cálcio

$\mathrm{CRH} \quad$ Hormônio Liberador de Corticotropina

ECC Escore de Condição Corporal

EDTA Ácido Etileno Diaminotetracético

FITC Fluorescente Isothiocyanate

FMVZ Faculdade de Medicina Veterinária e Zootecnia

GGT Gamaglutamiltransferase

GH Hormônio do Crescimento

GLOB Globulina

IFN Interferon

Ig Imunoglobulina

IGF-I Fator de Crescimento Semelhante à Insulina Tipo 1

LT Linfócitos T

NDT Nutrientes Digestivos Totais

NEFA Ácidos Graxos não Esterificados 
OVA Ovalbumina

P $\quad$ Fósforo

PB Proteína Bruta

PECy5 Phycoerythrin and Cyanine

PTH Paratormônio 
LISTA DE SÍMBOLOS

$\mathrm{CO}_{2}$ Dióxido de Carbono

$\beta \quad$ Beta

kg Kilograma

g Grama

$\mu \mathrm{L} \quad$ Microlitro

үঠ் Gama Delta

G Força $G$

$\mathrm{mL} \quad$ Mililitro

${ }^{\circ} \mathrm{C} \quad$ Graus Celsius

$<\quad$ Menor

$\mathrm{NaCl}$ Cloreto de Sódio

a Alfa 


\section{SUMÁRIO}

$1 \quad$ INTRODUÇÃO

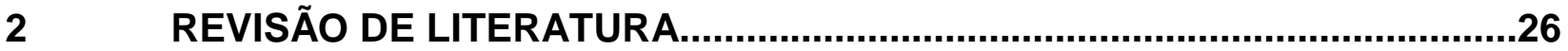

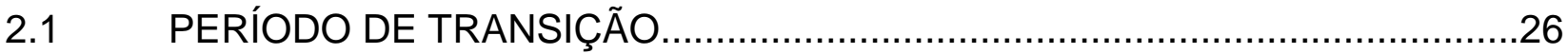

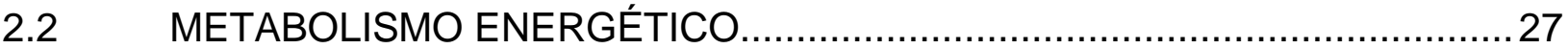

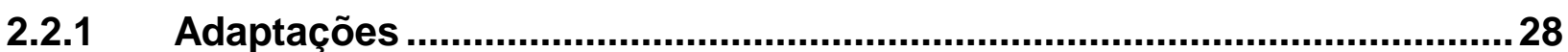

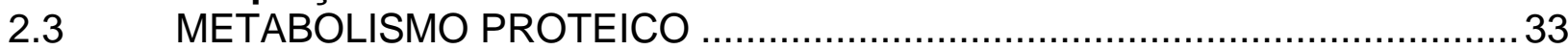

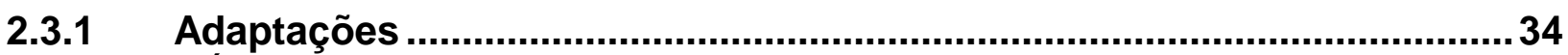

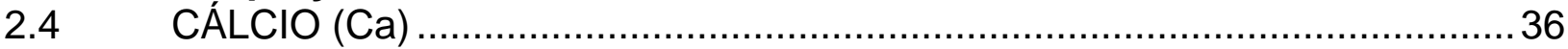

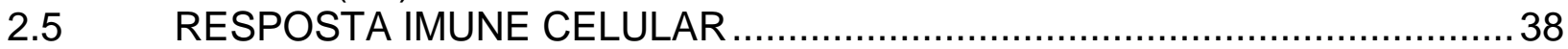

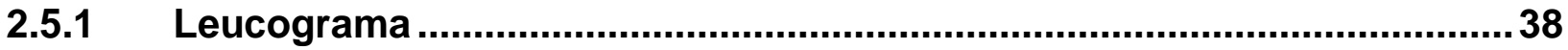

2.5.2 Subpopulações de linfócitos versus metabolismo .....................................39

3 MATERIAL E MÉTODOS …................................................................ 43

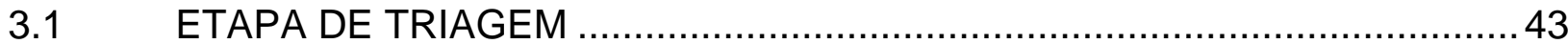

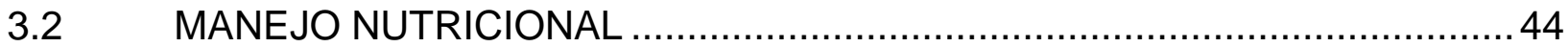

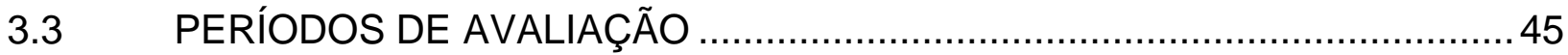

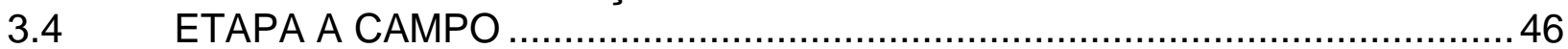

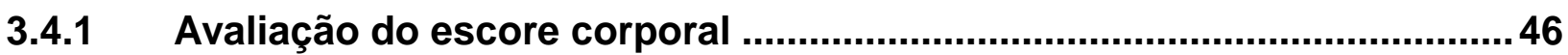

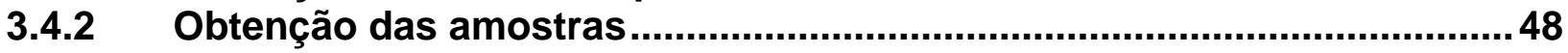

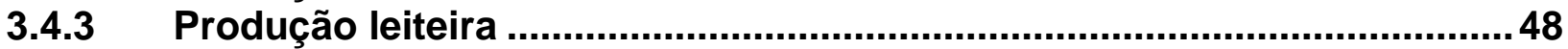

3.5 ETAPA LABORATORIAL .......................................................... 48

3.5.1 Processamento e armazenamento das amostras......................................49

3.5.2 Determinação dos parâmetros bioquímicos..............................................49

3.5.3 Interpretação do perfil metabólico .......................................................50

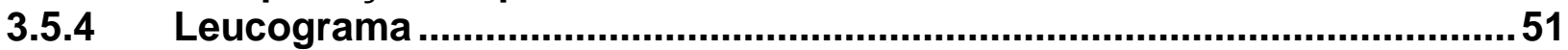

3.5.5 Imunofenotipagem dos linfócitos .....................................................51

3.5.5.1 Lise e Marcação dos Linfócitos ………………......................................52

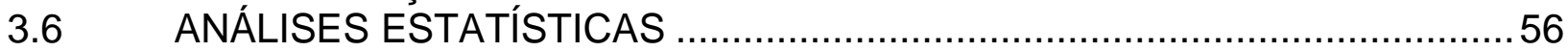

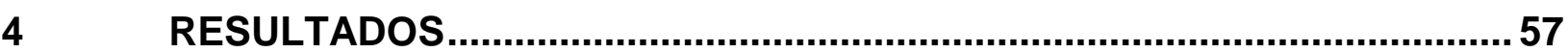

4.1 DOENÇAS DA PRODUÇÃO NO PERÍODO DE TRANSIÇÃO.......................57

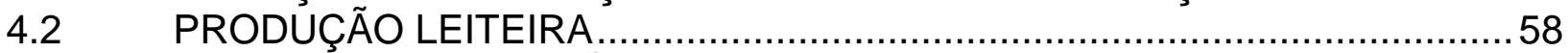

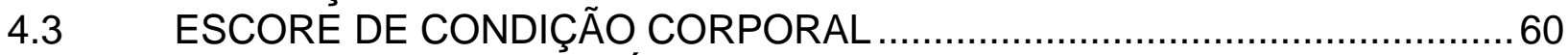

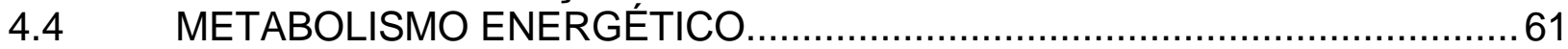

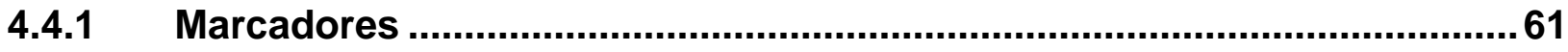

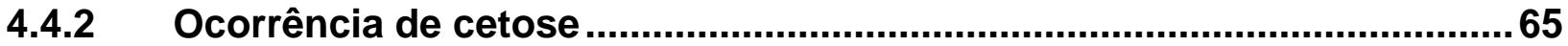

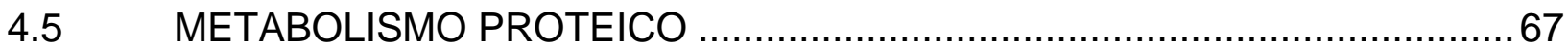

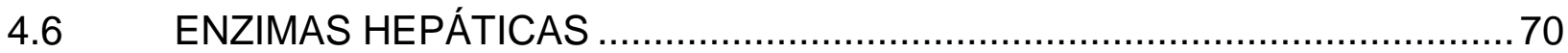

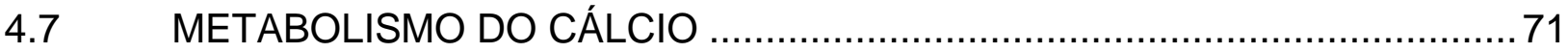

4.7.1 Ocorrência de hipocalcemia inaparente...................................................73

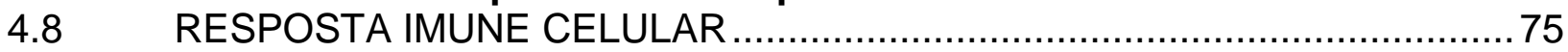

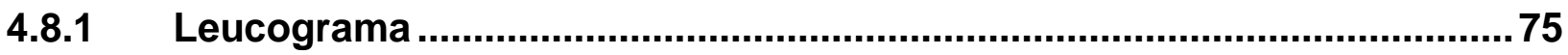

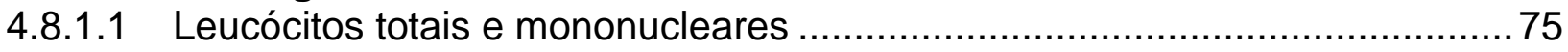

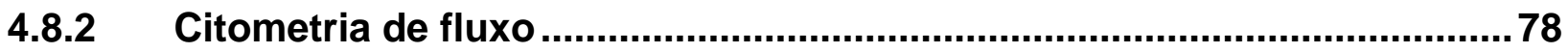

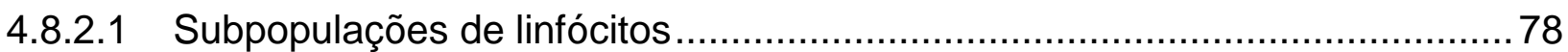

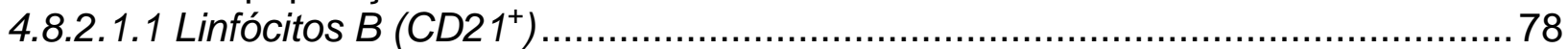

4.8.2.1.2 Linfócitos $T\left(C D 3^{+}\right)$e suas subpopulações............................................ 80 
4.9 RESPOSTA SOROLÓGICA PARA O VÍRUS DA LEUCOSE ENZOOTICA

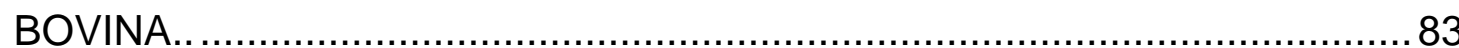

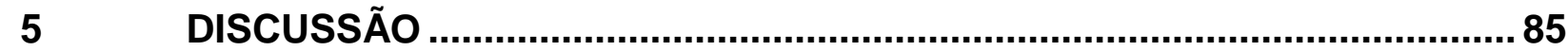

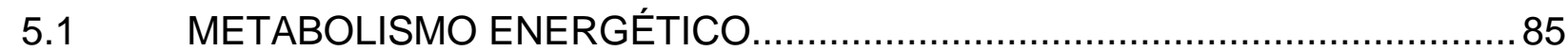

5.2 METABOLISMOS PROTEICO E HEPÁTICO ….......................................... 88

5.3 CÁLCIO

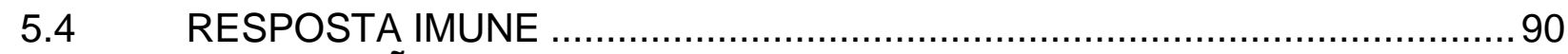

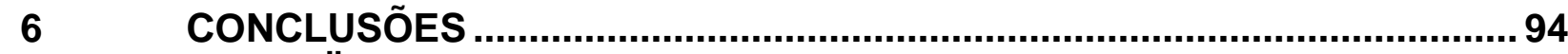

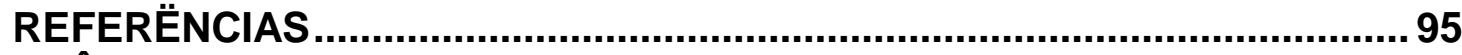

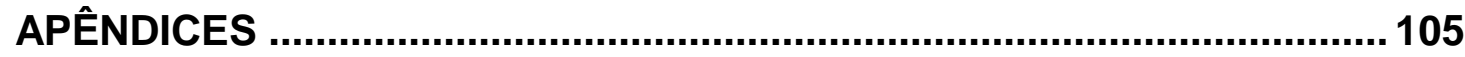




\section{INTRODUÇÃO}

O crescimento da indústria leiteira nas últimas décadas exigiu seleção genética animal para aumento da produtividade, que culminou com o aumento das demandas energéticas das fêmeas bovinas. Este fenômeno é intensificado no período de transição por mudanças ambientais, da dieta, e de socialização ocorridas, em relação aos procedimentos adotados na lactação plena (MULLIGAN; DOHERTY, 2008; INGVARTSEN; MOYES, 2013).

O período de transição é compreendido entre os 21 dias pré-parto aos 21 dias pós-parto (GRUMMER, 1995). Este período é crítico para a saúde, produção e rentabilidade dos rebanhos leiteiros (DRACKLEY, 1999).

Eventos fisiológicos de extrema importância ocorrem no período de transição, fase onde a demanda energética é aumentada para manutenção da nutrição fetal e início da lactogênese, e coincide com a redução no consumo de matéria seca em $30 \%$ (HAYIRLI et al., 2002).

A adaptação das vacas em transição é dependente de mecanismos homeostáticos e homeorréticos. Estes eventos são regulados pela secreção dos hormônios vinculados à homeorrexia de gestação, como catecolaminas, cortisol, GH, IGF-I, insulina e glucagon.

A priorização dos mecanismos homeorréticos e direcionamento dos nutrientes da dieta para a manutenção da gestação e lactogênese, em detrimento à homeostasia, podem resultar em doenças como a lipidose hepática, cetose e hipocalcemia.

No período de transição observa-se um estado temporário de balanço energético negativo (BEN), caracterizado pela diminuição da glicose sanguínea e mobilização das reservas corporais para a obtenção de energia adicional. Este processo é responsável pela elevação das concentrações séricas de ácidos graxos não esterificados (NEFA) e beta-hidroxibutirato (BHB) (DRACKLEY, 1999; BUSATO et al., 2002; KIMURA et al., 2002; ACCORSI et al., 2005; WATHES et al,. 2009). O perfil proteico também pode sofrer alterações, pois alguns aminocidos têm uma grande contribuição na gliconeogênese e podem contribuir com o fluxo da síntese d glicose, principalmente a alanina e glutamina (DRACKLEY; OVERTON; DOUGLAS, 2001). 
No periparto também ocorre aumento da demanda do cálcio para produção do colostro e leite, que pode resultar em hipocalcemia e aumento do grau de risco para deslocamento de abomaso e retenção de secundinas (GOFF et al., 2002).

O período de transição também é marcado por imunossupressão, associada às alterações metabólicas e endócrinas ocorridas nesse período. Deficiências imunológicas apresentadas aumentam o grau de risco para doenças infecciosas, como mastite e metrite (GRUMMER, 1995; MULLIGAN; DOHERTY, 2008; INGVARTSEN; MOYES, 2013).

O estudo do período de transição é fundamental para entendimento dos mecanismos homeopáticos e homeorréticos e sua relação com a resposta imune dos animais, pois a imunodeficiência apresentada é o principal fator relacionado com a lata ocorrência de doenças no período. Assim, o objetivo geral desta pesquisa foi avaliar o metabolismo e resposta imune celular no sangue de vacas leiteiras no período de transição.

Os objetivos específicos deste trabalho compreenderam:

a) A determinação do perfil energético, proteico/hepático e concentrações de cálcio sérico no sangue de vacas Holandesas no período de transição;

b) A avaliação do hormônio IGF-I no sangue de vacas Holandesas no período de transição;

c) A avaliação a resposta imune celular pelo leucograma e imunofenotipagem dos linfócitos sanguíneos: linfócitos $B\left(C D 21^{+}\right)$, linfócitos $T\left(C D 3^{+}\right)$e suas subpopulações auxiliar $\left(\mathrm{CD} 4^{+}\right)$e citotóxico $\left(\mathrm{CD} 8^{+}\right)$. 


\section{REVISÃO DE LITERATURA}

A revisão de literatura foi elaborada a partir dos principais trabalhos e pesquisas realizadas com foco nas adaptações metabólicas e imunes ocorridas no período de transição.

\subsection{PERÍODO DE TRANSIÇÃO}

O período de transição é compreendido entre os 21 dias pré-parto aos 21 dias pós-parto (VAN KAMPEN; MALLARD, 1997). Este período é crítico para a saúde, produção e rentabilidade dos rebanhos leiteiros (MULLIGAN; DOHERTY, 2008; INGVARTSEN; MOYES, 2013)

Nesse período ocorrem muitas adaptações no animal que são necessárias para a manutenção da gestação e início da lactação. Essas adaptações ao novo estado fisiológico e condições nutricionais do período de transição das vacas leiteiras ocorre por meio de mecanismos homeostáticos e homeorréticos.

O controle homeostático envolve manutenção do equilíbrio fisiológico. Já a homeorrexia pode ser definida como o controle orquestrado ou controlado no metabolismo dos tecidos corporais necessários para suportar um novo estado fisiológico (BAUMAN; CURRIE, 1980). Apesar do novo estado também ser fisiológico, as adaptações podem refletir negativamente em alguns aspectos nutricionais, metabólicos e imunes das vacas leiteiras.

No perido de transição observa-se intensa diminuiç ão na ingestão de matéria seca, especialmente na ultima semana que antecede a parição (HAYIRLI et al., 2002). Este fato, associado ao aumento na demanada de energia geralmente resulta em deficiencia energética, o que resultada em mobilização de tecido adiposo, com consequente elevação do NEFA e BHB devido ao BEN, podendo resultar em lipidose hepática e cetose (DRACKLEY, 1999; BRUSS, 2008).

Altos teores de NEFA e BHB, assim como menores concentrações de cálcio na semana pré e pós-parto estão associadas com deslocamento de abomaso, diminuição na produção de leite e redução na taxa de prenhez na primeira 
inseminação (CHAPINAL et al., 2012b). Além disso, altas concentrações de NEFA uma semana antes do parto estão associados com aumento do risco de metrite e retenção de placenta (CHAPINAL et al., 2011).

A imunossupressão relatada no período de transição, que pode estar associada às alterações metabólicas e endócrinas aumentam o grau de risco às doenças infecciosas, como mastite e doenças reprodutivas (GRUMMER, 1995; MULLIGAN; DOHERTY, 2008; INGVARTSEN; MOYES, 2013).

\subsection{METABOLISMO ENERGÉTICO}

A glicose é a principal fonte de energia para os tecidos, especialmente 0 nervoso. As principais fontes de glicídeos nos ruminantes são celulose, hemicelulose e pectinas e, em menor proporção, amido e dissacarídeos. Ruminantes praticamente não absorvem glicose no trato gastrintestinal, pois ela é completamente fermentada em ácidos graxos voláteis no rúmen (GONZÁLEZ; SILVA, 2006).

Celulose e outros glicídeos estruturais das paredes celulares (polissacarídeos) dos vegetais são fermentados por microrganismos do ambiente ruminal em ácidos graxos voláteis de cadeia curta (AGV), especialmente ácido acético, propiônico e butírico. Os produtos da fermentação anaeróbia são absorvidos diretamente na parede do rúmen e, em menor proporção no retículo, omaso e intestino grosso, para serem transportados ao fígado. No epitélio ruminal os AGV são absorvidos e sofrem metabolização: $80 \%$ do butirato é convertido em acetoacetato e BHB (corpos cetônicos); e $50 \%$ do propionato pode ser metabolizado em lactato ou piruvato (GONZÁLEZ; SILVA, 2006). O restante do ácido propiônico absorvido é transformado em glicose no fígado por meio da gliconeogênese (REYNOLDS et al., 1988; CORREA; GONZÁLEZ; SILVA, 2010).

A gliconeogênese hepática pode ser realizada por várias vias bioquímicas, dependendo dos precursores da glicose. Nos ruminantes, a fonte primária de glicose é o propionato, porém existem outros precursores da gliconeogênese, como o glicerol obtido a partir da lipólise; o lactato oriundo da glicólise anaeróbica no músculo esquelético; e os aminoácidos originários da proteólise (GONZÁLEZ; SILVA, 2006). 
Concentrações plasmáticas elevadas de glicose resultam em glicogenêse, sob influencia da insulina e inibição do glucagon. Este processo ocorre no citosol das células de todos os tecidos, especialmente no fígado e músculos esqueléticos, locais de estoque do glicogênio. Ao contrário, o aumento da demanda energética estimula a glicogenólise, no qual o glicogênio hepático é degradado em glicose, fonte para o processo oxidativo e formação de energia. Este processo é regulado pelas catecolaminas e glucagon que atuam diretamente no fígado e músculos (GONZÁLEZ; SILVA, 2006).

Adaptações orgânicas mediante aumento ou diminuição da demanda de energia são dependentes das vias metabólicas destacadas.

\subsubsection{Adaptações}

No período de transição observa-se aumento da demanda energética de duas a três vezes, quando comparado aos demais períodos fisiológico, do $21^{\circ}$ dia préparto ao $21^{\circ}$ dia pós-parto, que excede o potencial de ingestão, resultando em balanço energético negativo (BEN). Na demanda por energia, o glucagon é liberado e estimula a lipólise, que promove a hidrólise de triglicerídeos e libera ácidos graxos não esterificados (NEFA) e glicerol. Estes dois componentes alcançam o fígado pela corrente sanguínea, em seguida, o glicerol pode ser utilizado na produção de glicose (gliconeogênese), ou pode ser combinado novamente ao NEFA para recomposição da molécula de triglicérides (BRUSS, 2008).

Essas adaptações que culminam no BEN e consumo das reservas corpóreas dos animais são visivelmente notadas pela diminuição do ECC.

Busato et al. (2002) estudaram a perda do ECC em vacas Holandesas saudáveis. Estes autores que animais com ECC maior do que 3,25 no pré-parto apresentam cetose inaparente e maiores riscos de problemas metabólicos devido à excessiva mobilização da reserva de energia corpórea.

Hayirli et al. (2002) estudaram 49 diferentes dietas em 699 vacas Holandesas durante as três semanas finais da gestação, compiladas de 16 experimentos realizados na década de 90 . Foram avaliados diariamente o consumo de matéria seca, peso corporal e ECC. Os animais foram classificado como magros (ECC 1 a 
3), médios ( $E C C$ 3,01 a 4) e obesos (ECC 4,01 a 5). Os autores verificaram uma diminuição de $40 \%$ no consumo de matéria seca nos animais gordos versus 28 e $29 \%$ nos animais magros e médios, respectivamente da $3^{\text {a }}$ semana pré-parto ao parto, se acentuando na última semana pré-parto.

Mouffok et al. (2013) verificaram redução do ECC de 3,04 nas semanas préparto para 2,77 nas semanas pós-parto, e verificaram correlação negativa entre ECC com valores de BHB.

Lago et al. (2001) encontraram perda de peso mais intensas e valores maiores de $\mathrm{BHB}$ em vacas holandesas obesas $(E C C \geq 4,0)$ quando comparado com vacas de $E C C$ menor $(E C C \leq 3,5)$, as concentrações de BHB foram maiores na primeira e segunda semana pós-parto e os autores concluiram que esses animais apresentaram BEN mais intenso, considerando que os teores de glicose foram menores no grupo de animais obesos.

No periparto, os teores séricos do NEFA e BHB são indicadores úteis da capacidade das vacas para lidar com os desafios metabólicos no período de transição, eles medem a mobilização e oxidação de gordura, respectivamente, e refletem o sucesso da vaca na adaptação ao balanço energético negativo (HERDT, 2000; ARAUJO, 2009). No momento do parto ocorre a elevação das concentrações plasmáticas desses indicadores (HAMMON et al., 2009; MOREIRA, 2013).

LeBlanc et al. (2005) verificaram que altas concentrações de NEFA $(\geq 0,4 \mathrm{mmol} / \mathrm{L})$ de 10 à 7 antes do parto está associado com o aumento do risco de deslocamento de abomaso, retenção de placenta e queda na produção de leite. Duffield et al. (2009) relatou que valores superiores de BHB (>1200 mmol/L) na primeira ou segunda semana pós-parto está associada com risco aumentado de deslocamento de abomaso e metrite.

Os NEFA são absorvidos pelo fígado e no processo de oxidação é reduzido a dois carbonos e convertido em acetil-Coa (acetilcoenzima A), e na presença do oxaloacetato ingressa no ciclo do ácido cítrico (Ciclo de Krebs), onde é submetido a uma série de reações, gerando energia e $\mathrm{CO}_{2}$. $\mathrm{Na}$ ausência de quantidades suficientes de oxaloacetato, o acetil-Coa é desviado para outras vias metabólicas, sendo transformado em acetato, precursor dos corpos cetônicos como o betahidroxibutirato (BHB) e acetona (BEITZ, 1996). Corpos cetônicos podem ser utilizados como fonte de energia em outros tecidos extra-hepático, em especial coração e rins (DRACKLEY, 1999). 
No balanço energético negativo observa-se déficit energético, grande mobilização de tecido lipídico e elevação da produção de Acetil-CoA. Assim, a produção e consumo de corpos cetônicos impede o acúmulo do acetil-CoA e feed back negativo para o processo de oxidação dos ácidos graxos, favorecendo a formação de corpos cetônicos (GONZÁLEZ; SILVA, 2006).
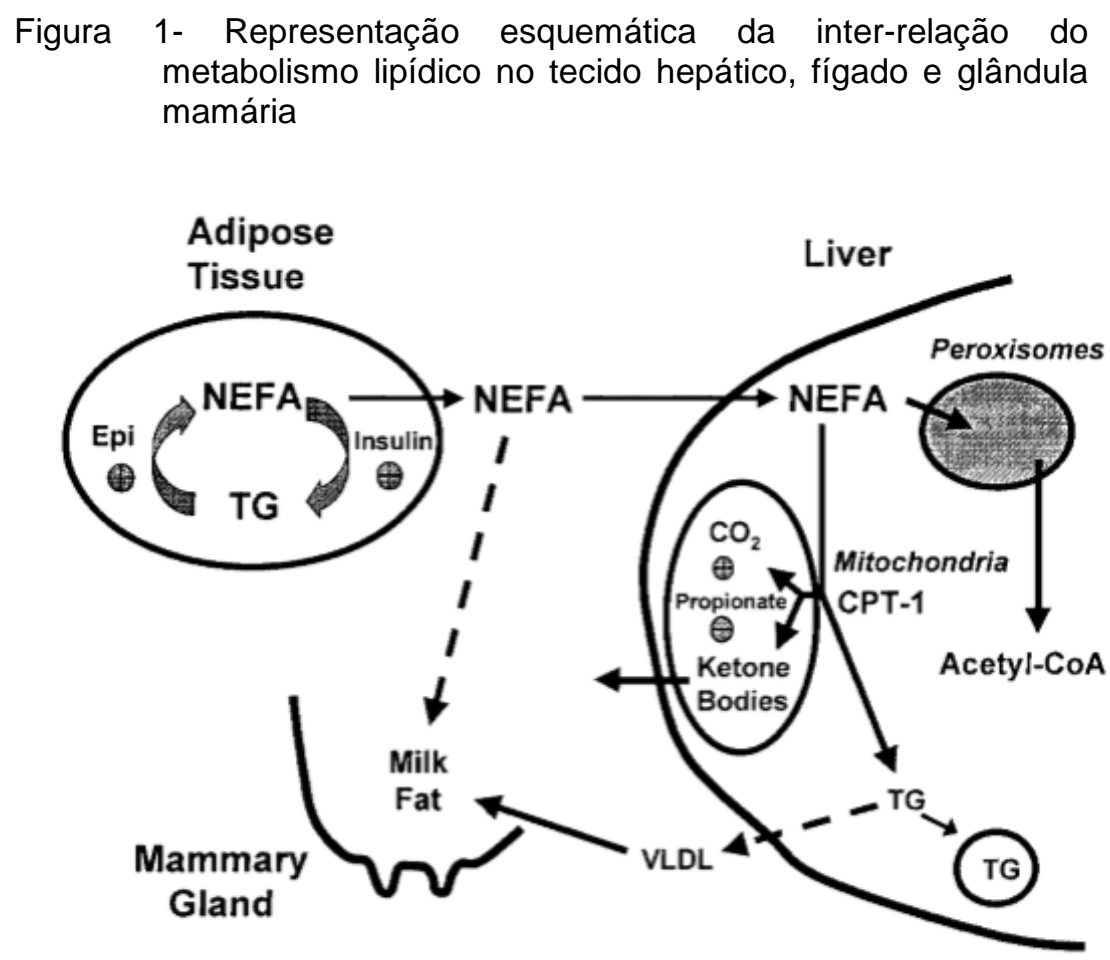

Fonte: (DRACKLEY, 1999)

Legenda: Sinal positivo (+) efeito estimulatório; Sinal negativo (-) efeito inibitório. Linhas tracejadas indicam que o processo ocorre em baixas concentrações ou somente durante certos estágios fisiológicos. Abreviações: Epi = epinefrina; $\mathrm{TG}=$ triglicerídeos; VLDL = lipoproteínas de baixa densidade.

Cincovic et al. (2012) examinaram as características do perfil metabólico e leucograma em vacas no periparto com base na intensidade da lipólise (elevação de NEFA) e cetogenese (elevação BHB). Baseados nos concentrações médios de NEFA $(0,27 \mathrm{mmol} / \mathrm{L}$ e $0,61 \mathrm{mmol} / \mathrm{L})$ e BHB $(0,51 \mathrm{mmol} / \mathrm{L}$ e $0,99 \mathrm{mmo} / \mathrm{L})$ uma semana pré e uma semana pós-parto, respectivamente, dividiram os animais em 3 grupos: a) controle: concentrações de NEFA e BHB abaixo dos valores medianos no pré e pósparto; b) com catabolismo fisiológico: concentrações de NEFA e BHB inferiores no 
pré-parto e, NEFA e BHB superiores no pós-parto; c) com catabolismo acima do fisiológico: concentrações de NEFA e BHB superiores no pré e pós-parto. Os animais foram avaliados na última semana antes de parto, e primeira, segunda, quarta e oitava semana pós-parto. De uma maneira geral foi possível observar maiores concentrações de NEFA e BHB, menores concentração de glicose, colesterol, proteina total, aumento nos teores de AST e ALT, menores valores de cálcio, menor contagem de leucócitos e maior numero de linfócitos nos dois grupos apresentando NEFA e BHB altos, em relação ao controle. Portanto, os autores concluíram que a lipólise (elevação do NEFA) e cetogenese (elevação de BHB) tiveram influencia significativa no perfil metabólico e contagem sanguíneo nas vacas durante esse período.

Alterações endócrinas vinculadas à homeorrexia e gestação interferem no metabolismo energético.

O estresse das vacas no periparto desencadeia um importante mecanismo endócrino que controla os teores de glicose, que são mediadas pela ativação do eixo somatotrópico que resulta na liberação de catecolaminas (epinefrina e norepinefrina) e cortisol, estimulam o sistema nervoso simpático, resultando na lipólise que aumenta a mobilização do NEFA a partir do tecido adiposo e estimula a gliconeogênese (GRUMMER, 1995; DRACKLEY, 1999)

O cortisol materno e fetal é produzido pela ativação do eixo somatotrópico. Os mecanismos endócrinos envolvidos são controlados pela produção aumentada de hormônio liberador de corticotropina $(\mathrm{CRH})$ pelo hipotálamo, que por sua vez, atua na glândula adeno-hipófise aumentando o hormônio adrenocorticotrófico (ACTH), e esse por fim, atua na glândula adrenal produzindo o cortisol (JACKSON, 2006).

As concentrações de glicocorticóides começam a aumentar três dias antes do parto, observando-se pico no parto e retorno aos intervalos de referência no terceiro dia pós-parto. $\mathrm{O}$ corticóide possui efeito hiperglicemiante por estimular a lipólise e proteólise. $O$ cortisol promove expressão de enzimas hepáticas para gliconeogênese a partir de precursores como aminoácidos e glicerol (GOFF; KEHRLI; HORST, 1989; PATEL et al., 1996).

Os teores de cortisol aumentam de $20 \mathrm{pg} / \mathrm{mL}$ no início da gestação, para picos entre 4000 e $6000 \mathrm{pg} / \mathrm{mL}$ nos momentos antes do parto (CHEW et al., 1977). O cortisol possui efeito hiperglicemiante (PATEL et al., 1996). 
O eixo somatotrópico também controla a liberação do hormônio do crescimento (Growth Hormone - GH) pelo hipotálamo (GUYTON, 2008). O GH, o receptor para hormônio do crescimento no fígado (GHR) e o fator de crescimento semelhante à insulina tipo 1 (Insulin-like Growth Factor - IGF-I), regulam eventos metabólicos em vacas no período de transição. $\mathrm{O}$ GH aumenta os estímulos lipolíticos, atenuando a resposta lipogênica da insulina e inibe a captura de glicose pelos adipócitos. Além disso, promove a síntese hepática do IGF-I, responsável pelo aumento da captação de glicose pelas células do organismo. No entanto, vacas no início de lactação podem apresentar desacoplamento do eixo somatotrópico, caracterizado pela resistência hepática ao GH e diminuição da síntese hepática de IGF-I, que corrobora para a manutenção do BEN no período de transição (LANG; FROST, 2002).

Em vacas de alta produção, o GH encontra-se elevado, e a concentração do IGF-I está reduzida em $70 \%$ no pós-parto imediato e aumenta gradualmente em concomitância com a expressão de receptores hepáticos para GH (TAYLOR et al., 2004). O IGF-I pode ser usado como indicador do estado nutricional e fisiológico da vaca, pois não possui influência do ciclo circadiano e momento da alimentação (RONGE et al., 1988). Hammon et al. (2009), Laeger et al. 2014 e Nowak et al 2014 avaliariam os teores séricos de IGF-I no período de transição e observaram nos dias entorno do parto diminuição de aproximadamente $56 \%$ do dia -20 ao dia 1 do parto e 87.5\% (LAERG et al., 2014) e 89\% do dia -30 ao dia + 5 em relação ao parto. O IGFI pode ser usado como indicador do estado nutricional e fisiológico da vaca, pois não possui influência do ciclo circadiano e momento da alimentação (RONGE et al., 1988).

Hipoinsulinemia decorrente da diminuição na produção de insulina pelo pâncreas, e diminuição da resposta à insulina são mecanismos homeorréticos presentes no periparto (BELL; BAUMAN, 1997; DRACKLEY; OVERTON; DOUGLAS, 2001). Isso possibilita que haja maior disponibilidade de glicose para o feto e glândula mamária, tecidos insulina independentes, enquanto que os outros tecidos passam a utilizar corpos cetônicos para suprir suas necessidades energéticas (BELL, 1995). Fontes de energia alternativas são assim necessárias para determinados tecidos do organismo, a fim de manter a função normal durante este período de aumento da produção de leite (McART et al., 2013). 
A resistência à insulina ocorre pela intensidade dos eventos bioquímicos hiperglicemiantes decorrentes dos altos teores de glucagon, catecolaminas (noradrenalina e epinefrina), GH e cortisol no periparto.

A coordenação do metabolismo lipídico entre tecido adiposo, hepático, intestinos e glândula mamária é a chave para a adaptação à lactação (DRACKLEY, 1999).

Essa mobilização intensa das reservas corpóreas resulta na perda de peso, queda na produção de leite e aumento do risco das doenças da produção.

\subsection{METABOLISMO PROTEICO}

Nos ruminantes, as proteínas da dieta são degradadas até aminoácidos, que são reutilizados pelas bactérias presentes no ambiente ruminal. Os aminoácidos produzidos são degradados em amônia ou fermentados em AGV. Além das proteínas, as bactérias do rúmen podem utilizar fontes de nitrogênio não-proteico (amônia, nitratos, amidas) como precursores para a formação de novos aminoácidos (GONZÁLEZ; SILVA, 2006).

A ureia no rúmen é hidrolisada por enzimas bacterianas liberando amônia e $\mathrm{CO}_{2}$. A amônia é utilizada pelas bactérias como substrato para formação de aminoácidos e síntese de proteína bacteriana. O excesso de amônia será direcionado para o fígado pelo sistema porta, local onde será metabolizada no ciclo da uréia. A uréia produzida será excretada urina, ou poderá ser reciclada para o rúmen vias sanguínea ou salivar (GONZÁLEZ; SILVA, 2006).

A proteína microbiana é digerida no abomaso e a absorção de aminoácidos ocorre no duodeno e jejuno (GONZÁLEZ; SILVA, 2006). Também podem contribuir na produção de energia do organismo, por meio da degradação de aminoácidos com destino à oxidação. A degradação dos aminoácidos libera amônia que deve ser rapidamente metabolizada devido à sua toxicidade, seja pela incorporação de outros aminoácidos ou na forma de uréia. $O$ excedente dos aminoácidos produzidos, que não são utilizados na gliconeogênese, sofre proteólise endócrina (GONZÁLEZ; SILVA, 2006). 
Quando ocorre a degradação oxidativa, cada aminoácido passa por uma via metabólica específica, porém todas convergem para a produção de piruvato, acetilCoA ou compostos intermediários do ciclo de Krebs. O catabolismo dos aminoácidos ocorre principalmente no fígado e em menor parte nos rins, e não é uma via tão ativa quanto à glicólise ou a oxidação dos ácidos graxos. As rotas catabólicas variam em sua atividade dependendo das necessidades energéticas ou biossintética do organismo (GONZÁLEZ; SILVA, 2006).

\subsubsection{Adaptações do metabolismo proteico}

O músculo esquelético é um reservatório aminoácidos durante o período de transição (Bell, 1995). Os aminoácidos desempenham papel particularmente importante no aumento da gliconeogênese durante o inicio da lactação (BELL; BURHANS; OVERTON, 2000). A importância evidente dos aminoácidos glicogênicos como precursores de glicose durante o periparto imediato demonstra a necessidade de quantificar fornecimento de proteína e utilização metabolizável por estes animais (DRACKLEY; OVERTON; DOUGLAS, 2001).

No período de transição, os aminoácidos têm uma grande contribuição na gliconeogênese. Os aminoácidos, exceto leucina e lisina (cetogênicos), podem contribuir com o fluxo da síntese de glicose, principalmente a alanina e glutamina. Há correlação positiva entre a glicose plasmática e a proteína ingerida (DRACKLEY; OVERTON; DOUGLAS, 2001).

Aminoácidos desempenham papel particularmente importante no aumento da gliconeogênese durante o início da lactação (BELL; BURHANS; OVERTON, 2000). Bell (1995) postulou que o músculo esquelético é um reservatório instável de aminoácidos durante o período de transição. Simmons et al. (1994) reportaram que o músculo serve como pool proteico no início da lactação.

Alterações no proteinograma de vacas no período de transição também podem ocorrer devido à colostrogênese, processo que se inicia semanas antes do parto. Neste processo, observa-se a transferência da $\lg \mathrm{G} 1$ da circulação sanguínea para o colostro mediada por receptores específicos para essa imunoglobulina (BUTLER, 1983). A IgG1 se liga ao seu receptor específico (porção Fc), localizado 
na superfície basi-lateral das células epiteliais alveolares (KEMLER et al., 1975), observando endocitose, transporte da lgG1 pelas células em vesículas e liberação dessa imunoglobulina na superfície apical da glândula mamaria (BUTLER, 1983; LARSON, 1985). A classe de imunoglobulinas predominante no colostro e leite bovino é a IgG1 (até 90\%) (LARSON, 1992; BARRINGTON et al., 1997).

A classe de imunoglobulinas predominante no colostro e leite bovino é a IgG1 (até 90\%) (LARSON, 1992; BARRINGTON et al., 2001), contrastando com as baixas concentrações das classes IgA e IgM (BARRINGTON et al., 2001). Além disso, Sordillo et al. (1987) verificaram que a albumina sérica apresentou-se aumentada da parição ao $7^{\circ}$ dia pós-parto.

Samanc et al. (2011) realizou estudo para examinar a possibilidade de utilizar os resultados do teste de perfil metabólico na predição e diagnóstico de esteatose hepática em vacas da raça Holandesa no periodo de transição, assim as concentrações de alguns dos marcadores mensurados foram, glicose, BHB, proteína total, albumina e cálcio. Através de biopsia hepática realizada 12 dias pós-parto, classificaram os animais saldáveis e com esteatose hepática. Analisando os dados observaram que: as concentrações BHB foram significativamente maiores nas vacas doentes; a concentração de glicose foi significativamente menor nos animais acometidos; trinta dias pós-parto, as concentrações de albumina, glicose, BHB e Ca eram significativamente mais baixos em vacas com esteatose. Assim o autor conclui que alterações importantes no metabolismo hepático, proteico e energético podem ser diretamente influenciados pela saúde hepática.

Atividades séricas das enzimas AST e GGT aumentada auxiliam no diagnóstico de alterações hepáticas (KANEKO, 2008). Moreira (2013) encontrou durante o periparto de vacas holandesas aumento nos teores de AST e GGT parto e pós-parto, essas concentrações ficaram inferiores aos valores de referencia (KANEKO, 2008). Durante este período devido a demanda energética, para suprir a síntese láctea, o fígado aumenta sua atividade no processo de gliconeogenêse que resulta na elevação desses marcadores (Seal; Reynolds, 1993).

Outra ferramenta importante no auxilio do diagnóstico de doenças hepáticas é a relação albumina:globulina. Lesões hepáticas crônicas resultam na queda dos teores de albumina e aumento de globulina, o valor critico para saúde hepática é na taxa inferior a 0,5 (BIRGEL JUNIOR et al.,2003). 


\subsection{CÁLCIO (Ca)}

O cálcio orgânico encontra-se depositado no esqueleto (90\%) na forma de fosfato de cálcio. $O$ restante participa da manutenção das funções vitais, e encontrase nos fluídos corporais na forma ionizada $\left(\mathrm{Ca}^{2+}\right)$ (GUYTON, 2008). A principal função do cálcio é a contração muscular, porém estudos têm demonstrado que a sinalização intracelular do cálcio é um recurso inicial muito importante para a ativação do sistema imune (KIMURA; REINHARDT; GOFF, 2006).

No sangue de uma vaca adulta existe cerca de 8 à $10 \mathrm{mg} / \mathrm{dL}$ de Ca. As vacas perdem em média $20 \mathrm{~g}$ a $30 \mathrm{~g}$ de Ca por dia via colostro ou leite produzido, e 5,5 à 9 $\mathrm{g}$ de Ca por dia pelas fezes e urina. Para evitar a hipocalcemia, que resulta em consequências graves para os processos vitais, a vaca deve suprir a perda de $\mathrm{Ca}$ decorrente da lactogenese, através da reabsorção intestinal ou óssea (GOFF, 2000).

O metabolismo do cálcio é regulado por dois hormônios calcitrópicos: o paratormônio (PTH) secretado a partir da paratireóide; e a vitamina $D_{3}(1,25$ dihidroxivitamina $D$ ), metabólito da vitamina $D$ produzido nos rins (HORST, 1986). O PTH estimula a síntese renal da vitamina $D_{3}$, que aumenta a atividade e reabsorção óssea pelos osteoclastos, no entanto, sua função mais importante é a absorção de $\mathrm{Ca}$ via intestinal. Além disso, a vitamina $\mathrm{D}_{3}$ estimula as proteínas ligantes do cálcio que carreiam esse mineral através das células intestinais, e a atividade da CaATPase magnésio dependente, que bombeia o cálcio das células intestinais para a circulação (CORREA; GONZÁLEZ; SILVA, 2010).

O cálcio presente nas fezes, urina, leite, feto e osso é 35 a 100 vezes maior do que o encontrado no sangue circulante (RAMBERG; KRONFELD; WILSON, 1975; GRACE, 1981). O fornecimento de cálcio para os pools ocorre por absorção intestinal e reabsorção óssea, por influência hormonal (HORST; GOFF; REINHARDT, 1994).

Dentre os fatores que afetam o metabolismo do cálcio podemos citar a alimentação com quantidade reduzida de vitamina $D$, que resulta em menor absorção de Ca intestinal (HIBBIS; CONRAD, 1983).

Durante o início da lactação, a resposta absortiva de Ca e P (fósforo) do osso é um tanto refratária ao estímulo do PTH e vitamina $D_{3}$. Nesta fase, a vaca depende principalmente do $\mathrm{Ca}$ absorvido do intestino, verificando que a reabsorção óssea 
desempenha um papel muito menor até a 1-2 semanas pós-parto (RAMBERG et al., 1984; HORST, 1986).

Horst (1986) afirmou que da parição (dia 0) à $5^{\text {a }}$ semana pós-parto ocorre um aumento das necessidades de $\mathrm{Ca}$, de $+/-125 \mathrm{~g} /$ dia para $+/-160 \mathrm{~g} / \mathrm{dia}$, para manter a lactação, observando-se diminuição progressiva nas semanas subsequentes.

Se o organismo é incapaz de suprir a súbita demanda de cálcio observa-se evolução para a hipocalcemia moderada ou severa, que é considerada uma das mais comuns doenças da produção associadas com parto ou início da lactação (HORST, 1986; GOFF, 2008; REINHARDT et al., 2011).

A maior frequência de hipocalcemia é dentro das primeiras 24h pós-parto, e acomete principalmente vacas com maior número de lactação (ORTOLANI, 1995). Moreira (2013) encontrou menor valor sérico de Ca no momento do parto $(8,7 \mathrm{mg} / \mathrm{dL})$.

Durante o início da lactação, a resposta absortiva de Ca e P (fósforo) do osso é um tanto refratária ao estímulo do PTH e vitamina $D_{3}$. Nesta fase, a vaca depende principalmente do $\mathrm{Ca}$ absorvido do intestino, verificando que a reabsorção óssea desempenha um papel muito menor até a 1-2 semanas pós-parto (RAMBERG et al., 1984; HORST, 1986). Caso as concentrações de cálcio na dieta não forem suficientes para suprir as exigências fisiológicas, o animal precisa utiliza suas reservas, esse mecanismo compensatório é regulado pelo PTH, que em alguns casos não são sintetizados em tempo e concentração suficiente para elevar os valores de cálcio circulante e suprir sua demanda. A fim de contornar esse problema, as dietas aniônicas de cálcio tem por finalidade "antecipar" a utilização de cálcio das reservas óssea no pré-parto, para que no parto e inicio da lactação as concentrações de PTH sejam adequadas para a manutenção das concentrações do cálcio (VAGNONI; OETZEL, 1998).

Estudos de Curtis et al. (1983) demonstraram que a hipocalcemia pode reduzir a vida reprodutiva de uma vaca de leite em três a quatro anos. Nesta pesquisa, foi observado também que vacas com hipocalcemia tiveram três a nove vezes maior grau de risco para apresentar outras doenças no período pós-parto como a distocia, cetose, mastite e retenção de placenta. Além disso, a hipocalcemia tem sido associada com a ocorrência de deslocamento de abomaso (CURTIS et al.,1983; MASSEY et al.,1993; CORASSIN, 2004), menor taxa de prenhez à primeira inseminação artificial, e menor produção de leite (CHAPINAL et al., 2012). 
Corassin (2004) estudando rebanho leiteiro no Estado de São Paulo que vacas multíparas e com retenção de placenta apresentaram maior incidência de hipocalcemia que vacas primiparas.

O cálcio intracelular é fundamental para a regulação da proliferação celular, produção de citocinas e expressão do receptor de citocinas (PARTISETI et al., 1994). Estoque de cálcio intracelular reduzido nas células imunes, pode contribuir para a imunossupressão observada no período de transição (KIMURA; REINHARDT; GOFF, 2006)

\subsection{RESPOSTA IMUNE CELULAR}

Serão apresentados nesta sessão dados de literatura referentes à imunidade celular e sua transição.

O desencadeamento da imunossupressão das vacas em transição tem sido atribuído às variações metabólicas e hormonais ocorridas nesse período, no entanto, esse complexo de respostas envolve a atuação de uma série de hormônios e substâncias que podem ser a chave para a ativação da resposta imune (MALLARD et al., 1998; INGVARTSEN et al., 2003; MEGLIA et al., 2005; LOISELLE et al., 2009).

\subsubsection{Leucograma}

A resposta leucocitária de vacas em transição pode ser usada como indicativo de estresse e bem-estar animal (DAVIS; MANEY; MAERZ, 2008). O estresse resulta na liberação de glicocorticóides e padrão leucocitário típico, caracterizado por leucocitose, neutrofilia, monocitose, linfopenia e eosinopenia.

O perfil sanguíneo de vacas leiteiras no periparto foi estudado por Meglia et al. (2005). Dez vacas foram acompanhadas, realizando-se avaliações em três momentos distintos: 30 dias antes (M-1) e após (M1) o parto previsto e na parição (M0). Foi possível notar um aumento no valor absoluto dos leucócitos totais no 
momento do parto $\left(8,7 \times 10^{3} / \mu \mathrm{L}\right)$ em relação ao $\mathrm{M}-1\left(6,3 \times 10^{3} / \mu \mathrm{L}\right)$ e $\mathrm{M} 1\left(7,2 \times 10^{3} / \mu \mathrm{L}\right)$. Oscilação semelhante aos leucócitos foi observada para os neutrófilos e monócitos, observando-se valores de 2,3 e $0,5 \times 10^{3} / \mu \mathrm{L}$ no $\mathrm{M}-1 ; 4,7$ e $1,3 \times 10^{3} / \mu \mathrm{L}$ no $\mathrm{M0}$ e 3,1 e $0,7 \times 10^{3} / \mu \mathrm{L}$ no $\mathrm{M} 1$, respectivamente. Os linfócitos não oscilaram entre $\mathrm{M}-1$ (2,8 $\left.x 10^{3} / \mu \mathrm{L}\right), \mathrm{M} 0\left(2,2 \times 10^{3} / \mu \mathrm{L}\right)$ e $\mathrm{M} 1\left(2,6 \times 10^{3} / \mu \mathrm{L}\right)$, porém foi possível detectar pequena diminuição dos seus valores no M0. Kim; Na; Yang (2005) também observaram leucocitose por neutrofilia e monocitose no momento da parição, porém não observaram oscilações nos valores de linfócitos entre os momentos avaliados.

Nagahata et al. (1992) e Detilleux et al. (1995) avaliaram a resposta leucocitária no período de transição e observaram diminuição nos valores de linfócitos do pré-parto até as duas semanas pós-parto, inclusive no momento da parição.

\subsubsection{Subpopulações de linfócitos versus metabolismo}

No periparto observa-se diminuição na população de linfócitos $T\left(C D 3^{+}\right)$e suas subpopulações $\mathrm{CD}^{+}$(auxiliar) e $\mathrm{CD}^{+}$(citotóxico) próximo a parição (KIMURA et al., 1999). A resposta imune celular em vacas com processo inflamatório no periparto é menor que àquela observada em animais hígidos (OHTSUKA et al., 2004).

Ohtsuka et al. (2010) comparando quatro grupos de animais saudáveis de rebanho leiteiro; novilhas; vacas em $2^{\circ} ; 3^{\circ}$ e com mais de 3 parição, através da imunofenotipagem pela técnica de citometria de fluxo depois do parto, observaram menores valores de linfócitos B e T no momento do parto e aumento no pós-parto; e maiores concentrações de linfócitos $\mathrm{T} \mathrm{CD}^{+}$no colostro em comparação com o sangue. Os dados sugerem que o perfil celular das vacas no periparto influenciou 0 status imunitário. E conclui que com o número de células diminuiu nas vacas mais velhas.

Estudo realizado por Meglia et al. (2005) demonstrou a influência dos valores de energia da dieta na resposta imune de vacas leiteiras no período de transição, comparando três dietas que forneciam quantidades energéticas distinta tendo como parâmetro as recomendações estabelecidas para a raça, dessa forma os grupos foram alimentados com $75 \%, 110 \%$ e $178 \%$ de energia metabolizável. No pré-parto 
foi encontrado leucograma de estresse; entretanto, não foi observada diferença na atividade de neutrófilos, pela fagocitose e burst oxidativo; a população de linfócitos $B$ aumentou; os linfócitos $T$ e suas subpopulações diminuíram, em vacas com rações de baixa energia. As proporções de linfócitos $\mathrm{T}$ auxiliares $\left(\mathrm{CD}^{+}\right)$e citotóxicos $\left(\mathrm{CD} 8^{+}\right)$, linfócitos $\mathrm{B}$ e a ativação dessas células $\left(\mathrm{CD} 25^{+}\right)$aumentaram no início da lactação, em comparação com os resultados obtidos no período seco. Apesar da relação observada entre nutrição e resposta imune no período de transição, o mecanismo que disparou a diminuição da resposta imune não foi elucidado, dessa forma, os autores indicaram a necessidade da realização de mais estudos.

Ohtsuka et al. (2006a) estabeleceram relação entre a resposta imune celular e condição nutricional no período periparto. Nesse estudo verificaram que vacas submetidas à restrição energética, utilizando como referencia o Nutrient Requirements of Dairy Cattle (NRC), apresentaram hipoglicemia, hipocolesterolemia e menor proporção de células $\mathrm{CD}^{+}$e $\mathrm{CD}^{+}$. A resposta imune celular manteve-se diminuída por 3 meses após a parição nos animais com hipocolesterolemia, enquanto os animais com concentrações séricas adequadas de colesterol apresentaram normalização das proporções das subpopulações linfocitárias próximo à parição. Estes pesquisadores afirmaram que a deficiência nutricional poderia ser responsável pela imunodeficiência observada, com depleção de células $T \mathrm{CD}^{+} \mathrm{e}$ redução na imunidade mediada por células.

Ohtsuka et al., (2006b) avaliaram dois rebanhos leiteiros que apresentavam mastite frequente ( $A$ e $B$ ), e um rebanho com baixa ocorrência de mastite $(C)$. Cinco animais de cada rebanho foram avaliados em cinco diferentes momentos da lactação: período seco - dia 60 antes do parto ao dia do parto; início da lactação do dia do parto aos 50 dias pós-parto; pico da lactação - do dia 51 ao dia 100 pósparto; metade da lactação - Do dia 101 ao dia 200 pós-parto; final da lactação após 201 dias pós-parto. Os rebanhos que apresentavam mastite recorrente (A e B) apresentaram evidente insuficiência de nutrientes digestivos totais (NDT) e proteína bruta (PB) nos programas de alimentação, baixos valores de nitrogênio ureico sanguíneo e colesterol total. Os baixos valores de nitrogênio ureico sanguíneo e colesterol total indicam deficiência de energia protéica, sugerindo que esse achado estava relacionado com a alta frequência do aparecimento de mastite nos rebanhos. Os rebanhos $A$ e $B$ apresentaram menor número de linfócitos $T\left(C D 3^{+}\right)$, especialmente no final da lactação; e as células $\mathrm{CD} 4^{+}$foram menores nos rebanhos 
A e B no meio e fim da lactação. Estes autores concluíram que condições imunes celulares anormais seguidas de condições inadequadas de nutrição foram observadas em vacas que demonstraram alta freqüência de mastite.

Ster, Loiselle; Lacasse (2012) avaliaram o efeito dos dias pós-parto (2; 5 e 61), na função dos linfócitos (in vitro), em vacas ordenhadas uma vez ao dia ou duas vezes ao dia na primeira semana e nas demais semanas todas foram ordenhadas 2 vezes por dia. Estes autores também adicionaram NEFA e BHB, adquiridos comercialmente, ao cultivo dos leucócitos mononucleares. No geral a proliferação dos linfócitos no dia 61 foi maior que aquela obtida no dia 2 e dia 5; e comparando se os grupos a proliferação dos linfócitos foi maior no dia 2 e dia 5 em vacas ordenhadas $1 \mathrm{x}$ ao dia. $\mathrm{A}$ proliferação foi inversamente proporcional à concentração de NEFA e BHB séricos $(r=-86)$. A adição de NEFA comercial no cultivo do dia 61 para atingir concentração equivalente àquela do dia 5 , impactou na proliferação dos linfócitos. Nenhum efeito da adição do BHB foi observada. A liberação de IFN-gama, obtida do sobrenadante do cultivo e dosada por kit de ELISA comercial, foi menor quando o soro proveniente do dia 5 foi adicionado ao cultivo celular, em relação ao dia 61. A adição de NEFA também impactou na produção de IFN-gama. Desta forma, os autores concluíram que a imunidade celular parece ser afetada pelas concentrações de NEFA.

Wathes et al. (2009) encontraram menor quantidade de leucócitos totais e linfócitos em vacas com baixas concentrações séricas de IGF-I. Outros pesquisadores (IRELAND et al., 1995; MALLARD et al., 1997) também associaram as oscilações deste hormônio com as subpopulações de LT (linfócitos).

Ireland et al. (1995) estudaram a relação entre a concentração do hormônio de crescimento e o IGF-I na proporção de linfócitos $\mathrm{T}\left(\mathrm{CD} 2^{+}\right), \mathrm{CD}^{+}, \mathrm{CD} 8^{+}$e $ү \delta$ $\left(\mathrm{WC}^{+}\right)$em 32 vacas Holandesas no período de transição. As vacas foram avaliadas na terceira semana pré-parto (-3); no momento da parição (0); e no pós-parto (semanas $+3 \mathrm{e}+6)$. As concentrações séricas de $\mathrm{GH}$ apresentaram-se elevados no momento da parição e semana +3. O IGF-I apresentou maiores valores nas semanas $-3,+3$ e +6 , quando comparado ao momento da parição. A menor porcentagem dos $\mathrm{LT} \gamma \delta\left(\mathrm{WC}^{+}\right)$e $\mathrm{CD} 8^{+}$coincidiu com os maiores valores de $\mathrm{GH}$ na semana +3 . Com base nestes resultados os autores sugeriram que as flutuações hormonais no periparto são responsáveis pelas alterações nas subpopulações de linfócitos sanguíneos. 
O grupo canadense de Ireland et al. (1995) liderados por Mallard, continuaram seus estudos focados na influência dos hormônios GH, IGF-I e cortisol na resposta imune humoral de vacas do periparto ao pico de lactação. Mallard et al. (1997) imunizaram vacas com duas doses de ovalbumina (OVA) e Escherichia coli J5 (J5) nas semanas - $-8,-3$ em relação a previsão da data do parto; no momento do parto as vacas foram revacinadas para OVA. Nesta pesquisa, os autores observaram aumento nos valores séricos de $\mathrm{GH}$ e cortisol das três semanas que antecederam o parto até a parição e diminuição do IGF-I. Em seguida, o cortisol e GH diminuíram até a semana 03 pós-parto e o IGF-I aumentou; a resposta para a produção de anticorpos (ACs) séricos nas vacas estudadas foi baixa. Além disso, observaram correlação negativa entre as concentrações de IGF-I e anticorpos, desta forma, sugeriram que a ausência do IGF-I poderia ter contribuído para a baixa produção de anticorpos por interferir na função de linfócitos $B$.

Kimura, Reinhardt e Goff (2006) avaliaram os linfócitos T (CD3 ${ }^{+}$) em vacas da semana -2 a +2 em relação ao parto e verificaram redução na concentração do Ca2+ intracelular, que atua como segundo mensageiro na transdução do sinal imunológico. Observaram também que os estoques de cálcio intracelular de células mononucleares periféricas diminuiu significativamente no parto, retornando aos valores normais conforme o cálcio sanguíneo. Portanto, sugeriram que o aumento da demanda do cálcio em vacas no periparto pode afetar negativamente os estoques de cálcio intracelular das células imunes, contribuindo para imunossupressão observada nesses animais no período de transição. 


\section{MATERIAL E MÉTODOS}

\subsection{ETAPA DE TRIAGEM}

Foram triadas 13 fêmeas bovinas, gestantes, multíparas ( $2^{-}$a $4^{\text {a }}$ lactação), da raça Holandesa preta e branca, com parto previsto para 25 de outubro de 2013 (Figura 2). Os animais eram provenientes da Agência Paulista de Tecnologia dos Agronegócios (APTA) - Gado de Leite, localizada na cidade de Nova Odessa, interior de São Paulo (latitude 22॰75’S e longitude 47॰27’W).

Os critérios para a seleção da propriedade foram: fácil acesso entre a fazenda e a FMVZ-USP; e concentração de fêmeas gestantes com previsão de parto para a época de estudo pretendida.

Figura 2 - Vacas triadas para avaliação do perfil metabólico e resposta imune celular no período de transição - São Paulo - 2013

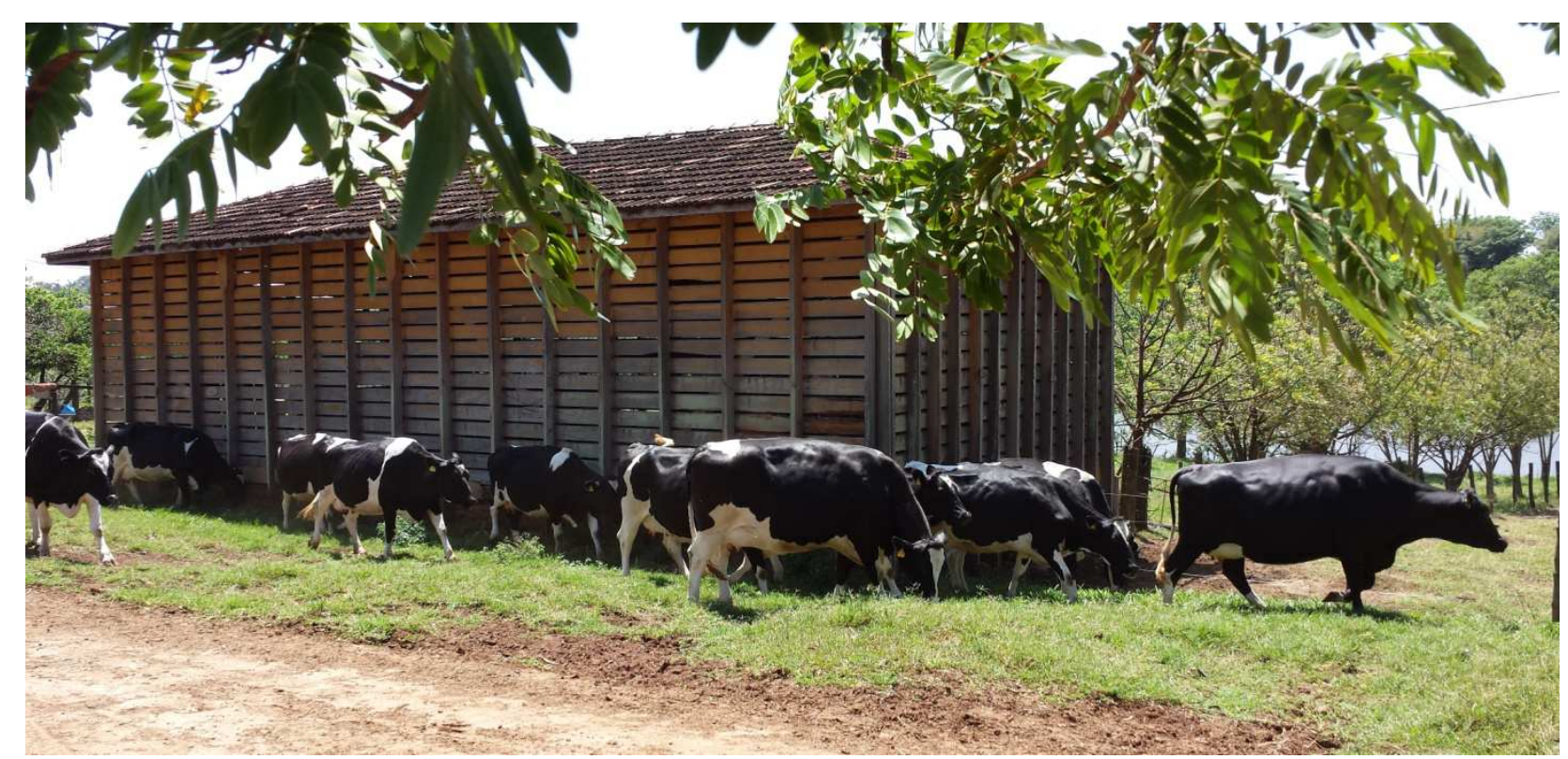

Fonte: (BALDACIM, 2013) 


\subsection{MANEJO NUTRICIONAL}

As vacas eram mantidas em regime em pasto e a dietas que foram oferecidas às fêmeas durante o período pré-parto e pós-parto estão descritas no quadro 1. As vacas eram transferidas para o lote pré-parto em aproximadamente 45 dias antes da data prevista da parição. Após o parto, as vacas eram separadas por lotes segundo sua produção leiteira.

Quadro 1 - Dieta fornecida para vacas Holandesas no pré e pós-parto - São Paulo 2013

\begin{tabular}{|cc|}
\hline \multicolumn{2}{|c|}{ Dieta pré-parto } \\
\hline Componentes & Peso (kg/animal/dia) \\
Feno & 0,3 \\
Silagem de milho (MS $=43 \%)$ & 3,0 \\
Ração concentrada & \\
\hline Dieta pós-parto & Peso (kg/animal/dia) \\
\hline Componentes & 35,0 \\
Silagem de milho (MS $=43 \%)$ & $1,0^{*}$ \\
Ração concentrada &
\end{tabular}

Fonte: (BALDACIM, 2013)

Legenda: *Para cada 3 litros (L) de leite produzido; MS = matéria seca

A ração fornecida às vacas leiteiras era formulada e produzida na fábrica de ração do APTA, e suplementada com minerais e vitaminas (núcleo) (Quadro 2). O sal mineral e a água eram fornecidos no cocho ad libitum.

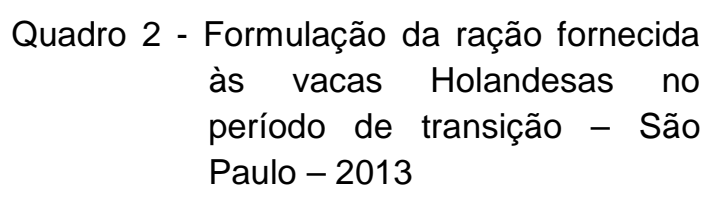

\begin{tabular}{|l|c|}
\hline \multicolumn{1}{|c|}{ Ingredientes } & Ração (\%) \\
\hline Milho grão Moído & 69 \\
Farelo de Soja & 27 \\
Núcleo mineral/vitamínico & 3 \\
Sal Proteinado & 1 \\
Total & 100 \\
\hline
\end{tabular}

Fonte: (BALDACIM, 2013) 
No cocho os animais recebiam silagem de milho, ração concentrada e feno no pré-parto, conforme o estágio produtivo. A composição bromatológica da dieta total oferecida no pré e pós-parto encontra-se no quadro 3.

$$
\begin{gathered}
\text { Quadro } 3 \text { - Composição bromatológica da } \\
\text { dieta total oferecida para vacas } \\
\text { Holandesas no pré e pós-parto - } \\
\text { São Paulo - } 2013
\end{gathered}
$$

\begin{tabular}{|lcrrr|}
\hline & \multicolumn{4}{c|}{ Lote } \\
\cline { 2 - 5 } & Unidade & Pré-parto & \multicolumn{1}{c|}{ M1 } & M2/M3 \\
\hline MST & kg MS/Dia & 11,44 & 34,45 & 40,35 \\
PB & $\%$ & 11,6 & 16,7 & 17,9 \\
FB & $\%$ & 18,8 & 12,7 & 11,4 \\
EE & $\%$ & 1,8 & 1,8 & 1,8 \\
MM & $\%$ & 3,5 & 3,9 & 4,1 \\
ENN & $\%$ & 64,3 & 64,9 & 64,8 \\
Ca & $g$ & 24,4 & 84,5 & 101,0 \\
P & $\mathrm{g}$ & 27,3 & 116,0 & 143,6 \\
\hline
\end{tabular}

Fonte: (BALDACIM, 2013)

Legenda: MST: Matéria seca total; P.B: Proteína bruta; ENN: Extrato não nitrogenado; FB: Fibra bruta; MM: Matéria mineral; ENN: Extrato não nitrogenado; Ca: Cálcio; P: fósforo.

\subsection{PERÍODOS DE AVALIAÇÃO}

Foram realizadas avaliações durante semanais a partir da $2^{\mathrm{a}}$ semana préparto à $3^{a}$ semana pós-parto (Quadro 4). 
Quadro 4 - Momentos das avaliações realizadas nas vacas Holandesas no período de transição - São Paulo - 2013

\begin{tabular}{|cc|}
\hline \multicolumn{2}{|c|}{ Momentos } \\
\hline M-2 & 2 semanas pré-parto \\
M-1 & 1 semana pré-parto \\
M0 & $0-12 \mathrm{~h}$ pós-parto \\
M1 & 1 semana pós-parto \\
M2 & 2 semanas pós-parto \\
M3 & 3 semanas pós-parto \\
\hline
\end{tabular}

Fonte: (BALDACIM, 2013)

Legenda: $M-2: 2^{\circ}$ semana pré-parto; $M-1: 1^{\circ}$ semana pré-parto; M0: dia do parto; $\mathrm{M} 1 ; 1^{\circ}$ semana pós-parto; M2: $2^{\circ}$ semana pós-parto; M3: $3^{\circ}$ semana pós-parto.

\subsection{ETAPA A CAMPO}

No período de transição foi realizada a avaliação do escore de condição corporal, obtenção das amostras de sangue.

\subsection{1- Avaliação do Escore Corporal}

O ECC foi determinado utilizando uma escala de 1 a 5 com intervalo de 0,5 , segundo os critérios estabelecidos por Edmonson et al. (1989) (Figura 3). 
Figura 3 - Escores de condição corporal (ECC) encontrados durante a avaliação de vacas Holandesas no período de transição - São Paulo - 2013

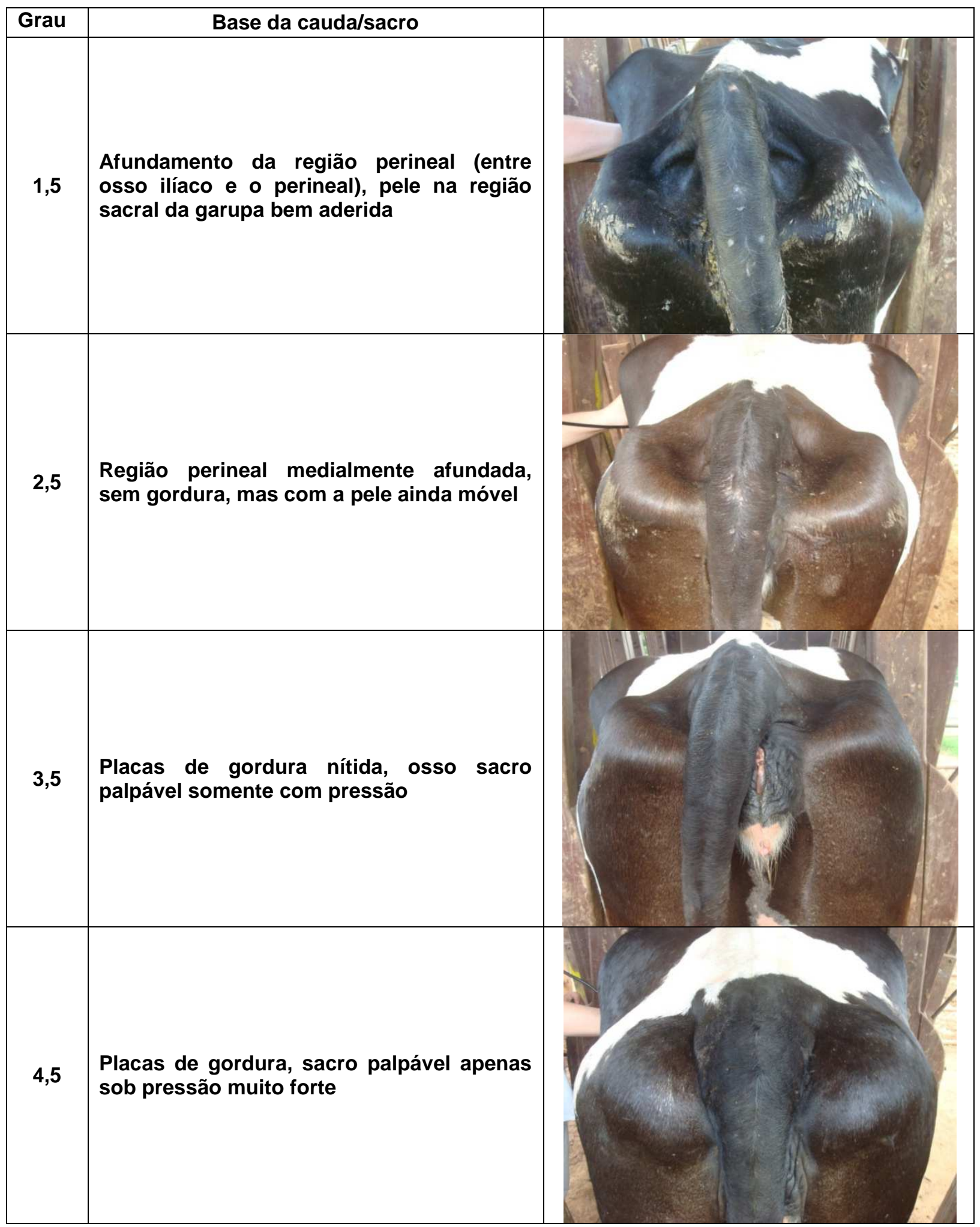

Fonte: Figura (BALDACIM, 2013). Texto Adaptado de Rosenberger et al. (2008) 


\subsubsection{Obtenção das amostras}

Amostras de sangue foram colhidas por punção da veia coccígea por meio de sistema a vácuo em tubos contendo ácido etileno diaminotetracético (EDTA), fluoreto de sódio e sem anticoagulante, a fim de obter-se, sangue total, plasma e soro, respectivamente. $O$ sangue total foi utilizado para a realização do leucograma e imunofenotipagem das células mononucleares; o plasma para dosagem de glicose; e o soro para determinação do NEFA, BHB, cálcio, colesterol, triglicerídeos, albumina, proteína total, gamaglutamiltransferase (GGT), Aspartato transaminase (AST) e IGF-1.

As amostras de sangue foram acondicionadas em caixa herméticas e transportadas sob refrigeração $\left(4^{\circ} \mathrm{C}\right)$ até o laboratório da Faculdade de Medicina Veterinária e Zootecnia (FMVZ) da Universidade de São Paulo (USP), onde foram processadas e armazenadas até a realização das provas pretendidas.

\subsubsection{Produção leiteira}

O controle da produção leiteira individual das vacas foi realizado pelos funcionários da ordenha, no qual os dados foram anotados diariamente em fichas.

\subsection{ETAPA LABORATORIAL}

As amostras foram analisadas nos laboratórios de pesquisa da FMVZ/USP. O tempo entre a colheita e início do processamento foi inferior a quatro horas. 


\subsubsection{Processamento e armazenamento das amostras}

No laboratório, os tubos contendo sangue sem anticoagulante e com fluoreto de sódio foram centrifugados ${ }^{1}$ à $1.223 \mathrm{G}$ por 10 minutos à $4^{\circ} \mathrm{C}$ para obtenção do soro e plasma, respectivamente, transferidos e acondicionado em microtubos ( $1 \mathrm{~mL}$ ) ${ }^{2}$. Por fim, as alíquotas foram armazenadas em freezer $-80^{\circ} \mathrm{C}$ até o momento da realização das análises.

\subsubsection{Determinação dos Parâmetros Bioquímicos}

Alíquotas de soro e de plasma foram descongeladas em geladeira (overnight), homogeneizadas em vortex para posterior realização dos testes bioquímicos em analisador bioquímico automático ${ }^{3}$. Foram utilizados kits comerciais (Quadro 5), empregando-se a metodologia descrita pelo fabricante. Para a mensuração da concentração de glicose foram utilizados amostra de plasma e para os demais provas, amostras de soro.

Quadro 5 - Especificações dos kits comerciais utilizados nas análises bioquímicas - São Paulo - 2013

\begin{tabular}{|lcc|}
\hline Parâmetros & Número Catálogo & Marca \\
\hline Glicose & GL 3815 & \\
NEFA & FA 115 & \\
BHB & FA 1007 & \\
Triglicerídeos & TR 3823 & Randox® \\
Colesterol & CH 3810 & \\
Proteína total & TP 4001 & \\
Albumina & AB 3800 & \\
AST & AS 3804 & \\
GGT & GT 3817 \\
Cálcio total & CA 3871 & \\
\hline
\end{tabular}

Fonte: (BALDACIM, 2013)

Legenda: NEFA: Ácidos graxos não esterificados; BHB: Betahidroxibutirato; AST - Aspartato aminotransferase; GGT - Gama glutamiltransferase.

\footnotetext{
${ }^{1}$ Eppendorf ${ }^{\circledR}$ Centrifuge 5810R

2 Eppendorf ${ }^{\circledR}$

${ }^{3}$ RX Daytona (Randox®)
} 
O teor de globulina foi determinado pela diferença entre a proteína sérica total e albumina. A relação albumina:globulina foi calculada para obtenção de um indicador de lesão hepática $(<0.5)$.

A mensuração das concentrações séricas de IGF-I foi realizada por equipamento de testes de imunoensaios pelo método da quimiluminescência ${ }^{4}$.

As concentrações de cálcio ionizado $\left(\mathrm{Ca}^{++}\right)$circulante foram estimadas utilizando-se a fórmula apresentada por Barreto Junior (2007).

$$
\begin{aligned}
& C a++(\mathrm{mmol} / \mathrm{L})=\frac{6 \mathrm{Ca}(\text { total })-(P T / 3)}{P T+6} \\
& \text { PT = proteína total }
\end{aligned}
$$

\subsubsection{Interpretação do perfil metabólico}

Para determinação das frequências de distúrbios metabólicos durante o período de transição, foram selecionados pontos de corte de acordo com intervalos de referências disponíveis na literatura (Quadro 6).

\footnotetext{
${ }^{4}$ Immulite 1000 (Siemens®)
} 
Quadro 6 - Intervalos de referência dos parâmetros bioquímicos adotados para determinação das freqüências dos distúrbios metabólicos em vacas leiteiras no período de transição São Paulo - 2013

\begin{tabular}{|llcc|}
\hline \multicolumn{4}{c}{ Valores de Referência das Análises Bioquímicas } \\
\cline { 2 - 4 } & Unidades & $\begin{array}{c}\text { Valores de } \\
\text { Referência }\end{array}$ & Autores \\
\hline Glicose & $\mathrm{mg} / \mathrm{L}$ & $450-750$ & Kaneko, 2008 \\
NEFA & $\mathrm{mmol} / \mathrm{L}$ & $<0,4$ & LeBlanc, 2010 \\
BHB & $\mathrm{mmol} / \mathrm{L}$ & $<1.400$ & Gordon, 2013 \\
Colesterol Total & $\mathrm{mg} / \mathrm{L}$ & $800-1200$ & Kaneko, 2008 \\
Triglicerídeos & $\mathrm{mg} / \mathrm{L}$ & $0-140$ & Kaneko, 2008 \\
IGF-I & $\mathrm{mg} / \mathrm{L}$ & $0,035-0,109$ & Nowak, et al. 2014 \\
Proteína Total & $\mathrm{mg} / \mathrm{L}$ & $68000-86000$ & Smith, 2006 \\
Albumina & $\mathrm{mg} / \mathrm{L}$ & $30300-35500$ & Kaneko, 2008 \\
Globulina & $\mathrm{mg} / \mathrm{L}$ & $30000-34800$ & Kaneko, 2008 \\
AST & $\mathrm{U} / \mathrm{L}$ & $78-132$ & Kaneko, 2008 \\
GGT & $\mathrm{U} / \mathrm{L}$ & $6.1-17.4$ & Kaneko, 2008 \\
Cálcio Total & $\mathrm{mg} / \mathrm{L}$ & $>85,0$ & Goff, 2004 \\
\hline
\end{tabular}

\subsubsection{Leucograma}

O número total de leucócitos sanguíneos foi obtido por meio da contagem automática $^{5}$, e a contagem diferencial pela avaliação dos esfregaços sanguíneos e diferenciação do padrão leucocitário ao microscópio óptico com aumento de $1000 \mathrm{X}$ (BIRGEL; BENESI, 1982).

\subsubsection{Imunofenotipagem dos linfócitos}

Abaixo serão descritos as etapas realizadas na imunofenotipagem dos linfócitos.

${ }^{5} \mathrm{ABC}$ Vet $-\mathrm{ABX}{ }^{\circledR}$ 


\subsubsection{Lise e marcação dos linfócitos}

As subpopulações dos linfócitos sanguíneos foram determinadas utilizando-se anticorpos monoclonais específicos para receptores de superfície celular pela técnica de citometria de fluxo, conforme painel de anticorpos apresentado no quadro 7.

Inicialmente, foram transferidos $100 \mu \mathrm{L}$ de sangue total para tubos de citometria de fluxo sobre gelo triturado. A lise dos eritrócitos foi realizada pela adição de $2 \mathrm{~mL}$ de solução de cloreto de sódio $(\mathrm{NaCl})$ a $0,2 \%$ (20 segundos) e $2 \mathrm{~mL}$ solução de $\mathrm{NaCl}$ a 1,6\% para restituição da osmolaridade sanguínea.Em seguida, a mistura foi centrifugada ${ }^{6}$ por 8 minutos à $600 \times \mathrm{xg}$ a $4^{\circ} \mathrm{C}$, brake $6 / 6$. O sobrenadante foi desprezado e o pellet celular reservado para repetição da lise isotônica das hemácias. Por fim, o pellet de leucócitos foi reservado para a marcação com os anticorpos monoclonais.

As concentrações de anticorpos monoclonais primários e secundários utilizadas para a marcação das células foram determinadas pela titulação de anticorpos, realizada antes do início do experimento quadro 8. Para tanto, foi adicionado $100 \mu \mathrm{L}$ da solução de anticorpos monoclonais primários aos leucócitos, em seguida, os tubos foram mantidos sobre refrigeração por 30 minutos. Após lavagem das células, foi adicionado $100 \mu \mathrm{L}$ da solução contendo os anticorpos secundários FITC (Fluorescente Isothiocyanate) e PECY5 (Phycoerythrin and Cyanine), mantidos sob refrigeração durante 40 minutos protegidos da luz. As células foram lavadas novamente, e ressuspensas em $300 \mu \mathrm{L}$ de PBS. Por fim, foram adquiridos 20 mil eventos em citômetro de fluxo ${ }^{7}$, utilizando-se o programa CellQuest Pro $^{\circledR 8}$.

As análises dos eventos adquiridos no citômetro de fluxo foram feitas utilizando-se o software Flowjo, versão 7.2.5 (Tree Star) (Figuras 4 e 5).

\footnotetext{
${ }^{6}$ Eppendorf ${ }^{\circledast}$ Centrifuge 5810R

${ }^{7}$ FACSCalibur $^{\mathrm{TM}}$ - BD Biosciences

${ }^{8}$ Becton Dickinson Immunocytometry System
} 
Quadro 7 - Painel de anticorpos primários e secundários utilizados na marcação de células sanguíneas mononucleares de vacas Holandesas no período de transição - São Paulo 2013

\begin{tabular}{|ccccc|}
\hline Anticorpos & ACs Primários & Clones & $\begin{array}{c}\text { Concentração } \\
\text { do Produto }\end{array}$ & Marca \\
\hline CD3 & Mouse anti-bovine IgG1 & MM1A & $1 \mathrm{mg} / \mathrm{mL}$ & \\
CD4 & Mouse anti-bovine M & CACT 83B & $1 \mathrm{mg} / \mathrm{mL}$ & Washington State University \\
CD8 & Mouse anti-bovine IGM & BAQ111A & $1 \mathrm{mg} / \mathrm{mL}$ & \\
CD21 & Mouse anti-bovine IgM & BAQ15A & $1 \mathrm{mg} / \mathrm{mL}$ & \\
FITC & Goat anti-mouse IgM & M31501 & $1 \mu \mathrm{g} / \mathrm{mL}$ & Life Technologies \\
Pe-Cy5.5 & Goat anti-mouse IgG1 & M32018 & $1 \mu \mathrm{g} / \mathrm{mL}$ & \\
\hline
\end{tabular}

Fonte: (BALDACIM, 2013)

Quadro 8 - Concentrações de anticorpos monoclonais primários e secundários adotadas para marcação dos leucócitos mononucleares de vacas Holandesas no período de transição - São Paulo 2013

\begin{tabular}{|c|c|c|c|c|c|c|}
\hline Anticorpos Primários & $\begin{array}{l}\text { Ac 10 } \\
(\mu L)^{*}\end{array}$ & $\begin{array}{l}\text { PBS } \\
(\mu L)\end{array}$ & Conc & Anticorpos Secundários & $\begin{array}{c}\text { Ac 2o } \\
(\mu L)\end{array}$ & $\begin{array}{l}\text { PBS } \\
(\mu L)\end{array}$ \\
\hline Mouse anti-bovine CD3 & 0.50 & 99.50 & $0,50 \%$ & Goat anti-mouse PeCY 5 & 0.25 & 99.75 \\
\hline Mouse anti-bovine CD21 & 0.50 & 99.50 & $0,50 \%$ & Goat anti-mouse FITC & 0.50 & 99.5 \\
\hline Mouse anti-bovine CD4 & 0.25 & 99.75 & $0,25 \%$ & Goat anti-mouse FITC & 0.25 & 99.75 \\
\hline Mouse anti-bovine CD8 & 0.50 & 99.50 & $0,50 \%$ & Goat anti-mouse FITC & 1,00 & 99,00 \\
\hline
\end{tabular}

Fonte: (BALDACIM, 2013)

Legenda: *1 $\mu \mathrm{L}$ equivale a $1 \mu \mathrm{g}$ 
Figura 4 - Distribuição dos leucócitos sanguíneos de vacas Holandesas no período de transição: seleção dos leucócitos totais de acordo com seu tamanho (FSC) e granulosidade (SSC) (A); Seleção dos linfócitos pelo SSC (0-200) e FSC (400600) (B); histograma da subpopulação de linfócitos B (FL1-CD21 $\left.{ }^{+}\right)$(C); e linfócitos T (FL3-CD3 $\left.{ }^{+}\right)(D)$ - São Paulo - 2013

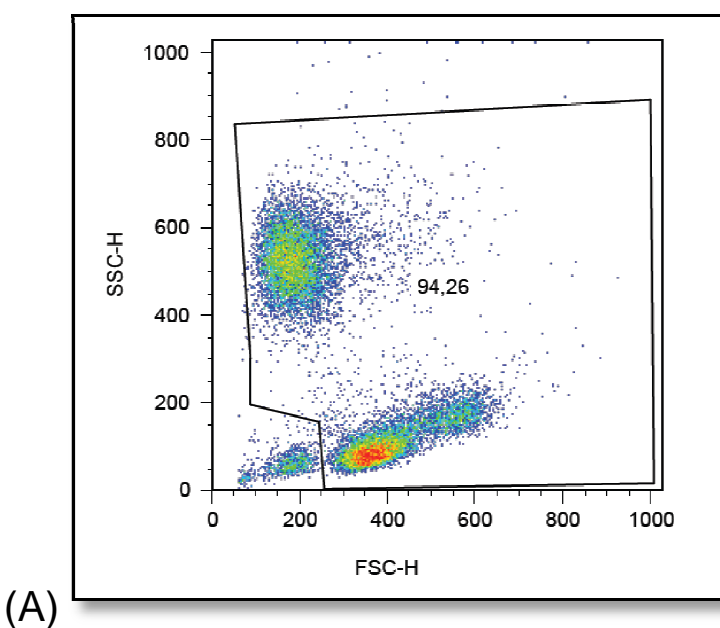

(A)

(B)

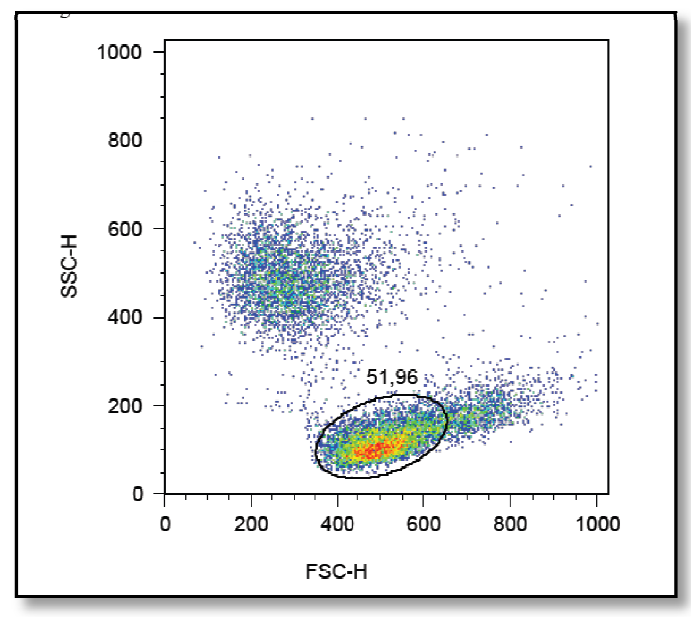

(C)

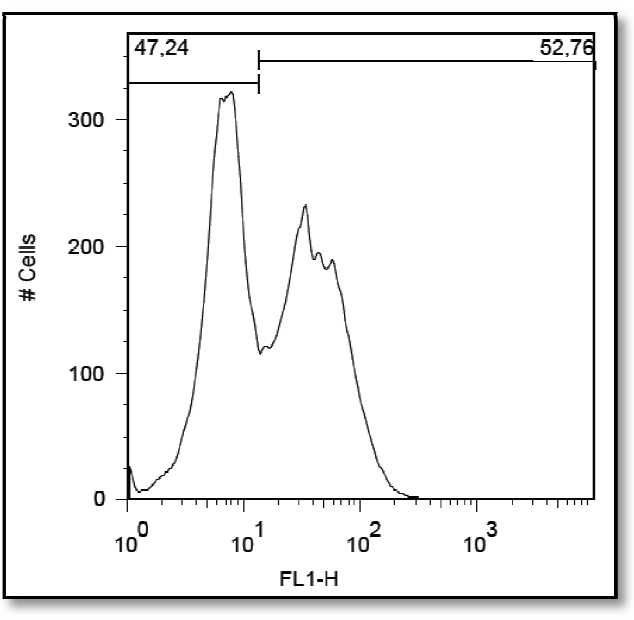

(D)

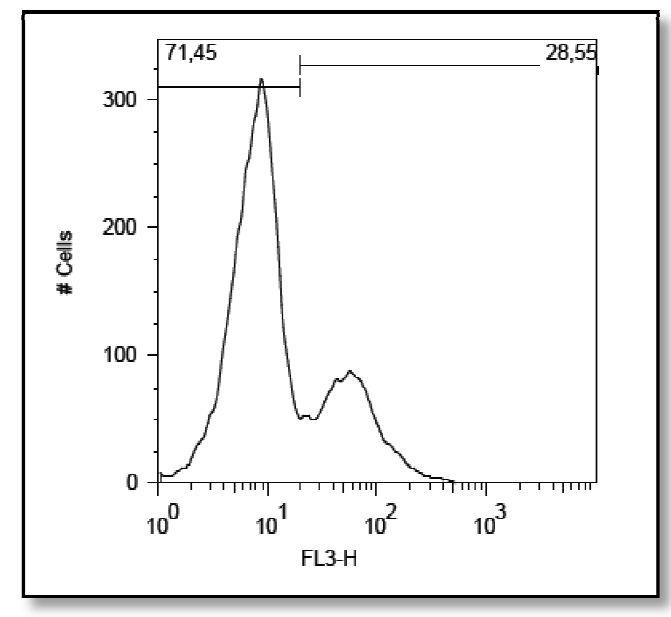

Fonte: (BALDACIM, 2013) 
Figura 5 - Subpopulações de linfócitos T CD3+CD4+ (A) e CD3+CD8+ (B) no sangue de vacas Holandesas no período de transição - São Paulo - 2013
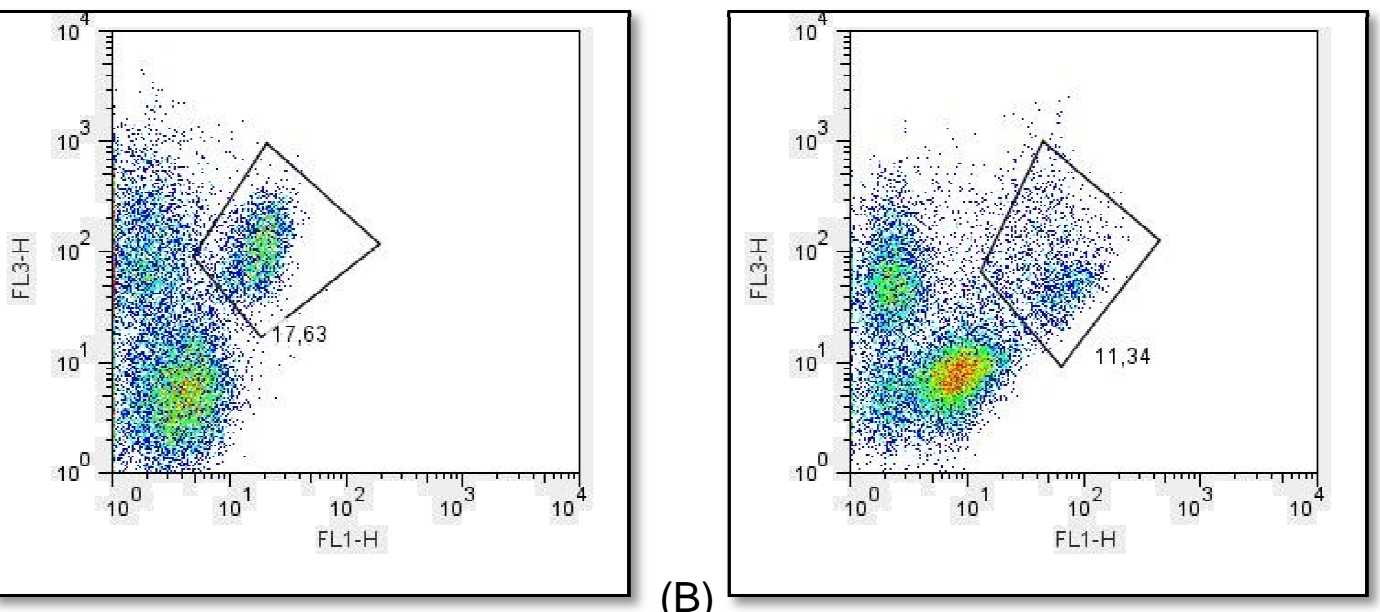

Fonte: (BALDACIM, 2013) 


\subsection{ANÁLISES ESTATÍSTICAS}

A análise estatística e gráficos apresentados foram realizados utilizando-se 0 programa estatístico SPSS $17.0^{9}$.

Primeiramente, todas as variáveis em todos os momentos foram testadas quanto à aderência a distribuição normal pelo teste de Kolmogorov-Smirnov. Com este teste, constatou-se que houve variáveis com distribuição normal e outras não, então optou-se por testes não paramétricos para todas as variáveis. Além disso, o baixo número de animais em cada grupo favoreceu o poder estatístico dos testes não paramétricos.

Foram calculadas as frequências dos dados qualitativos e dependentes, aplicando-se o teste de Cochran, para detectar as diferenças em relação aos momentos $(P \leq 0.05)$. A este último teste, quando apresentou pelo menos um momento significantemente diferente, foram realizadas comparações múltiplas pelo teste post-hoc McNemar com correção de Bonferroni para comparações múltiplas utilizando $\alpha=0,05$.

As amostras dependentes com valores quantitativos foram analisadas pelo Teste de Friedman, para avaliar a diferença entre os tempos. A este último teste, quando apresentou, pelo menos um tempo significativamente diferente, foram realizadas as comparações múltiplas por meio do teste de Wilcoxon com correção de Bonferroni para comparações múltiplas utilizando $\alpha=0,05$.

Foi calculada a média aritmética da produção leiteira diária das vacas do M1 ao M3.

Todos os testes foram considerados significativos quando $p<0,05$.

\footnotetext{
${ }^{9}$ SPSS Statistics for Windows, Version 17.0. Armonk, NY: IBM Corp
} 


\section{RESULTADOS}

Esta pesquisa avaliou a relação entre o perfil metabólico e a imunidade celular de vacas leiteiras da raça Holandesa no período de transição, por meio de testes bioquímicos, leucograma e a imunofenotipagem dos leucócitos mononucleares do sangue periférico. Optou-se por incluir ainda o histórico de doenças da produção, para melhorar a qualidade da interpretação dos resultados e discussão apresentada.

Neste tópico será apresentada a estatística descritiva dos parâmetros avaliados, destacando-se as diferenças obtidas entre os momentos deste estudo.

As significâncias entre os momentos de estudo que apresentaram ou não diferenças estatísticas pelos testes post hoc podem ser visualizadas na sessão apêndice A desta dissertação.

\subsection{DOENÇAS DA PRODUÇÃO NO PERÍODO DE TRANSIÇÃO}

Durante o período de estudo foi relatada a ocorrência de doenças da produção nas vacas Holandesas, selecionadas para o desenvolvimento desta pesquisa. No período pré-parto ( $M-2$ ao $M-1)$ não foram relatadas enfermidades, e os animais não foram submetidos a protocolos terapêuticos.

Os distúrbios iniciaram-se a partir da parição (M0), observando-se episódios de distocias em 4/13 vacas deste estudo, sendo que uma delas predispôs a um quadro de cetose. No pós-parto imediato, observaram-se distúrbios do sistema reprodutivo (Quadro 9). 
Tabela 1 - Ocorrência de doenças da produção em vacas Holandesas no período de transição - São Paulo - 2013

\begin{tabular}{|c|c|c|c|c|c|c|c|c|}
\hline \multirow{2}{*}{ Id. } & \multicolumn{8}{|c|}{ Momentos } \\
\hline & MO & ECC & M1 & ECC & M2 & ECC & M3 & ECC \\
\hline 1332 & Distocia & 4,5 & & 3,5 & & 4 & & 4 \\
\hline 1333 & Distocia & & & 3,5 & $\begin{array}{c}\text { Infecção } \\
\text { uterina }\end{array}$ & 4 & & 4,5 \\
\hline 1356 & & 3 & & 2,5 & & 3 & & 3 \\
\hline 1384 & & 3,5 & & 3,5 & & 4 & $\begin{array}{l}\text { Infecção } \\
\text { uterina }\end{array}$ & 4 \\
\hline 1429 & Distocia & 2,5 & Cetose & 2 & Cetose & 1,5 & & 2 \\
\hline 1433 & Distocia & 3,5 & & 3 & $\begin{array}{l}\text { Infecção } \\
\text { uterina }\end{array}$ & 4 & & 4 \\
\hline 1437 & & 3 & & 3 & & 3 & & 3,5 \\
\hline 1445 & $\begin{array}{l}\text { Retenção de } \\
\text { Placenta }\end{array}$ & 3,5 & $\begin{array}{l}\text { Infecção } \\
\text { uterina }\end{array}$ & 2,5 & $\begin{array}{l}\text { Infecção } \\
\text { uterina }\end{array}$ & 3 & $\begin{array}{c}\text { Infecção } \\
\text { uterina }\end{array}$ & 3,5 \\
\hline 1447 & & 3 & & 2,5 & & 2,5 & & 2,5 \\
\hline 1453 & Diarréia & 3,5 & & 3,5 & $\begin{array}{c}\text { Infecção } \\
\text { uterina }\end{array}$ & 3,5 & & 4 \\
\hline 1478 & & 2,5 & & 2,5 & & 2,5 & & 2,5 \\
\hline 4409 & Hipocalcemia & 4 & & 4 & & 4 & & 4 \\
\hline 4410 & & 3,5 & Laceração & 3,5 & Laceração & 3,5 & Laceração & 3,5 \\
\hline $\begin{array}{l}\text { Fonte } \\
\text { Lege }\end{array}$ & $\begin{array}{l}\text { (BALDACIM, } \\
\text { רda: Vaca } 1478 \\
1429 \text { - Ge } \\
\text { teto; Id: I } \\
\text { semana p }\end{array}$ & $\begin{array}{l}\text { 013) } \\
\text { - Par } \\
\text { stação } \\
\text { lentific } \\
\text { ss-part }\end{array}$ & $\begin{array}{l}\text { oilomatose; } \\
\text { gemelar e p } \\
\text { ação; M0: d } \\
\text { o; M3: } 3^{\circ} \text { ser }\end{array}$ & $\begin{array}{l}\text { Vaca } \\
\text { utrefo } \\
\text { a do }\end{array}$ & $\begin{array}{l}3 \text { - "Síndr } \\
\text { fetal; Vac } \\
\text { to; M1; } 1^{\circ} \\
\text { parto. }\end{array}$ & $\begin{array}{l}\text { e da } \\
410-1 \\
\text { mana }\end{array}$ & $\begin{array}{l}\text { laca caída' } \\
\text { aceração n } \\
\text { pós-parto; }\end{array}$ & $\begin{array}{l}\text { Vaca } \\
\text { Ima e } \\
\text { 2: } 2^{\circ}\end{array}$ \\
\hline
\end{tabular}

\subsection{PRODUÇÃO LEITEIRA}

A estatística descritiva referente à produção leiteira das vacas no momentos M1 a M3 está apresentada na tabela 1 e figura 6 . Foi possível observar aumento da produção de leite semanal do M1 ao M3. 
Tabela 2 - Média aritmética, mediana, desvio padrão e amplitude de variação da produção de leite diária de vacas Holandesas, da primeira a terceira semana pós-parto - São Paulo 2013

\begin{tabular}{cccc}
\hline \multicolumn{4}{c}{ Produção de Leite (L/dia) } \\
\hline & M1 & M2 & M3 \\
Média & 24,2 & 27,8 & 29,6 \\
Mediana & 23,0 & 30,3 & 30,5 \\
Desvio padrão & 4,7 & 7,5 & 7,0 \\
Mínimo & 17,7 & 8,3 & 13,7 \\
Máximo & 33,0 & 37,7 & 40,1 \\
\hline
\end{tabular}

Fonte: (BALDACIM, 2013)

Legenda: $\mathrm{M} 1 ; 1^{\circ}$ semana pós-parto; $\mathrm{M} 2: 2^{\circ}$ semana pós-parto; M3: $3^{\circ}$ semana pós-parto.

Figura 6 - Média aritmética de variação da produção de leite diária de vacas Holandesas, da primeira a terceira semana pós-parto - São Paulo - 2013

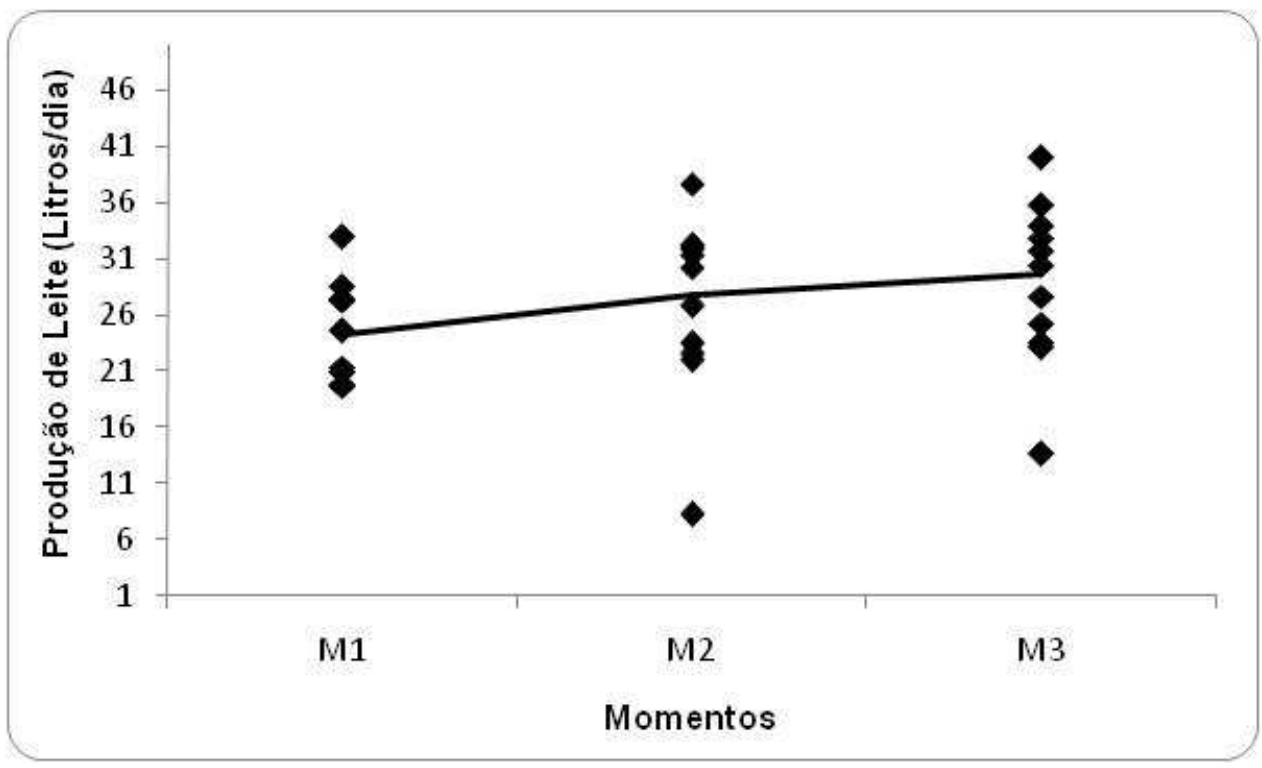

Fonte: (BALDACIM, 2013)

Legenda: $M 1 ; 1^{\circ}$ semana pós-parto; $M 2: 2^{\circ}$ semana pós-parto; M3: $3^{\circ}$ semana pós-parto. 


\subsection{ESCORE DE CONDIÇÃO CORPORAL}

O escore de Condição Corporal (ECC) apresentou variações durante o período de transição $(P=0,000)$. Foi observado ECC decrescente da semana $M-2$ pré-parto ao M1, observando melhorias no ECC nos momentos subsequentes (M2 e M3) (Tabela 2 e Figura 7). Diferença estatística foi detectada entre os momentos M-1 e $\mathrm{M} 1(\mathrm{P}=0,003)$ para o ECC.

Tabela 3 - Escore de condição corporal (ECC) (escala de 1 a 5) em vacas Holandesas no Período de transição - São Paulo - 2013

\begin{tabular}{cccccccc}
\hline \multicolumn{7}{c}{ Escore de Condição Corporal (ECC) } \\
\hline Momentos & M-2 & M-1 & M0 & M1 & M2 & M3 & $\begin{array}{c}\text { Valor } \\
\text { de P }\end{array}$ \\
\hline Média & 3,9 & 3,8 & 3,3 & 3,0 & 3,3 & 3,5 & \\
Mediana & 4,0 & 3,8 & 3,5 & 3,0 & 3,5 & 3,5 & \\
Desvio & 0,4 & 0,5 & 0,6 & 0,6 & 0,8 & 0,7 & $0,000^{*}$ \\
Padrão & 3,5 & 3,0 & 2,5 & 2,0 & 1,5 & 2,0 & \\
Mínimo & 4,5 & 4,5 & 4,5 & 4,0 & 4,0 & 4,5 & \\
Maximo & 4,5
\end{tabular}

Fonte: (BALDACIM, 2013)

Legenda: ${ }^{*} \mathrm{P}<0,05 ; \mathrm{M}-2$ : $2^{\circ}$ semana pré-parto; $\mathrm{M}-1$ : $1^{\circ}$ semana pré-parto; $\mathrm{M0}$ : dia do parto; $M 1 ; 1^{\circ}$ semana pós-parto; M2: $2^{\circ}$ semana pós-parto; M3: $3^{\circ}$ semana pós-parto. 
Figura 7 - Escore de Condição Corporal (ECC) (escala de 1 a 5) em vacas Holandesas no período de transição - São Paulo - 2013

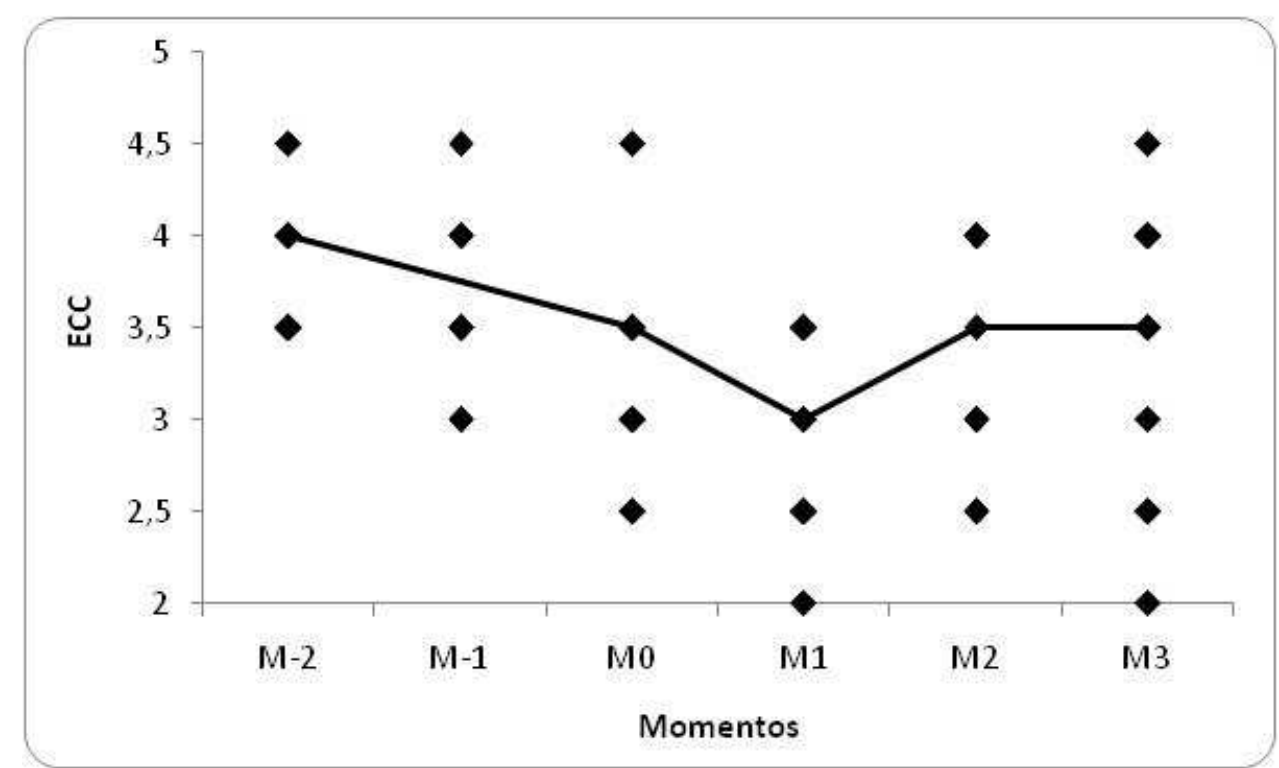

Fonte: (BALDACIM, 2013)

Legenda: $M-2: 2^{\circ}$ semana pré-parto; $M-1: 1^{\circ}$ semana pré-parto; M0: dia do parto; $M 1 ; 1^{\circ}$ semana pós-parto; M2: $2^{\circ}$ semana pós-parto; M3: $3^{\circ}$ semana pós-parto.

\subsection{METABOLISMO ENERGÉTICO}

Os dados das variáveis que avaliaram o perfil do metabolismo energético (glicose, NEFA, BHB, triglicerídeos, colesterol e IGF-I) serão apresentados nos tópicos seguintes.

\subsubsection{Marcadores}

O metabolismo energético das vacas Holandesas no período de transição foi estabelecido pela mensuração das concentrações plasmáticas de glicose e concentrações séricas de colesterol, triglicerídeos, ácidos graxos não esterificados (NEFA) e $\beta$-hidroxibutirato (BHB). Os dados obtidos estão ilustrados na tabela 3 e figura 8.

Foram detectadas variações em todas as variáveis do metabolismo energético das vacas Holandesas durante o período de transição pelo teste de Friedman $(\mathrm{P}<0,05)($ Tabela 3$)$. 
Os teores medianos de glicose aumentaram gradativamente do pré-parto ao parto, observando-se diferenças entre os valores do M0 e M2 ( $P=0,003)$;

As concentrações de NEFA aumentaram de forma gradual dos momentos pré-parto aos momentos pós-parto, sendo possível observar diferenças entre os valores do momento $M-2$ versus $M 0, M 1, M 2$ e M3 $(P<0,003)$; $M-1$ e $M 1(P=0,003)$; M0 e M2-M3 $(P<0,003)$; e M1 e M3 $(P<0,003)$.

Os teores de BHB em nenhum momento ficou acima dos valores de referencia, porem apresentaram aumento gradativo do pré-parto, ao M1 (pico máximo), observando decréscimo dos valores nos momentos subsequentes. No entanto, não foi possível detectar diferenças entre os momentos ( $P>0,003)$.

As concentrações de triglicérides apresentaram pico máximo no $\mathrm{M}-1$ observando-se diminuição dos valores nos momentos subsequentes, detectando-se diferenças entre $\mathrm{M}-1$ versus $\mathrm{M} 0, \mathrm{M} 1, \mathrm{M} 2$ e M3.

Os teores de colesterol diminuíram do pré-parto, atingindo menor valor no M0 e M1, observado-se aumento nos momentos subseqüentes. Foi possível detectar diferenças entre $\mathrm{M}-1$ e M0; e M3 versus M-1, M0, M1 e M2.

As concentrações séricas de IGF-I diminuíram gradativamente do pré-parto (M-2) ao parto (M0), apresentando estabilidade temporária até M2 e aumento ligeiro em M3, ficando a baixo dos valores de referencia em todos os momentos, exceto em M-2. Foi possível detectar diferenças entre M-2 e M1; M-1 e demais tempos pósparto $(P<0,03)$. 
Tabela 4 - Valores médios e medianos dos marcadores do perfil metabólico de vacas Holandesas no período de transição - São Paulo - 2013

\begin{tabular}{|c|c|c|c|c|c|c|c|c|}
\hline \multicolumn{9}{|c|}{ Momentos } \\
\hline Marcadores & & $M-2$ & $M-1$ & MO & M1 & M2 & M3 & Valor de $p$ \\
\hline \multirow{5}{*}{$\begin{array}{c}\text { Glicose } \\
(\mathrm{mg} / \mathrm{L})\end{array}$} & Média & 705,64 & 728,42 & 845,42 & 688,17 & 653,58 & 657,17 & \multirow{5}{*}{$0.001^{*}$} \\
\hline & Mediana & 678,00 & 721,50 & 850,50 & 691,00 & 646,00 & 664,50 & \\
\hline & $\begin{array}{l}\text { Desvio } \\
\text { Padrão }\end{array}$ & 6,21 & 59,81 & 171,42 & 41,45 & 62,63 & 42,76 & \\
\hline & Mínimo & 626,00 & 637,00 & 631,00 & 624,00 & 566,00 & 579,00 & \\
\hline & Maximo & 806,00 & 853,00 & 1282,00 & 748,00 & 767,00 & 734,00 & \\
\hline \multirow{5}{*}{$\begin{array}{c}\text { NEFA } \\
(\mathrm{mmol} / \mathrm{L})\end{array}$} & Média & 0,12 & 0,29 & 0,87 & 0,82 & 0,49 & 0,35 & \multirow{5}{*}{$0.001^{*}$} \\
\hline & Mediana & 0,13 & 0,17 & 0,74 & 0,72 & 0,41 & 0,34 & \\
\hline & $\begin{array}{l}\text { Desvio } \\
\text { Padrão }\end{array}$ & 0,08 & 0,32 & 0,33 & 0,38 & 0,28 & 0,16 & \\
\hline & Mínimo & 0,01 & 0,07 & 0,44 & 0,43 & 0,13 & 0,14 & \\
\hline & Maximo & 0,32 & 1,24 & 1,52 & 1,78 & 1,05 & 0,68 & \\
\hline \multirow{5}{*}{$\mathrm{BHB}(\mathrm{mmol} / \mathrm{L})$} & Média & 0,52 & 0,56 & 0,66 & 0,84 & 0,61 & 0,51 & \multirow{5}{*}{$0.011^{*}$} \\
\hline & Mediana & 0,54 & 0,55 & 0,66 & 0,76 & 0,59 & 0,43 & \\
\hline & $\begin{array}{l}\text { Desvio } \\
\text { Padrão }\end{array}$ & 0,13 & 0,11 & 0,16 & 0,41 & 0,26 & 0,31 & \\
\hline & Mínimo & 0,32 & 0,42 & 0,44 & 0,38 & 0,23 & 0,28 & \\
\hline & Maximo & 0,74 & 0,75 & 1,02 & 1,74 & 1,03 & 1,45 & \\
\hline \multirow{5}{*}{$\begin{array}{l}\text { Triglicerideos } \\
\text { (mg/L) }\end{array}$} & Média & 164,08 & 235,67 & 98,50 & 95,58 & 84,85 & 95,46 & \multirow{5}{*}{$0.000^{*}$} \\
\hline & Mediana & 154,00 & 205,00 & 100,50 & 98,00 & 86,00 & 99,00 & \\
\hline & $\begin{array}{l}\text { Desvio } \\
\text { Padrão }\end{array}$ & 68,51 & 73,09 & 26,36 & 25,22 & 21,21 & 19,58 & \\
\hline & Mínimo & 67,00 & 136,00 & 53,00 & 49,00 & 50,00 & 66,00 & \\
\hline & Maximo & 262,00 & 363,00 & 139,00 & 138,00 & 112,00 & 145,00 & \\
\hline \multirow{5}{*}{$\begin{array}{l}\text { Colesterol } \\
(\mathrm{mg} / \mathrm{L})\end{array}$} & Média & 770,33 & 834,33 & 739,50 & 758,67 & 850,38 & 1000,15 & \multirow{5}{*}{$0.000^{*}$} \\
\hline & Mediana & 818,50 & 829,00 & 752,50 & 755,00 & 809,00 & 984,00 & \\
\hline & $\begin{array}{l}\text { Desvio } \\
\text { Padrão }\end{array}$ & 139,36 & 98,26 & 85,93 & 136,14 & 226,04 & 144,27 & \\
\hline & Mínimo & 509,00 & 690,00 & 602,00 & 477,00 & 466,00 & 792,00 & \\
\hline & Maximo & 936,00 & 1072,00 & 913,00 & 965,00 & 1274,00 & 1299,00 & \\
\hline \multirow{5}{*}{ IGF-I (mg/L) } & Média & 10,71 & 10,23 & 4,17 & 3,23 & 3,87 & 4,86 & \multirow{5}{*}{$0.000^{*}$} \\
\hline & Mediana & 11,20 & 8,67 & 2,52 & 2,50 & 2,50 & 4,50 & \\
\hline & $\begin{array}{l}\text { Desvio } \\
\text { Padrão }\end{array}$ & 5,08 & 5,40 & 2,77 & 1,53 & 1,92 & 2,70 & \\
\hline & Mínimo & 3,89 & 2,50 & 2,50 & 2,50 & 2,50 & 2,50 & \\
\hline & Maximo & 19,70 & 19,30 & 10,40 & 7,58 & 8,11 & 10,70 & \\
\hline
\end{tabular}

Fonte: (BALDACIM, 2013)

Legenda: *Diferença significativa no teste de Friedman $(p \leq 0,05)$; NEFA - Ácidos Graxos Não Esterificados; BHB - Beta-hidroxibutirato; IGF-I - Fator de Crescimento Semelhante à Insulina. M-2: $2^{\circ}$ semana pré-parto; M-1: $1^{\circ}$ semana pré-parto; M0: dia do parto; M1; $1^{\circ}$ semana pós-parto; M2: $2^{\circ}$ semana pós-parto; M3: $3^{\circ}$ semana pós-parto. 
Figura 8 - Marcadores do perfil energético de vacas Holandesas período de transição: glicose (A), NEFA (B), BHB (C), Triglicerídeos (D), Colesterol (E) e IGF-I (F) - São Paulo 2013

(A)

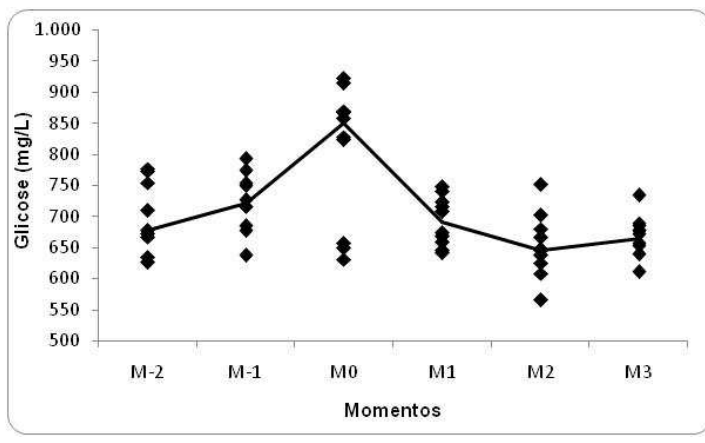

(C)
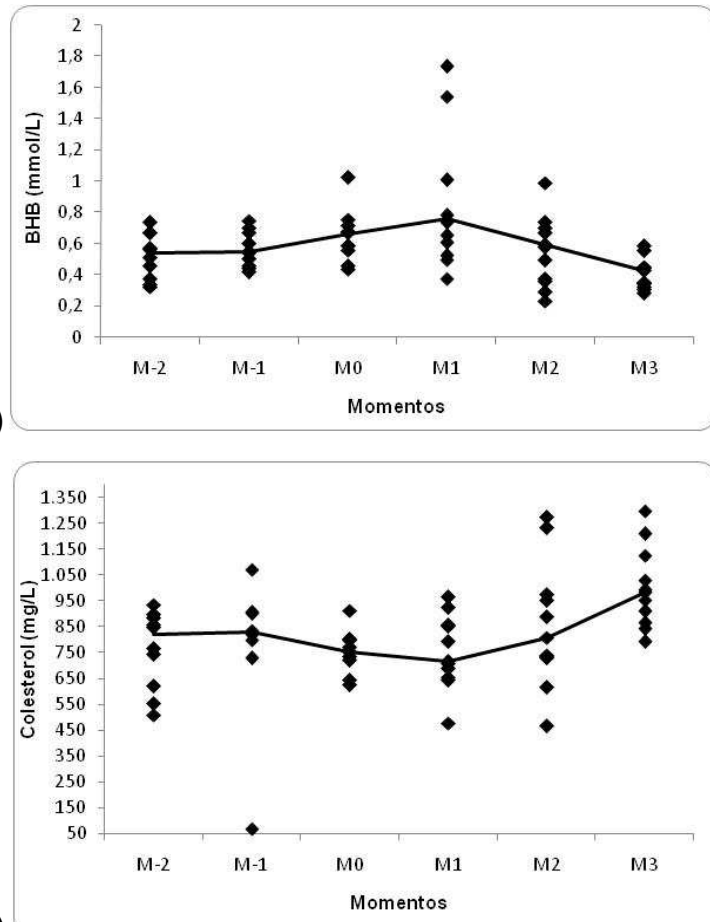

(E)

Fonte: (BALDACIM, 2013)

Legenda: NEFA - Ácidos Graxos Não Esterificados; BHB - Beta-hidroxibutirato; IGF-I - Fator de Crescimento Semelhante à Insulina; $M-2: 2^{\circ}$ semana pré-parto; $M-1: 1^{\circ}$ semana pré-parto; M0: dia do parto; $\mathrm{M} 1 ; 1^{\circ}$ semana pós-parto; M2: $2^{\circ}$ semana pós-parto; M3: $3^{\circ}$ semana pós-parto.
(B)

(D)

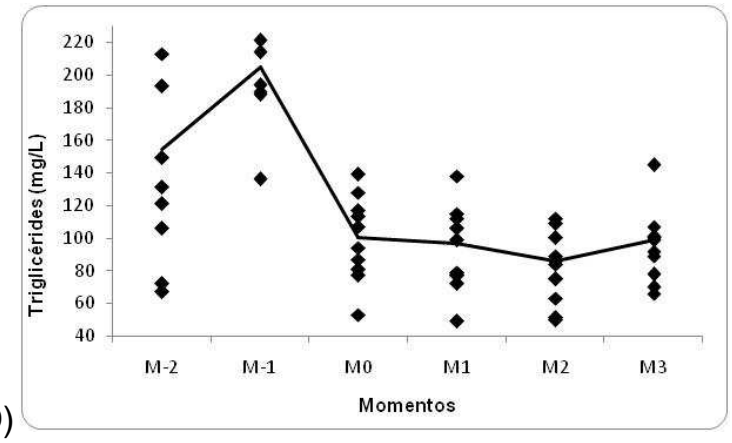

(F)

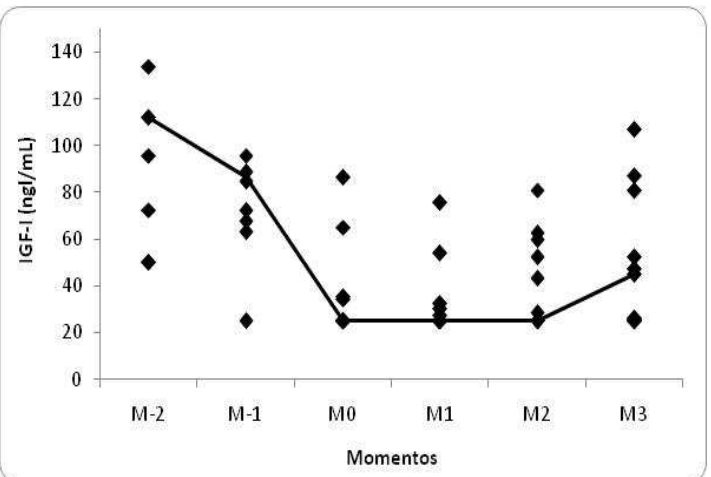

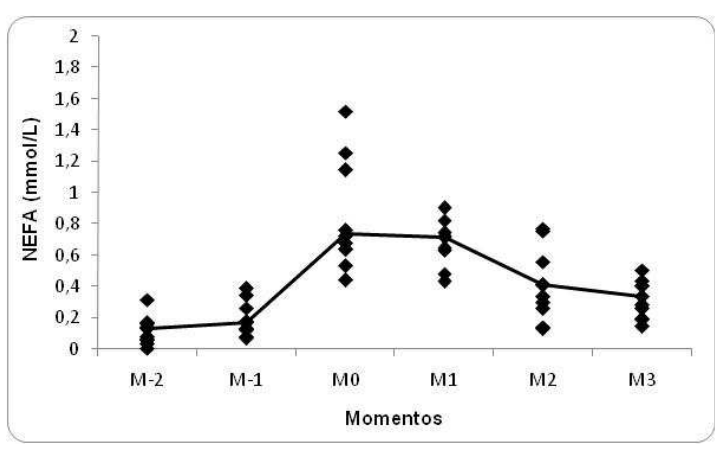




\subsubsection{Ocorrência de cetose}

Os valores absolutos e frequências de animais apresentando NEFA e BHB acima dos pontos de corte estabelecidos na literatura estão dispostos na tabela $4 \mathrm{e}$ figura 9.

Foi possível identificar $100 \%$ das vacas apresentando elevados teores de NEFA entre M-1 e M0, porém apenas $3 / 13(23,1 \%)$ dos animais apresentaram concentrações de BHB acima dos valores de referência (> $1.400 \mathrm{mmol} / \mathrm{L}$ ) em M1 e M3, porém apenas um animal apresentou as manifestações clínicas decorrente deste quadro.

O caso de cetose clínica relatado nesta pesquisa ocorreu no animal 1429, o qual apresentou parto gemelar distócico. $O$ parto distócico do primeiro bezerro ocorreu no dia 19/10 no período noturno, ocorrendo evidenciação do segundo filhote no dia 20/10. O animal foi encaminhado ao Hospital de Bovinos e Pequenos Ruminantes da Faculdade de Medicina e Veterinária da Universidade de São Paulo onde foram realizadas manobras obstétricas e retirada do feto que se encontrava enfizematoso.

Após o procedimento para retirada do feto, foi realizada lavagem uterina com solução fisiológica diária no animal e tratamento com antibiótico sistêmico por cerca de 10 dias. Além disso, após a constatação de que não houve expulsão da placenta, foi realizada aplicação uma de prostaglandina $F 2 \alpha$, e massagem retal diária e drenagem do conteúdo contido no útero. No quarto dia após o início desse processo, o animal expulsou completamente a placenta.

Após 09 dias de permanência do animal no hospital veterinário foi realizado teste com a urina do mesmo constatando uma densidade de 1,015, pH 6.0 e corpos cetônicos (++). Foi realizado tratamento do animal com glicose $5 \%$, Solução Ringer com Lactato, e Solução Fisiológica 0,9\%. Após 1 hora deste procedimento, foi realizado o teste urinário não sendo constatada a presença de corpos cetônicos.

No dia seguinte, no período da manhã, foram realizados dois testes distintos, um repetindo o procedimento anterior, utilizando-se a fita para avaliação da urina, onde não foi detectada a presença de corpos cetônicos, e um segundo exame utilizando-se sangue total para determinação do valor de corpos cetônicos, sendo detectada a quantidade de $1.8 \mathrm{mmol} / \mathrm{L}$. Após a detecção, foi realizado tratamento 
com propilenogicol. No período da tarde o mesmo tratamento foi repetido, assim como o exame realizado a partir da urina, não sendo detectada a presença de corpos cetônicos na mesma. Houve melhora do quadro do animal, e alta do mesmo. Foi recomendada continuidade do tratamento com propilenogicol e antibiótico na propriedade.

Tabela 5 - Número (N.) e frequências (\%) de vacas Holandesas no período de transição que apresentaram concentrações séricas de NEFA e BHB acima dos intervalos de referências - São Paulo - 2013

\begin{tabular}{|c|c|c|c|}
\hline \multirow[b]{2}{*}{ Momentos } & \multirow[b]{2}{*}{ Variáveis } & \multicolumn{2}{|c|}{ Marcadores Energéticos } \\
\hline & & $\begin{array}{c}\text { NEFA } \\
(>0.4 \mathrm{mmol} / \mathrm{L})\end{array}$ & $\begin{array}{c}\text { BHB } \\
(>1.200 \mathrm{mmol} / \mathrm{L})\end{array}$ \\
\hline \multirow{2}{*}{$M-2(n=11)$} & N. & 0,0 & 0,0 \\
\hline & $\%$ & 0,0 & 0,0 \\
\hline \multirow{2}{*}{$M-1(n=12)$} & N. & 2,0 & 0,0 \\
\hline & $\%$ & 16,7 & 0,0 \\
\hline \multirow{2}{*}{$\mathrm{M} 0(\mathrm{n}=12)$} & N. & 12,0 & 0,0 \\
\hline & $\%$ & 100,0 & 0,0 \\
\hline \multirow{2}{*}{ M1 $(n=12)$} & N. & 12,0 & 2,0 \\
\hline & $\%$ & 100,0 & 16,7 \\
\hline \multirow{2}{*}{$M 2(n=13)$} & N. & 8,0 & 0,0 \\
\hline & $\%$ & 61,5 & 0,0 \\
\hline \multirow{2}{*}{ M3 $(n=13)$} & $\mathrm{N}$. & 6,0 & 1,0 \\
\hline & $\%$ & 46,2 & 7,7 \\
\hline
\end{tabular}

Fonte: Tabela (BALDACIM, 2013); Valores de referência (LEBLANC, 2010)

Legenda: NEFA - Ácidos Graxos Não Esterificados; BHB - Betahidroxibutirato; V.R. - Valore de referência; M-2: $2^{\circ}$ semana préparto; $\mathrm{M}-1$ : $1^{\circ}$ semana pré-parto; $\mathrm{M} 0$ : dia do parto; $\mathrm{M} 1 ; 1^{\circ}$ semana pós-parto; M2: $2^{\circ}$ semana pós-parto; M3: $3^{\circ}$ semana pós-parto. 
Figura 9 - Frequências (\%) das vacas Holandesas que apresentaram valores de NEFA acima dos intervalos de referência - São Paulo - 2013

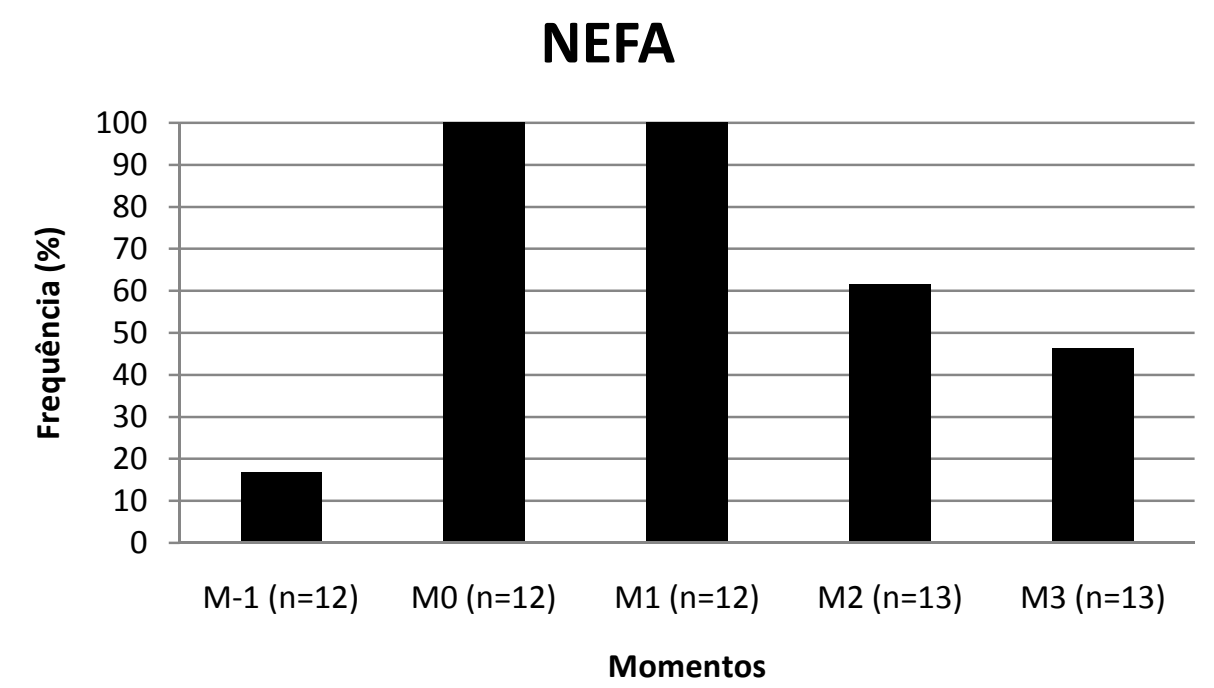

Fonte: (BALDACIM, 2013)

Legenda: NEFA - Ácidos Graxos Não Esterificados; M-2: $2^{\circ}$ semana préparto; $\mathrm{M}-1$ : $1^{\circ}$ semana pré-parto; $\mathrm{M} 0$ : dia do parto; $\mathrm{M} 1 ; 1^{\circ}$ semana pós-parto; M2: $2^{\circ}$ semana pós-parto; M3: $3^{\circ}$ semana pós-parto.

\subsection{METABOLISMO PROTEICO}

Os valores séricos de proteína total (PT), albumina (ALB), globulina (GLOB) e relação albumina:globulina estão dispostos na tabela 5 e figura 10.

Foram observadas variações entre os marcadores do metabolismo proteico do M-2 ao M3: PT $(P=0,000)$, ALB $(P=0,000)$, GLOB $(P=0,000)$ e Relação Albumina:Globulina $(P=0.000)$.

As variações da proteína sérica total e globulinas foram semelhantes, observando pico máximo no M3. Foram detectadas diferenças entre $\mathrm{M} 3$ e demais momentos avaliados, com exceção em M-2 e M2 ( $P=0,002)$.

Os valores de albumina diminuíram no pós-parto (M1 a M3), porém não foi possível detectar diferenças entre os momentos pelo teste post hoc.

A relação albumina:globulina apresentou variações no período de estudo $(P=$ 0,000 ), porém nenhuma das vacas deste estudo apresentou valores inferiores a 0,5. 
Foi possível observar diminuição na relação ALB:GLOB a partir da parição, detectando-se diferenças entre M1 versus M-1 e M3; e M0 versus M2 e M3.

Tabela 6 - Concentrações séricas de proteína total, albumina, globulina e relação albumina:globulina obtidos semanalmente a partir do soro de vacas Holandesas no período de transição - São Paulo - 2013

\begin{tabular}{|c|c|c|c|c|c|c|c|c|}
\hline \multicolumn{9}{|c|}{ Valores encontrados durante o periparto } \\
\hline & & $\mathrm{M}-2$ & $\mathrm{M}-1$ & MO & M1 & M2 & M3 & Valor de $p$ \\
\hline \multirow{5}{*}{$\begin{array}{l}\text { Proteína } \\
\text { Total (mg/L) }\end{array}$} & Média & 65844.2 & 64635.0 & 63359.2 & 63738.5 & 67898.5 & 73473.1 & \multirow{5}{*}{$0.000^{*}$} \\
\hline & Mediana & 64040.0 & 65335.0 & 61940.0 & 64120.0 & 66080.0 & 72830.0 & \\
\hline & $\begin{array}{l}\text { Desvio } \\
\text { Padrão }\end{array}$ & 6549.6 & 5702.0 & 5645.9 & 4408.2 & 6711.5 & 6793.9 & \\
\hline & Mínimo & 57660.0 & 57520.0 & 56390.0 & 56880.0 & 54090.0 & 61360.0 & \\
\hline & Maximo & 78610.0 & 74350.0 & 72190.0 & 72350.0 & 79570.0 & 83850.0 & \\
\hline \multirow{5}{*}{$\begin{array}{l}\text { Albumina } \\
\text { (mg/L) }\end{array}$} & Média & 35500.0 & 35750.0 & 35384.6 & 32153.8 & 31538.5 & 32583.3 & \multirow{5}{*}{$0.000^{*}$} \\
\hline & Mediana & 36000.0 & 35500.0 & 36000.0 & 33000.0 & 32000.0 & 33500.0 & \\
\hline & $\begin{array}{l}\text { Desvio } \\
\text { Padrão }\end{array}$ & 2354.9 & 1288.1 & 2292.7 & 3312.8 & 3928.9 & 3528.0 & \\
\hline & Mínimo & 31000.0 & 33000.0 & 32000.0 & 27000.0 & 26000.0 & 28000.0 & \\
\hline & Maximo & 38000.0 & 37000.0 & 39000.0 & 37000.0 & 39000.0 & 38000.0 & \\
\hline \multirow{5}{*}{$\begin{array}{l}\text { Globulina } \\
\text { (mg/L) }\end{array}$} & Média & 30344.2 & 28885.0 & 27692.5 & 31584.6 & 36360.0 & 41234.2 & \multirow{5}{*}{$0.000^{*}$} \\
\hline & Mediana & 29835.0 & 29335.0 & 26440.0 & 31240.0 & 35440.0 & 41380.0 & \\
\hline & $\begin{array}{l}\text { Desvio } \\
\text { Padrão }\end{array}$ & 5586.0 & 5300.6 & 4707.8 & 3782.6 & 4373.1 & 5295.4 & \\
\hline & Minimo & 23210.0 & 21810.0 & 21040.0 & 26480.0 & 28090.0 & 33360.0 & \\
\hline & Maximo & 40610.0 & 39350.0 & 36190.0 & 38350.0 & 46570.0 & 49850.0 & \\
\hline \multirow{5}{*}{$\begin{array}{l}\text { Relação } \\
\text { ALB:GLOB }\end{array}$} & Média & 1.20 & 1.27 & 1.31 & 1.02 & .87 & .80 & \multirow{5}{*}{$0.000^{*}$} \\
\hline & Mediana & 1.10 & 1.20 & 1.30 & 1.00 & .90 & .80 & \\
\hline & $\begin{array}{l}\text { Desvio } \\
\text { Padrão }\end{array}$ & .23 & .22 & .23 & .18 & .12 & .13 & \\
\hline & Mínimo & .90 & .90 & 1.00 & .80 & .70 & .60 & \\
\hline & Maximo & 1.60 & 1.70 & 1.80 & 1.30 & 1.10 & 1.10 & \\
\hline
\end{tabular}

Fonte: (BALDACIM, 2013)

Legenda: *Diferença significativa no teste de Friedman ( $p \leq 0,05)$; ALB: Albumina; GLOB: Globulina; M2: $2^{\circ}$ semana pré-parto; $M-1: 1^{\circ}$ semana pré-parto; M0: dia do parto; $M 1 ; 1^{\circ}$ semana pósparto; M2: $2^{\circ}$ semana pós-parto; M3: $3^{\circ}$ semana pós-parto. 
Figura 10 - Marcadores do metabolismo protéico no soro de vacas Holandesas no período de transição: (A) Proteína Total, (B) Albumina, (C) Globulina e (D) Relação Albumina/Globulina- São Paulo - 2013

(A)

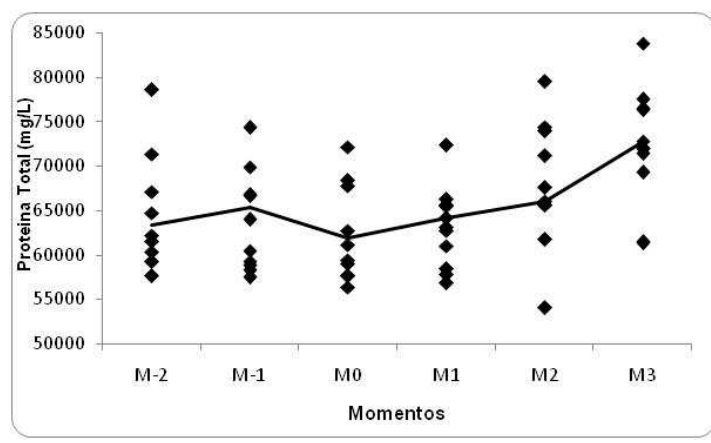

(B)
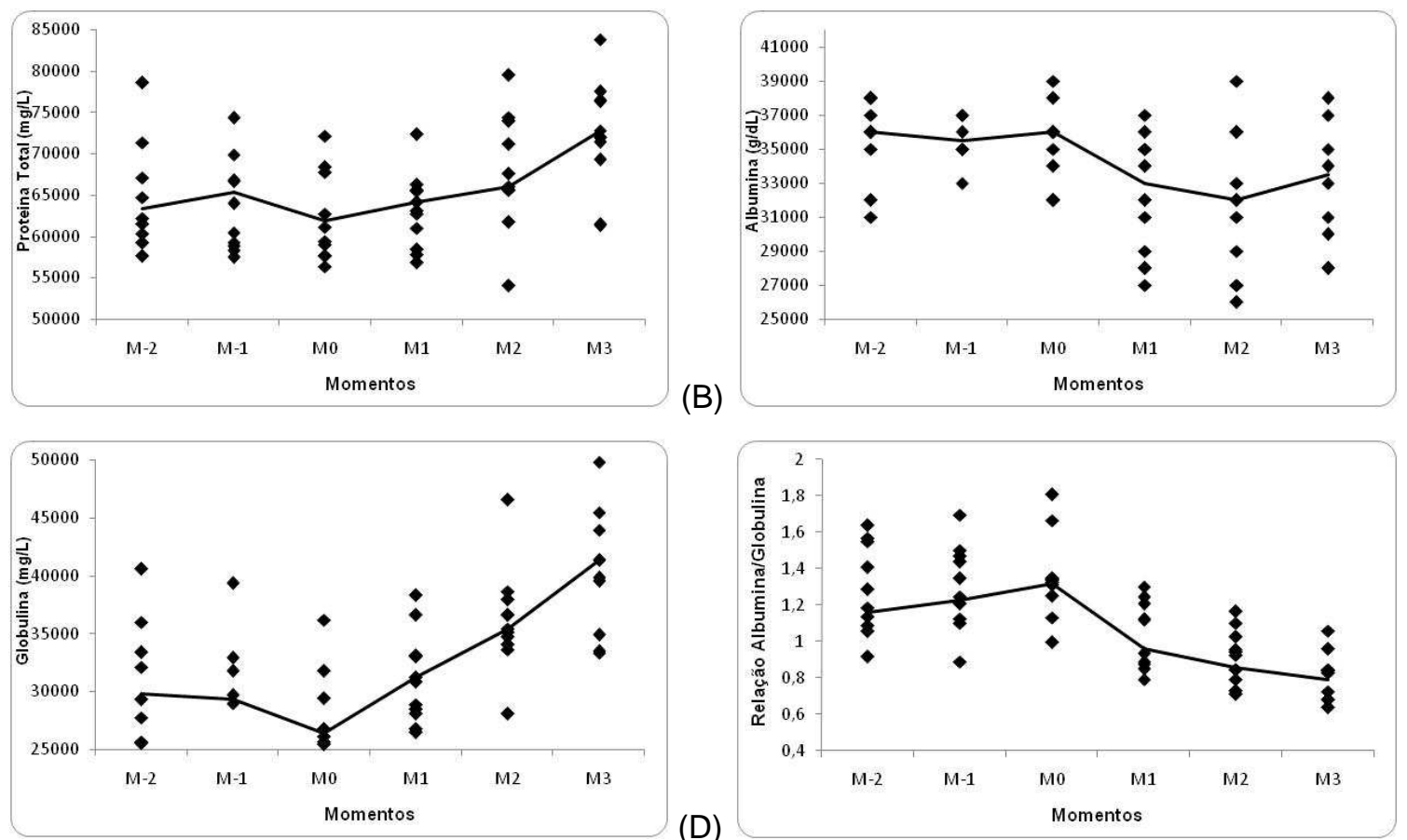

(D)

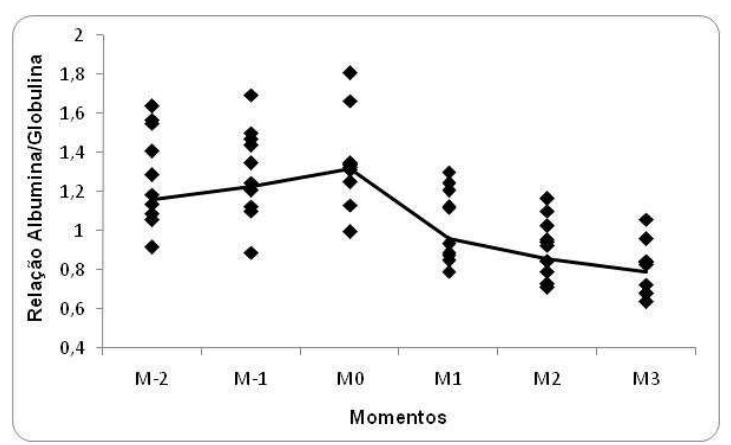

Fonte: (BALDACIM, 2013)

Legenda: $M-2: 2^{\circ}$ semana pré-parto; $M-1$ : $1^{\circ}$ semana pré-parto; $M 0$ : dia do parto; $M 1 ; 1^{\circ}$ semana pós-parto; M2: $2^{\circ}$ semana pós-parto; M3: $3^{\circ}$ semana pós-parto. 


\subsection{ENZIMAS HEPÁTICAS}

A atividade enzimática da AST e GGT está disposta na tabela 6 e figura 11. Foi possível detectar variações nos valores da AST $(P=0,000)$ (Tabela 6). A atividade enzimática da AST aumentou do M-2 ao M1, observando-se redução dos valores nos momentos subsequentes (M2 e M3). Foi possível detectar diferenças entre $M-1$ e M0 ( $P=0,002)$; $M-2$ e M0 ( $P=0,003)$; e M-2 e M1 ( $P=0,003)$.

Não foi possível avaliar diferença significativa para atividade GGT entre os momentos estudados $(P=0,096)$.

Tabela 7 - Atividade das enzimas hepáticas AST e GGT no soro de vacas Holandesas no período de transição - São Paulo - 2013

\begin{tabular}{|c|c|c|c|c|c|c|c|c|}
\hline & & \multicolumn{7}{|c|}{ Enzimas hepaticas ao longo tempo } \\
\hline & & M-2 & M-1 & M0 & M1 & M2 & M3 & Valor de $p$ \\
\hline \multirow{5}{*}{ AST (U/L) } & Média & 43.97 & 52.38 & 74.71 & 69.71 & 56.92 & 58.82 & \multirow{5}{*}{$0.000^{*}$} \\
\hline & Mediana & 48.43 & 53.64 & 62.06 & 69.32 & 58.77 & 58.64 & \\
\hline & $\begin{array}{l}\text { Desvio } \\
\text { Padrão }\end{array}$ & 12.41 & 5.99 & 45.71 & 14.75 & 13.33 & 9.49 & \\
\hline & Mínimo & 18.77 & 42.61 & 49.05 & 50.01 & 30.28 & 43.70 & \\
\hline & Maximo & 59.05 & 62.75 & 222.35 & 95.76 & 84.12 & 75.62 & \\
\hline \multirow{5}{*}{ GGT (U/L) } & Média & 8.20 & 9.41 & 8.65 & 9.48 & 8.09 & 9.98 & \multirow{5}{*}{0.096} \\
\hline & Mediana & 8.05 & 10.62 & 8.18 & 10.55 & 6.62 & 12.30 & \\
\hline & $\begin{array}{l}\text { Desvio } \\
\text { Padrão }\end{array}$ & 4.37 & 4.76 & 5.10 & 3.72 & 4.80 & 6.09 & \\
\hline & Mínimo & 2.97 & 1.35 & 1.49 & 2.16 & 3.38 & 1.35 & \\
\hline & Maximo & 17.44 & 18.39 & 18.12 & 13.66 & 18.66 & 18.93 & \\
\hline
\end{tabular}

Fonte: (BALDACIM, 2013)

Legenda: * Valores com diferenças significativas. Posteriormente foi aplicado o Teste de Wilcoxon; AST - Aspartato aminotransferase; GGT - Gama glutamiltransferase; $\mathrm{M}-2$ : $2^{\circ}$ semana pré-parto; $\mathrm{M}-1$ : $1^{\circ}$ semana pré-parto; $\mathrm{M0}$ : dia do parto; $M 1 ; 1^{\circ}$ semana pós-parto; M2: $2^{\circ}$ semana pós-parto; M3: $3^{\circ}$ semana pós-parto. 
Figura 11 - Enzimas hepáticas no soro de vacas Holandesas no Período de Transição: AST (A) e GGT (B) - São Paulo - 2013
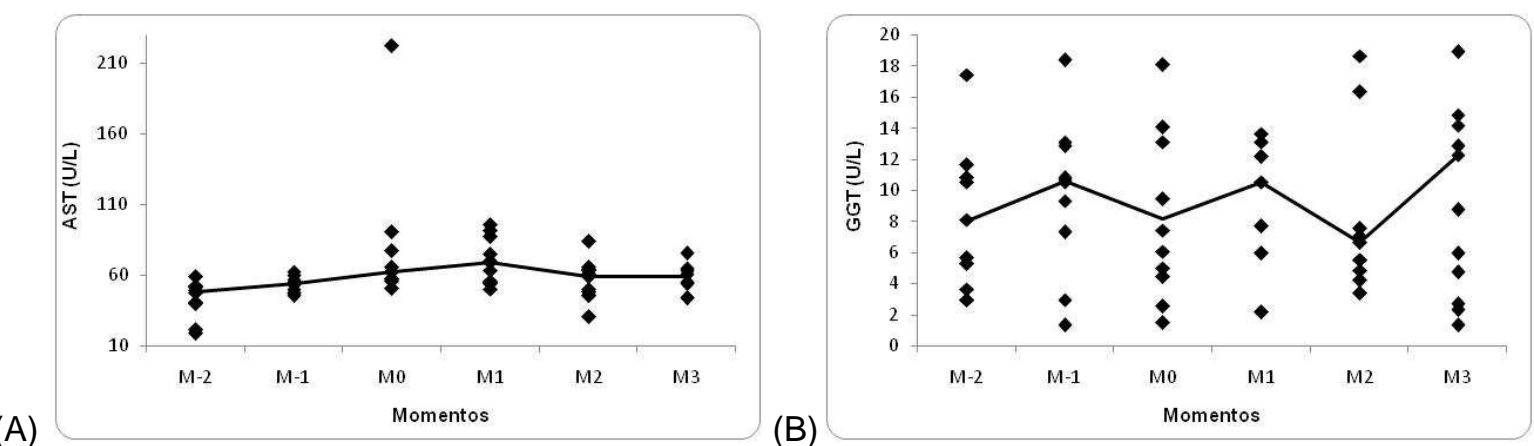

Fonte: (BALDACIM, 2013)

Legenda: AST - Aspartato aminotransferase; GGT - Gama glutamiltransferase; M-2: $2^{\circ}$ semana pré-parto; $\mathrm{M}-1$ : $1^{\circ}$ semana pré-parto; M0: dia do parto; $\mathrm{M} 1$; $1^{\circ}$ semana pós-parto; $\mathrm{M} 2$ : $2^{\circ}$ semana pós-parto; M3: $3^{\circ}$ semana pós-parto.

\subsection{METABOLISMO DO CÁLCIO}

Os valores séricos totais e ionizáveis do cálcio estão dispostos na tabela $7 \mathrm{e}$ figura 12, observando diferenças entre os momentos $(P<0,05)$. Os valores de cálcio total e ionizável apresentaram menor valor no M0. Foi possível detectar diferenças nos teores séricos de cálcio total do $\mathrm{M}-1$ em relação aos demais momentos deste estudo ( $P<0,003)$; $M 0$ também apresentou diferença em relação ao $M 3(P=0,002)$.

$\mathrm{O}$ cálcio ionizável apresentou diferenças entre $\mathrm{M}-1$ e $\mathrm{M} 0$ e demais momentos do pós-parto $(P<0,003)$. 
Tabela 8 - Cálcio total e ionizável estimado no soro sanguíneo de vacas Holandesas no período de transição - São Paulo - 2013

\begin{tabular}{|c|c|c|c|c|c|c|c|c|}
\hline & \multicolumn{8}{|c|}{ Valores do Cálcio no período de transição (mg/dL) } \\
\hline & & $M-2$ & $M-1$ & MO & M1 & M2 & M3 & Valor de $p$ \\
\hline \multirow{5}{*}{$\begin{array}{l}\text { Cálcio } \\
\text { Total } \\
\text { (mg/L) }\end{array}$} & Média & 80,0 & 94,1 & 79,2 & 80,1 & 80,5 & 88,3 & \multirow{5}{*}{$0.000^{*}$} \\
\hline & Mediana & 89,0 & 95,0 & 81,0 & 83,5 & 83,0 & 89,0 & \\
\hline & $\begin{array}{l}\text { Desvio } \\
\text { Padrão }\end{array}$ & 19,4 & 3,1 & 7,1 & 14,0 & 12,5 & 3,9 & \\
\hline & Mínimo & 43,0 & 87,0 & 69,0 & 39,0 & 47,0 & 82,0 & \\
\hline & Maximo & 98,0 & 98,0 & 89,0 & 95,0 & 91,0 & 95,0 & \\
\hline \multirow{5}{*}{$\begin{array}{c}\text { Cálcio } \\
\text { lonizável } \\
\text { (mg/L) }\end{array}$} & Média & 36,6 & 43,6 & 36,9 & 36,8 & 36,1 & 37,9 & \multirow{5}{*}{$0.000^{*}$} \\
\hline & Mediana & 39,9 & 43,2 & 36,5 & 38,0 & 37,9 & 38,6 & \\
\hline & $\begin{array}{l}\text { Desvio } \\
\text { Padrão }\end{array}$ & 9,8 & 2,8 & 4,5 & 6,4 & 6,1 & 2,4 & \\
\hline & Mínimo & 17,0 & 40,0 & 30,0 & 18,0 & 21,0 & 34,0 & \\
\hline & Maximo & 47,0 & 48,0 & 43,0 & 45,0 & 43,0 & 42,0 & \\
\hline
\end{tabular}

Fonte: (BALDACIM, 2013)

Legenda: * Diferenças significativas $(p \leq 0.05)$; $M-2: 2^{\circ}$ semana pré-parto; $M-1$ : $1^{\circ}$ semana pré-parto; M0: dia do parto; M1; $1^{\circ}$ semana pós-parto; M2: $2^{\circ}$ semana pós-parto; M3: $3^{\circ}$ semana pós-parto.

Figura 12 - Cálcio total e ionizável no soro de vacas Holandesas no período de transição São Paulo - 2013

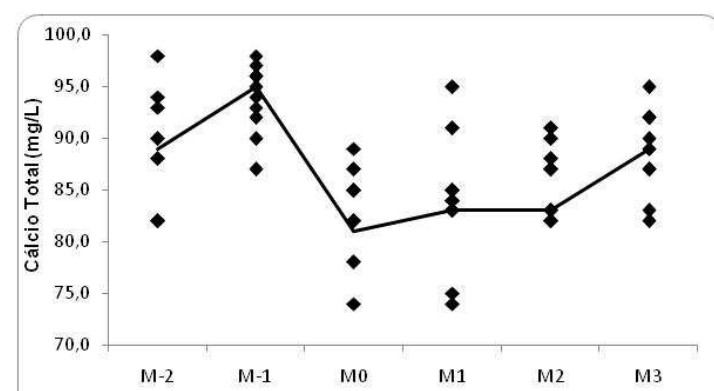

(A)

Fonte: (BALDACIM, 2013)

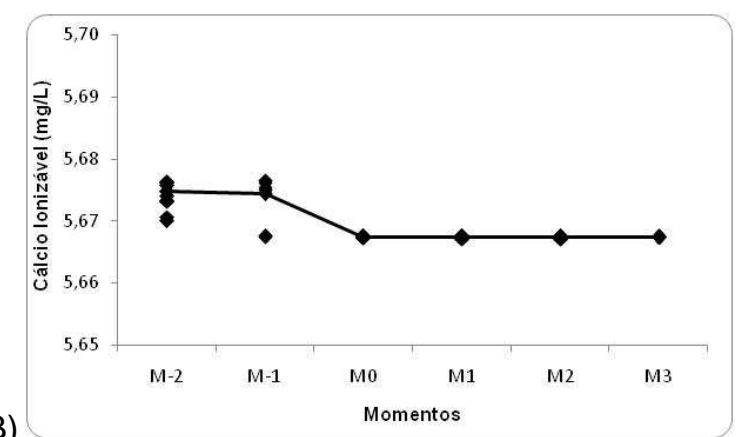

(B)

Legenda: $M-2: 2^{\circ}$ semana pré-parto; $M-1$ : $1^{\circ}$ semana pré-parto; M0: dia do parto; $M 1 ; 1^{\circ}$ semana pós-parto; $M 2: 2^{\circ}$ semana pós-parto; M3: $3^{\circ}$ semana pós-parto. 
Os valores absolutos e frequências de animais apresentando teores de cálcio discordantes dos intervalos de referência estabelecidos na literatura por Goff (2004) (ponto de corte $=85,0 \mathrm{mg} / \mathrm{L}$ ) estão dispostos na tabela 8 e figura 13 .

Tabela 9 - Número (N) e frequências (\%) de vacas Holandesas no período de transição que apresentaram valores de cálcio total $(\mathrm{mg} / \mathrm{dL})$ a baixo dos valores de referencia estabelecidos para vacas em lactação - São Paulo $-2013$

\begin{tabular}{|c|c|c|}
\hline Momentos & Variáveis & $\begin{array}{c}\text { Cálcio } \\
\text { (<85,0 mg/L) }\end{array}$ \\
\hline$M-2(n=11)$ & $\begin{array}{l}\mathrm{N} . \\
\%\end{array}$ & $\begin{array}{c}5,0 \\
45,5\end{array}$ \\
\hline$M-1 \quad(n=12)$ & $\begin{array}{l}\mathrm{N} . \\
\%\end{array}$ & $\begin{array}{l}0,0 \\
0,0\end{array}$ \\
\hline $\mathrm{MO}(\mathrm{n}=12)$ & $\begin{array}{l}N . \\
\%\end{array}$ & $\begin{array}{c}8,0 \\
66,7 \\
\end{array}$ \\
\hline M1 $(n=12)$ & $\begin{array}{l}\mathrm{N} . \\
\%\end{array}$ & $\begin{array}{c}8,0 \\
66,7\end{array}$ \\
\hline M2 $(n=13)$ & $\begin{array}{l}N . \\
\%\end{array}$ & $\begin{array}{c}7,0 \\
53,8 \\
\end{array}$ \\
\hline M3 $(n=13)$ & $\begin{array}{l}\mathrm{N} . \\
\%\end{array}$ & $\begin{array}{c}3,0 \\
23,1 \\
\end{array}$ \\
\hline
\end{tabular}
referência (GOFF, 2004).

Legenda: $M-2: 2^{\circ}$ semana pré-parto; $M-1: 1^{\circ}$ semana pré-parto; M0: dia do parto; M1; $1^{\circ}$ semana pós-parto; $M 2: 2^{\circ}$ semana pós-parto; M3: $3^{\circ}$ semana pós-parto. 
Figura 13 - Frequências (\%) de vacas Holandesas que apresentaram hipocalcemia inaparente $(<85,0 \mathrm{mg} / \mathrm{L})$ no período de transição - São Paulo - 2013

\section{Hipocalcemia}

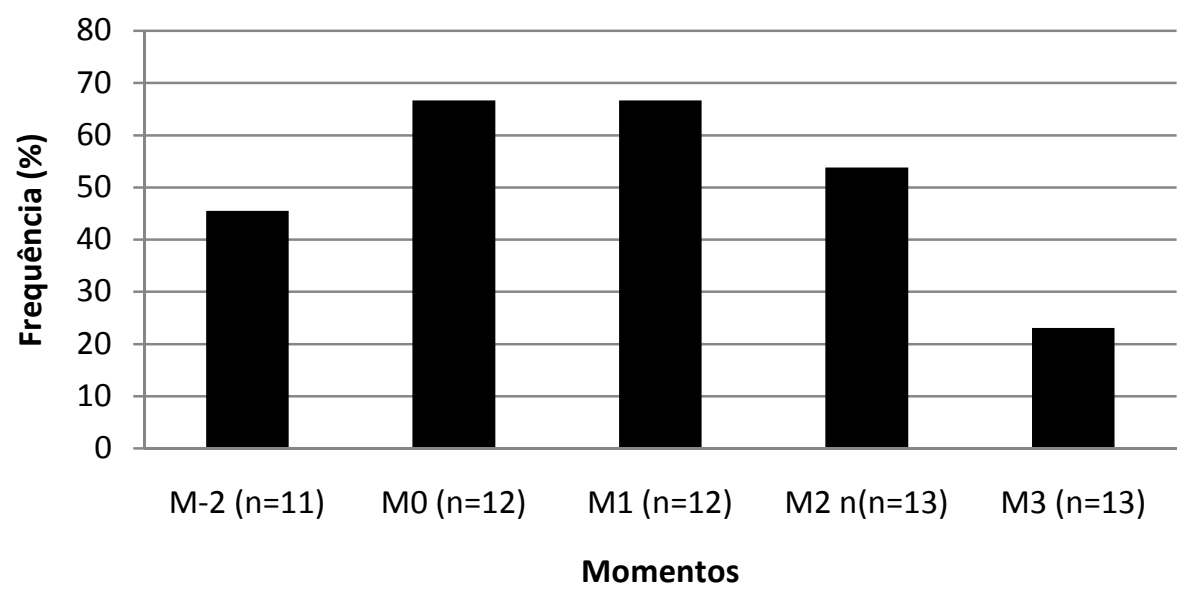

Fonte: (BALDACIM, 2013)

Legenda: $\mathrm{M}-2$ : $2^{\circ}$ semana pré-parto; $\mathrm{M}-1$ : $1^{\circ}$ semana pré-parto; M0: dia do parto; $\mathrm{M} 1 ; 1^{\circ}$ semana pós-parto; $\mathrm{M} 2: 2^{\circ}$ semana pós-parto; $\mathrm{M} 3: 3^{\circ}$ semana pós-parto. 


\subsection{RESPOSTA IMUNE CELULAR}

Abaixo serão apresentados os resultados referentes aos parâmetros utilizados na avaliação da resposta imune celular.

\subsubsection{Leucograma}

O tópico abaixo apresenta os dados obtidos na avaliação do leucograma.

\subsubsection{Leucócitos totais e mononucleares}

Os valores de leucócitos totais e mononucleares estão dispostos na tabela 9 e figura 14.

Leucócitos totais apresentaram oscilações durante o período de transição $(P=0,001)$. Foi possível observar aumento do pré-parto ao parto, momento no qual foi encontrado pico máximo, com decréscimo dos valores nos momentos subsequentes, porém não foi possível detectar diferenças pelo teste de post hoc $(P>0,003)$.

Os valores absolutos e relativos de linfócitos obtidos pela análise do leucograma não apresentaram variações no período de transição ( $P=0,062)$.

Os valores relativos e absolutos dos monócitos apresentaram diferença ao longo do período estudado. No pré-parto ( $\mathrm{M}-1)$ os monócitos apresentaram em maior proporção e quantidade e nos momentos subsequentes sua quantidade foi reduzindo, porem não foi possível detectar diferenças pelo teste post hoc $(P>0,003)$. 
Tabela 10 - Valores de leucócitos totais, linfócitos relativos (\%) e absolutos e monócitos relativos (\%) e absolutos no sangue de vacas Holandesas no período de transição - São Paulo - 2013

\begin{tabular}{|c|c|c|c|c|c|c|c|c|}
\hline \multirow[b]{2}{*}{ Parâmetros } & \multirow[b]{2}{*}{ Variáveis } & \multicolumn{5}{|c|}{ Momentos } & \multirow[b]{2}{*}{ M3 } & \multirow[b]{2}{*}{ Significância } \\
\hline & & $M-2$ & $\mathrm{M}-1$ & MO & M1 & M2 & & \\
\hline \multirow{5}{*}{$\begin{array}{c}\text { Leucócitos } \\
\text { totais } \\
\left(10^{3} / \mu \mathrm{L}\right)\end{array}$} & Média & 14,26 & 16,16 & 24,06 & 12,50 & 14,55 & 14,78 & \multirow{5}{*}{$0,001^{*}$} \\
\hline & Mediana & 12,80 & 12,80 & 21,55 & 11,20 & 11,10 & 12,20 & \\
\hline & $\begin{array}{l}\text { Desvio } \\
\text { Padrão }\end{array}$ & 7,20 & 8,96 & 12,96 & 5,74 & 9,01 & 7,92 & \\
\hline & Mínimo & 6,10 & 7,80 & 10,20 & 5,30 & 7,00 & 7,60 & \\
\hline & Maximo & 30,80 & 37,10 & 54,40 & 27,10 & 37,60 & 35,00 & \\
\hline \multirow{5}{*}{$\begin{array}{l}\text { Linfócitos } \\
\text { relativos } \\
(\%)\end{array}$} & Média & 59,00 & 57,40 & 52,10 & 70,80 & 69,80 & 67,00 & \multirow{5}{*}{0,062} \\
\hline & Mediana & 54,00 & 61,00 & 56,00 & 74,00 & 68,00 & 63,00 & \\
\hline & $\begin{array}{l}\text { Desvio } \\
\text { Padrão }\end{array}$ & 14,20 & 13,10 & 18,80 & 18,10 & 18,90 & 12,50 & \\
\hline & Mínimo & 42,00 & 32,00 & 28,00 & 29,00 & 23,00 & 44,00 & \\
\hline & Maximo & 88,00 & 78,00 & 77,00 & 94,00 & 91,00 & 88,00 & \\
\hline \multirow{5}{*}{$\begin{array}{l}\text { Linfócitos } \\
\text { absolutos } \\
\left(10^{3} / \mu \mathrm{L}\right)\end{array}$} & Média & 9,19 & 9,86 & 12,21 & 9,25 & 9,87 & 10,40 & \multirow{5}{*}{0,644} \\
\hline & Mediana & 6,78 & 7,25 & 7,85 & 7,74 & 6,57 & 6,83 & \\
\hline & $\begin{array}{l}\text { Desvio } \\
\text { Padrão }\end{array}$ & 7,35 & 7,63 & 8,44 & 5,99 & 7,03 & 7,47 & \\
\hline & Mínimo & 3,05 & 4,09 & 4,55 & 2,65 & 4,76 & 5,16 & \\
\hline & Maximo & 27,10 & 26,71 & 32,30 & 24,66 & 27,54 & 29,05 & \\
\hline \multirow{5}{*}{$\begin{array}{c}\text { Monócitos } \\
(\%)\end{array}$} & Média & 1,85 & 2,77 & 2,36 & 1,31 & 0,54 & 0,77 & \multirow{5}{*}{$0,014^{*}$} \\
\hline & Mediana & 1,00 & 3,00 & 2,00 & 1,00 & 0,00 & 0,00 & \\
\hline & $\begin{array}{l}\text { Desvio } \\
\text { Padrão }\end{array}$ & 2,15 & 2,20 & 1,03 & 2,00 & 1,12 & 1,17 & \\
\hline & Mínimo & 0,00 & 0,00 & 1,00 & 0,00 & 0,00 & 0,00 & \\
\hline & Maximo & 7,00 & 6,00 & 4,00 & 6,00 & 3,00 & 4,00 & \\
\hline \multirow{3}{*}{$\begin{array}{l}\text { Monócitos } \\
\text { Absolutos } \\
\left(\times 10^{3} \mu \mathrm{L}\right)\end{array}$} & Média & 0,32 & 0,55 & 0,36 & 0,24 & 0,04 & 0,09 & \multirow{3}{*}{$0,009^{*}$} \\
\hline & Mediana & 0,15 & 0,35 & 0,28 & 0,05 & 0,00 & 0,00 & \\
\hline & $\begin{array}{l}\text { Desvio } \\
\text { Padrão }\end{array}$ & 0,38 & 0,66 & 0,25 & 0,57 & 0,09 & 0,14 & \\
\hline
\end{tabular}

Fonte: (BALDACIM, 2013)

Legenda: *Valor significativo ( $\mathrm{p} \leq 0.05$ ); $\mathrm{M}-2: 2^{\circ}$ semana pré-parto; $\mathrm{M}-1$ : $1^{\circ}$ semana pré-parto; $\mathrm{M} 0$ : dia do parto; $\mathrm{M} 1 ; 1^{\circ}$ semana pós-parto; $\mathrm{M} 2: 2^{\circ}$ semana pós-parto; M3: $3^{\circ}$ semana pós-parto. 
Figura 14 - Valores de leucócitos totais (células/ $\mu \mathrm{L}$ ) (A), linfócitos relativos (\%) (B) e absolutos (células $/ \mu \mathrm{L}$ ) (C), monócitos relativo (\%) (D) e absoluto (E) no sangue de vacas Holandesas no período de transição - São Paulo - 2013

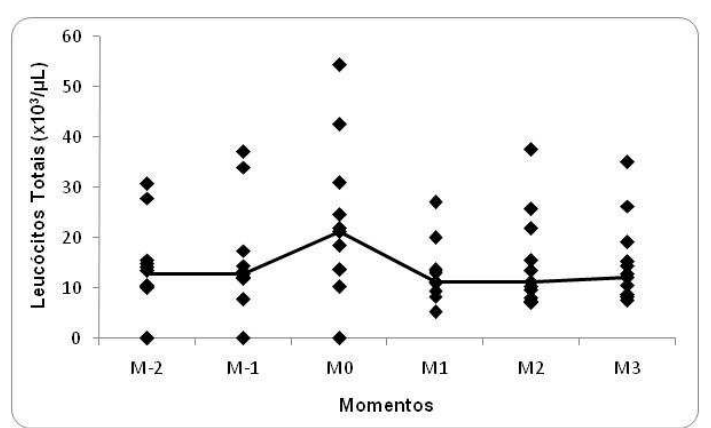

(A)

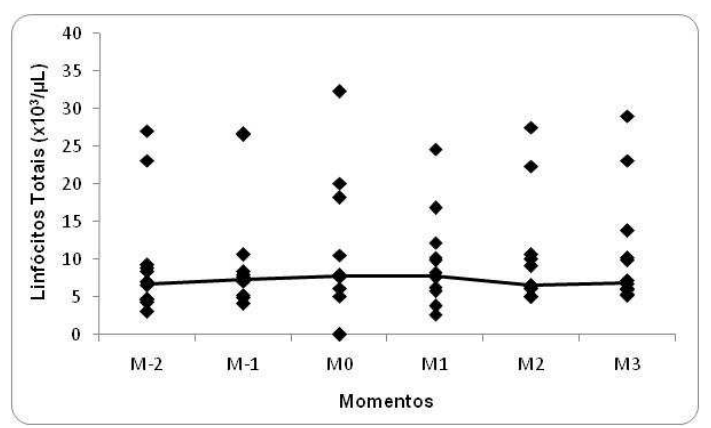

(C)

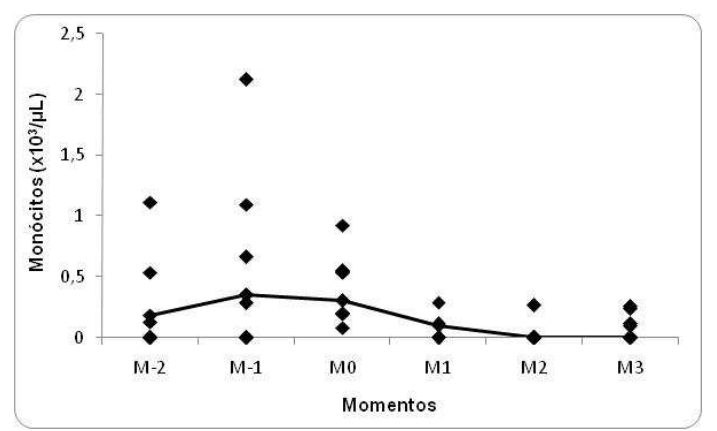

(E)

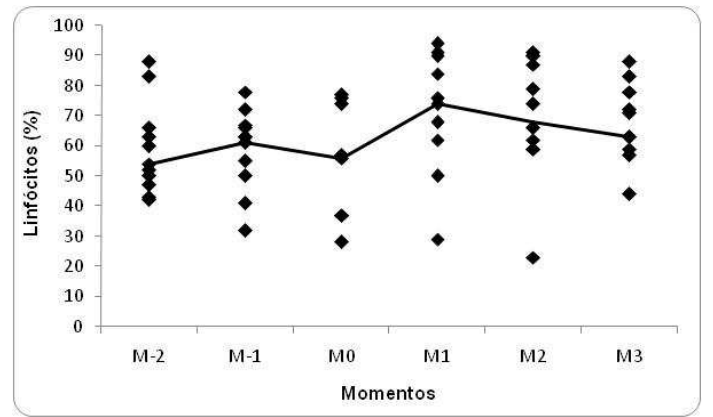

(B)

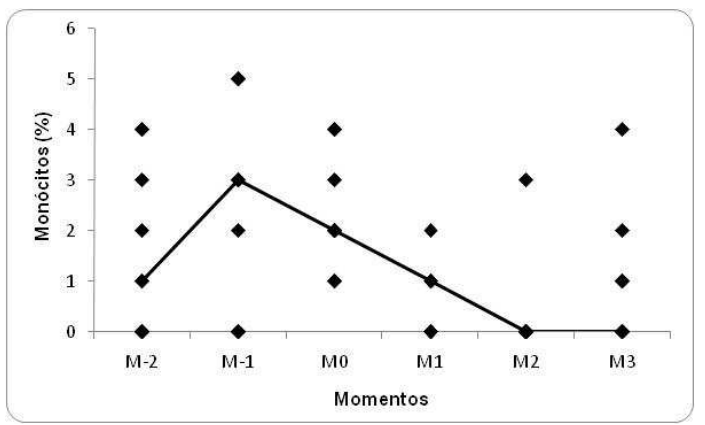

(D) 


\subsubsection{Citometria de fluxo}

Abaixo serão apresentados dados obtidos a partir dos ensaios analisados por citometria de fluxo.

\subsubsection{Subpopulações de linfócitos}

Foram avaliadas as proporções e valores absolutos de linfócitos $B\left(C D 21^{+}\right)$e $\mathrm{T}\left(\mathrm{CD}^{+}\right)$e suas subpopulações auxiliar $\mathrm{CD}^{+}$e citotóxico $\mathrm{CD} 8^{+}$, por meio da técnica de citometria de fluxo. Os valores estão apresentados em valores relativos e absolutos estimados a partir do número total de linfócitos obtidos a partir da contagem diferencial de leucócitos pela leitura dos esfregaços sanguíneos.

\subsection{Linfócitos $B\left(C D 21^{+}\right)$}

Os valores absolutos e proporção de células $\mathrm{CD} 21^{+}$estão dispostos na tabela 10 e figura 15. Não foi possível detectar variações ao longo do tempo para as células $C D 21^{+}(P>0,05)$. No entanto, a análise descritiva dos dados revelou que os valores medianos relativos de linfócitos $B$ no pós-parto (M2 e M3) foram maiores que aqueles do pré-parto e parto. Os valores absolutos de células CD21+ apresentaramse estáveis durante o período de estudo, porém o pico máximo foi obtido no pósparto (M2) (Tabela 10). 
Tabela 11 - Valores absolutos (células/ $\mu \mathrm{L}$ ) e proporções (\%) de linfócitos $\mathrm{CD} 21^{+}$no sangue de vacas Holandesas no período de transição - São Paulo - 2013

\begin{tabular}{|c|c|c|c|c|c|c|c|c|}
\hline & & \multicolumn{7}{|c|}{ Subpopulações de linfócitos $\left(\mathrm{CD} 21^{+}\right)$} \\
\hline & & M-2 & $M-1$ & MO & M1 & M2 & M3 & Valor de $p$ \\
\hline \multirow{5}{*}{$\begin{array}{c}\text { Células CD21+ } \\
(\%)\end{array}$} & Média & 49,58 & 43,58 & 45,91 & 46,76 & 59,69 & 60,26 & \multirow{5}{*}{0,102} \\
\hline & Mediana & 46,44 & 45,69 & 45,78 & 46,64 & 60,86 & 54,96 & \\
\hline & $\begin{array}{l}\text { Desvio } \\
\text { Padrão }\end{array}$ & 22,69 & 11,34 & 18,06 & 19,41 & 21,02 & 16,25 & \\
\hline & Mínimo & 15,52 & 24,39 & 19,87 & 18,79 & 14,52 & 39,51 & \\
\hline & Maximo & 87,12 & 59,22 & 85,21 & 89,68 & 84,70 & 87,83 & \\
\hline \multirow{5}{*}{$\begin{array}{l}\text { Células CD } 21^{+} \\
\left(\times 10^{3} \text { céls } / \mu \mathrm{L}\right)\end{array}$} & Média & 5,70 & 5,07 & 6,58 & 4,47 & 6,64 & 7,10 & \multirow{5}{*}{0,064} \\
\hline & Mediana & 2,82 & 3,82 & 3,80 & 3,15 & 3,92 & 3,71 & \\
\hline & $\begin{array}{l}\text { Desvio } \\
\text { Padrão }\end{array}$ & 6,53 & 4,93 & 7,41 & 3,52 & 6,62 & 7,21 & \\
\hline & Mínimo & 0,91 & 1,19 & 1,41 & 0,78 & 0,72 & 2,14 & \\
\hline & Maximo & 23,61 & 15,81 & 27,52 & 10,97 & 23,33 & 24,98 & \\
\hline
\end{tabular}

Fonte: (BALDACIM, 2013)

Legenda: $M-2: 2^{\circ}$ semana pré-parto; $M-1$ : $1^{\circ}$ semana pré-parto; M0: dia do parto; $M 1 ; 1^{\circ}$ semana pós-parto; M2: $2^{\circ}$ semana pós-parto; M3: $3^{\circ}$ semana pós-parto.

Figura 15 - Valores absolutos (células/ $\mu \mathrm{L}$ ) e proporções (\%) de células CD21+ no sangue de vacas Holandesas no período de transição - São Paulo - 2013

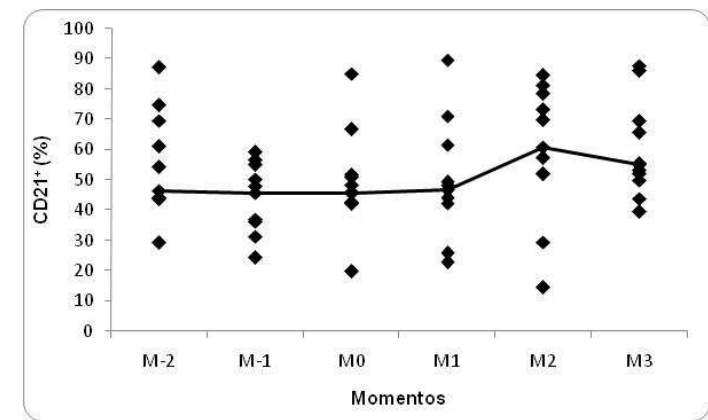

Fonte: (BALDACIM, 2013)

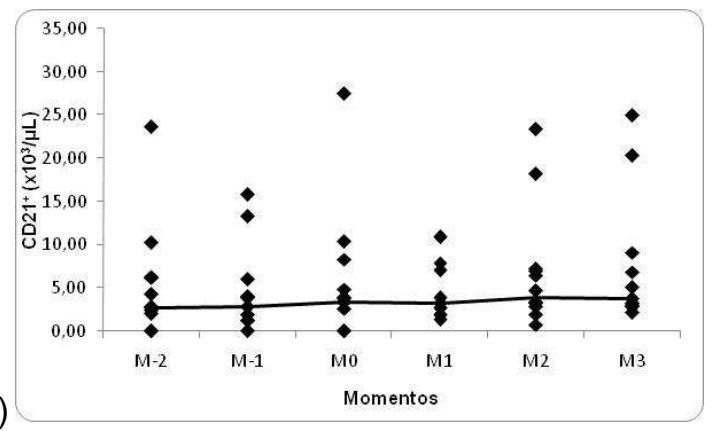

(B)

Legendas: $M-2$ : $2^{\circ}$ semana pré-parto; $M-1: 1^{\circ}$ semana pré-parto; M0: dia do parto; $M 1 ; 1^{\circ}$ semana pós-parto; M2: $2^{\circ}$ semana pós-parto; M3: $3^{\circ}$ semana pós-parto. 


\subsection{Linfócitos $T\left(C D 3^{+}\right)$e suas subpopulações}

Os valores absolutos e proporções dos linfócitos $\mathrm{T}\left(\mathrm{CD}^{+}\right)$e suas subpopulações estão dispostas na tabela 11 e figura 16.

Os valores absolutos e proporções de células $\mathrm{T} \mathrm{CD3}^{+}$e sua subpopulação de linfócitos citotóxico $\left(\mathrm{CD}^{+}{ }^{+} \mathrm{CD} 8^{+}\right)$não apresentaram variação ao longo do tempo $(P>0,05)$, porém foi possível detectar variações nas proporções (\%) de linfócito $T$ auxiliares $\left(\mathrm{CD}^{+} \mathrm{CD}^{+}\right)(\mathrm{P}=0,009)$.

Foi possível observar diminuição marcante da proporção de linfócitos $T$ auxiliares (CD4) nos momentos M-1 e M1, obtendo picos máximos nos momentos M2 e M3. Não foi possível comprovar diferenças entre os momentos usando o teste post hoc. 
Tabela 12 - Valores absolutos $\left(\times 10^{3}\right.$ céls/ $\left.\mu \mathrm{L}\right)$ e proporções (\%) de linfócitos $\mathrm{T}\left(\mathrm{CD}^{+}\right)$e suas subpopulações de linfócito $\mathrm{T}$ auxiliar $\left(\mathrm{CD}^{+} \mathrm{CD4}^{+}\right)$e linfócitos citotóxicas $\left(\mathrm{CD} 4^{+} \mathrm{CD} 8^{+}\right)$no sangue de vacas Holandesas no período de transição - São Paulo - 2013

\begin{tabular}{|c|c|c|c|c|c|c|c|c|}
\hline \multicolumn{9}{|c|}{ Subpopulações de Linfócitos } \\
\hline & & $M-2$ & $M-1$ & MO & M1 & M2 & M3 & Valor de $\mathrm{P}$ \\
\hline \multirow{5}{*}{$\mathrm{CD}^{+}(\%)$} & Média & 38,35 & 39,34 & 40,77 & 37,17 & 33,88 & 38,78 & \multirow{5}{*}{0,783} \\
\hline & Mediana & 38,24 & 36,61 & 43,22 & 39,83 & 33,23 & 42,39 & \\
\hline & Desvio & 12,35 & 12,95 & 13,56 & 17,10 & 14,59 & 13,65 & \\
\hline & Mínimo & 20,53 & 19,95 & 19,94 & 3,59 & 5,62 & 17,95 & \\
\hline & Máximo & 61,46 & 61,02 & 55,79 & 60,10 & 56,83 & 57,90 & \\
\hline \multirow{5}{*}{$\begin{array}{c}\mathrm{CD}^{+} \\
\left(\times 10^{3} \text { céls } / \mu \mathrm{L}\right)\end{array}$} & Média & 3,30 & 3,33 & 4,77 & 3,14 & 2,99 & 3,47 & \multirow{5}{*}{0,864} \\
\hline & Mediana & 2,71 & 2,78 & 3,73 & 3,03 & 3,15 & 3,09 & \\
\hline & $\begin{array}{l}\text { Desvio } \\
\text { Padrão }\end{array}$ & 1,45 & 1,51 & 2,88 & 1,73 & 1,46 & 1,46 & \\
\hline & Mínimo & 1,89 & 1,93 & 2,12 & 0,22 & 0,35 & 1,06 & \\
\hline & Máximo & 6,87 & 7,13 & 11,21 & 6,15 & 5,28 & 7,07 & \\
\hline \multirow{5}{*}{$\begin{array}{l}\mathrm{CD}^{+}{ }^{\mathrm{CD}} 4^{+} \\
(\%)\end{array}$} & Média & 8,50 & 6,61 & 9,08 & 7,36 & 11,22 & 12,21 & \multirow{5}{*}{$0,009^{*}$} \\
\hline & Mediana & 7,93 & 4,79 & 9,05 & 5,69 & 11,22 & 11,73 & \\
\hline & $\begin{array}{l}\text { Desvio } \\
\text { Padrão }\end{array}$ & 4,81 & 5,59 & 4,09 & 4,62 & 5,46 & 6,11 & \\
\hline & Mínimo & 1,23 & 0,53 & 3,41 & 3,21 & 3,83 & 5,60 & \\
\hline & Máximo & 16,13 & 16,95 & 16,41 & 17,36 & 20,27 & 24,30 & \\
\hline \multirow{5}{*}{$\begin{array}{c}\mathrm{CD3}^{+} \mathrm{CD} 4^{+} \\
\left(\times 10^{3} \text { céls } / \mu \mathrm{L}\right)\end{array}$} & Média & 0,66 & 0,53 & 1,01 & 0,60 & 0,86 & 1,04 & \multirow{5}{*}{0,071} \\
\hline & Mediana & 0,61 & 0,46 & 0,83 & 0,63 & 0,83 & 1,01 & \\
\hline & $\begin{array}{l}\text { Desvio } \\
\text { Padrão }\end{array}$ & 0,32 & 0,42 & 0,58 & 0,30 & 0,44 & 0,41 & \\
\hline & Mínimo & 0,18 & 0,03 & 0,29 & 0,09 & 0,00 & 0,33 & \\
\hline & Máximo & 1,12 & 1,42 & 2,27 & 1,05 & 1,55 & 1,72 & \\
\hline \multirow{5}{*}{$\begin{array}{c}\mathrm{CD}^{+} \mathrm{CD}^{+} \\
(\%)\end{array}$} & Média & 9,19 & 10,77 & 11,55 & 10,15 & 11,44 & 10,68 & \multirow{5}{*}{0,074} \\
\hline & Mediana & 7,32 & 9,92 & 10,28 & 8,44 & 10,96 & 8,58 & \\
\hline & $\begin{array}{l}\text { Desvio } \\
\text { Padrão }\end{array}$ & 4,38 & 3,93 & 5,99 & 5,33 & 2,94 & 5,31 & \\
\hline & Mínimo & 4,56 & 6,21 & 4,69 & 4,78 & 7,58 & 4,76 & \\
\hline & Máximo & 16,79 & 17,38 & 23,72 & 23,30 & 18,11 & 26,00 & \\
\hline \multirow{5}{*}{$\begin{array}{c}\mathrm{CD}^{+}{ }^{+} \mathrm{CD} 8^{+} \\
\left(\times 10^{3} \text { céls } / \mu \mathrm{L}\right)\end{array}$} & Média & 0,82 & 0,95 & 1,48 & 0,89 & 1,10 & 0,97 & \multirow{5}{*}{0,311} \\
\hline & Mediana & 0,71 & 0,80 & 1,11 & 0,83 & 0,79 & 0,80 & \\
\hline & $\begin{array}{l}\text { Desvio } \\
\text { Padrão }\end{array}$ & 0,47 & 0,50 & 1,30 & 0,54 & 0,75 & 0,51 & \\
\hline & Mínimo & 0,29 & 0,36 & 0,21 & 0,16 & 0,40 & 0,44 & \\
\hline & Máximo & 1,69 & 1,89 & 4,77 & 1,80 & 3,01 & 1,89 & \\
\hline
\end{tabular}

Fonte: (BALDACIM, 2013)

Legenda: * Valores com diferenças significativas; M-2: $2^{\circ}$ semana pré-parto; M-1: $1^{\circ}$ semana pré-parto; M0: dia do parto; $\mathrm{M} 1 ; 1^{\circ}$ semana pós-parto; M2: $2^{\circ}$ semana pós-parto; M3: $3^{\circ}$ semana pós-parto. 
Figura 16 - Valores absolutos $\left(\times 10^{3}\right.$ céls/ $\left.\mu \mathrm{L}\right)$ e proporções (\%) de linfócitos $\mathrm{T}$ e suas subpopulações auxiliar $\left(\mathrm{CD}^{+} \mathrm{CD} 4^{+}\right)$e citotóxica $\left(\mathrm{CD}^{+} \mathrm{CD} 8^{+}\right)$no sangue de vacas Holandesas no período de transição - São Paulo - 2013

(A)
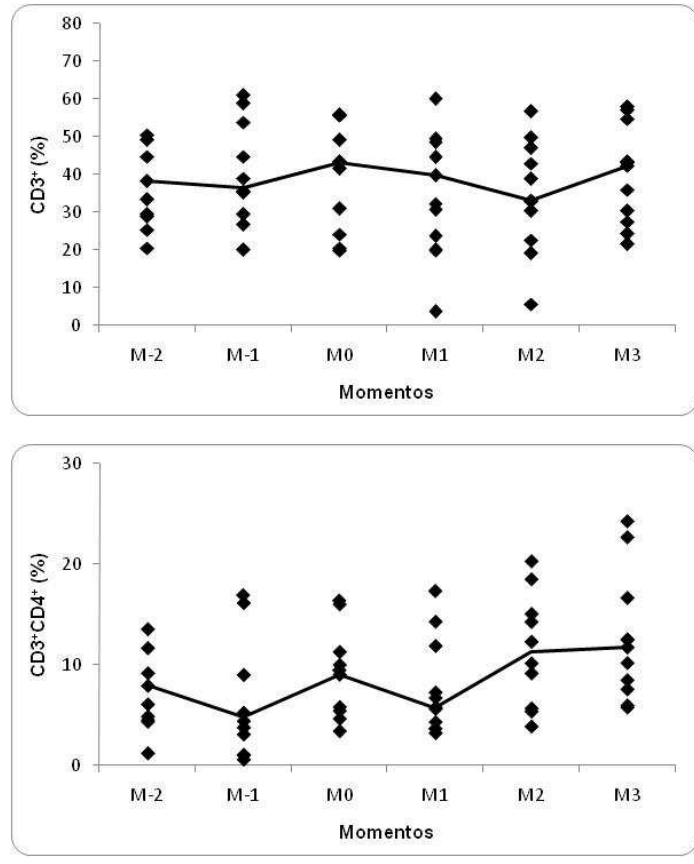

(C)

(E)

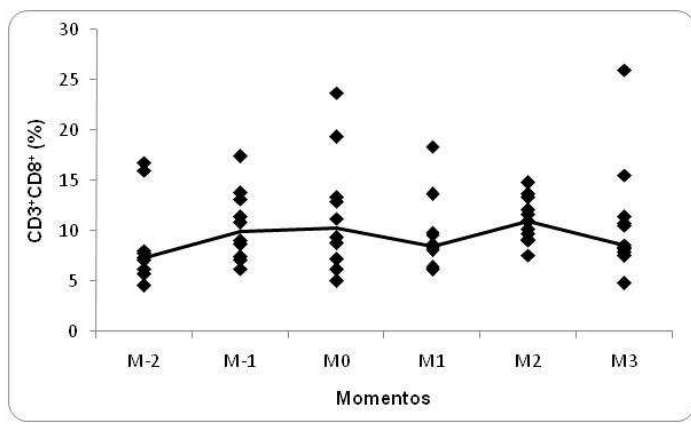

(B)
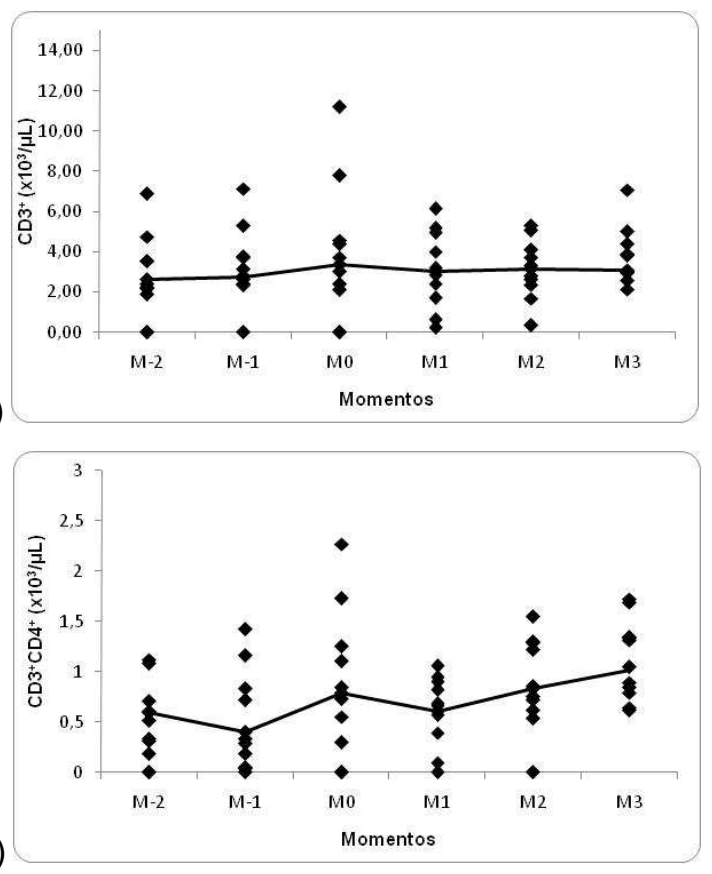

(D)

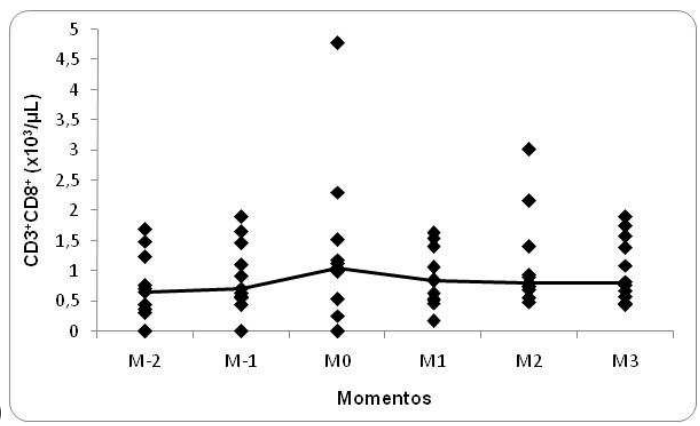

Fonte: (BALDACIM, 2013)

Legenda: $M-2: 2^{\circ}$ semana pré-parto; $M-1: 1^{\circ}$ semana pré-parto; M0: dia do parto; $M 1 ; 1^{\circ}$ semana pós-parto; M2: $2^{\circ}$ semana pós-parto; M3: $3^{\circ}$ semana pós-parto. 


\subsection{RESPOSTA SOROLÓGICA PARA O VÍRUS DA LEUCOSE ENZOOTICA BOVINA}

Em função do elevado número de linfócitos, em relação aos valores de referencia encontrados para as vacas Holandesas, desde o início deste experimento, optou-se pela realização de testes sorológicos para o Vírus da Leucose Enzootica Bovina por imunodifusão em gel de Ágar (EDGA) e teste imunoenzimático. Os resultados dos testes sorológicos estão demonstrados na tabela 12, no qual foi possível obter frequências de 69,23 no M-3, 46,15 no M0, e $69,23 \%$ no M3 para o IDGA, e 92,30\% nos momentos M-3, M0 e M3 para o teste imunoenzimático. 
Tabela 13 - Resultado dos testes sorológicos (Imunodifusão em gel de Agar e Teste imunoenzimático) realizado em vacas Holandesas no período de transição - São Paulo - 2013

\begin{tabular}{|c|c|c|c|}
\hline & \multicolumn{3}{|c|}{ IDGA } \\
\hline & M-3 & M0 & M3 \\
\hline 1429 & Reagente & Não reagente & Reagente \\
\hline 1332 & Reagente & Reagente & Reagente \\
\hline 1356 & Reagente & Não reagente & Reagente \\
\hline 1384 & Reagente & Reagente & Reagente \\
\hline 1333 & Reagente & Reagente & Reagente \\
\hline 1445 & Não reagente & Não reagente & Não reagente \\
\hline 4410 & Reagente & Reagente & Reagente \\
\hline 1447 & Não realizou & Não reagente & Não reagente \\
\hline 1478 & Reagente & Reagente & Reagente \\
\hline 1453 & Não reagente & Não reagente & Não reagente \\
\hline 1433 & Reagente & Reagente & Reagente \\
\hline 1437 & Não reagente & Não reagente & Reagente \\
\hline \multirow[t]{3}{*}{4409} & Reagente & Não reagente & Não reagente \\
\hline & \multicolumn{3}{|c|}{ ELISA } \\
\hline & M-3 & M0 & M3 \\
\hline 1429 & Reagente & Reagente & Reagente \\
\hline 1332 & Reagente & Reagente & Reagente \\
\hline 1356 & Reagente & Reagente & Reagente \\
\hline 1384 & Reagente & Reagente & Reagente \\
\hline 1333 & Reagente & Reagente & Reagente \\
\hline 1445 & Reagente & Reagente & Reagente \\
\hline 4410 & Reagente & Reagente & Reagente \\
\hline 1447 & Reagente & Reagente & Reagente \\
\hline 1478 & Reagente & Reagente & Reagente \\
\hline 1453 & Não reagente & Não reagente & Não reagente \\
\hline 1433 & Reagente & Reagente & Reagente \\
\hline 1437 & Reagente & Reagente & Reagente \\
\hline 4409 & Reagente & Reagente & Reagente \\
\hline
\end{tabular}

Fonte: (BALDACIM, 2013)

Legenda: M-3: $3^{\text {a }}$ semana pré-parto; M0: dia do parto; M3: $3^{\text {a }}$ semana pós-parto. 


\section{DISCUSSÃO}

O período de transição em vacas leiteiras é marcado por adaptações metabólicas regulados pelos mecanismos homeostáticos e homeorréticos (BAUMAN; BRUCE CURRIE, 1980). Neste período, a coordenação do metabolismo é a chave para a adaptação à lactação e diminuição das doenças metabólicas, como hipocalcemia, cetose, esteatose hepática, retenção de secundinas e deslocamento de abomaso (MULLIGAN; DOHERTY, 2008; INGVARTSEN; MOYES, 2013). Além disso, o status imunológico das vacas em transição está enfraquecido, especialmente os mecanismos da imunidade celular, predispondo às doenças infecciosas, como a mastite e metrite (MULLIGAN; DOHERTY, 2008; INGVARTSEN; MOYES, 2013). Assim, as adaptações metabólicas e imunológicas associadas à elevada ocorrência das doenças da produção no período de transição, motivaram o desenvolvimento desta pesquisa. Desta forma, esta pesquisa avaliou o perfil metabólico e a resposta imune celular, em vacas Holandesas no período de transição, criadas no estado de São Paulo.

\subsection{METABOLISMO ENERGÉTICO}

As vacas desta pesquisa apresentaram elevado escore de condição corporal (ECC) no pré-parto $(4,0)$, reduzindo para ECC equivalente à 3,0 no M1. A perda de peso observada do M-2 ao M1, provavelmente ocorreu devido ao aumento da demanda energética para manutenção fetal e início da lactação, associada à diminuição da ingestão de matéria seca. A diminuição do ECC do pré-parto ao pósparto também foi relatada por Busato et al. (2002) e Mouffok et al. (2013).

Mouffok et al. (2013) observaram redução do ECC de 3,04 na $6^{\circ}$ semana antes do parto para 2,77 na $6^{\circ}$ semana pós-parto $(\Delta=0,27)$. Esta pesquisa encontrou redução do ECC de 4,0 na semana $M-2$ para 3,0 na semana M1 $(\Delta=1,0)$, em seguida observou-se aumento do ECC para 3,5 na semana M3 $(\Delta=0,5)$. As diferenças na redução do ECC $(\Delta)$ entre as pesquisas do pré-parto ao pós-parto 
pode ser decorrente da condição corporal das vacas. Vacas obesas $(E C C \geq 4)$ apresentam perda de peso mais intensa (LAGO et al., 2001).

Em relação ao metabolismo energético, foi possível observar aumento nos valores de NEFA e BHB, especialmente no dia da parição e $1^{\circ}$ semana pós-parto, associada a diminuição nos teores de triglicérides, colesterol e IGF-I.

As variações dos indicadores energéticos obtidos nesta pesquisa foram concordantes com os descritos por Hammon et al. (2009) que observaram elevação nos valores plasmáticos de NEFA ( $1 \mathrm{mmol} / \mathrm{L})$ e BHB $(1,25 \mathrm{mmol} / \mathrm{L})$ a partir do parto. Este fenômeno pode ser associado à lipólise e gliconeogênese, associados aos efeitos endócrinos presentes no final da gestação e início da lactação (DRACKLEY, 1999).

A glicemia apresentou-se estável durante o período de transição, com exceção do M0, no qual foi possível observar hiperglicemia. Este fenômeno pode ser decorrente do estresse do parto, que ativa o eixo somatotrópico, e resulta na liberação do cortisol e catecolaminas, que possui efeito hiperglicemiante (PATEL et al.,1996). Hammon et al. (2009) também encontraram concentração máxima de glicose na parição $(72 \mathrm{mg} / \mathrm{dL})$.

Moreira (2013) avaliou o metabolismo energético de vacas leiteiras no período de transição, no verão, e encontrou os respectivos valores no pré-parto, parto e pósparto: de 0,04 à 0,$26 ; 0,30$; e 0,35 à $0,21 \mathrm{mmol} / \mathrm{L}$ para NEFA; $0,30-0,42 ; 0,57 ; 0,78$ $0,62 \mathrm{mmol} / \mathrm{L}$ para BHB; 45,35 à 44,$35 ; 50,69 ; 41,51-40,86 \mathrm{mg} / \mathrm{dL}$ para glicose; 43,88 à 34,$98 ; 28,69 ; 26,45$ à 25,23 mg/dL para triglicérides; 76,52 à 58,48; 50,82; 61,76$77,22 \mathrm{mg} / \mathrm{dL}$ para colesterol. Apesar destes parâmetros apresentarem oscilações semelhantes às observadas nesta pesquisa, os valores de NEFA, BHB, glicose e colesterol foram superiores aos valores observados por Moreira (2013). Este fato pode ser associado a intensidade da lipólise apresentada neste trabalho devido ao elevado ECC no pré-parto, pois as vacas acompanhadas por este autor apresentou ECC igual a 3,4 na semana -4 pré-parto.

Souza e Birgel Junior (2009) avaliaram a influência do puérperio e do póspuerpério no lipodograma (glicose, colesterol, triglicerídeos, NEFA e BHB) no soro de vacas Holandesas sadias, com produção média diária de 15 a 25 litros, avaliadas em quatro diferentes momentos: 0-10 dias pós-parto; 30-45 dias pós-parto; 45-60 dias pós-parto e mais de 60 dias pós-parto. A concentração de triglicérides $(17,82$ 
$\mathrm{mg} / \mathrm{dL})$, colesterol $(67,72 \mathrm{mg} / \mathrm{dL})$ e glicose $(53,20 \mathrm{mg} / \mathrm{dL})$ apresentaram menores valores nos primeiros 10 dias pós-parto. Ao contrário, neste momento os valores de NEFA e BHB apresentaram-se elevados (NEFA - 0,72 mmol/L e BHB - 0,32 $\mathrm{mmol} / \mathrm{L}$ ). Fato semelhante foi encontrado na presente pesquisa, porém os valores de glicose apresentaram menor valor em M2, decorrente do aumento da produção leiteira observada neste momento.

O IGF-I apresentou redução marcante no parto e pós-parto. Este resultado provavelmente ocorreu pelo desacoplamento do eixo somatotrópico observado em vacas no periparto, observando-se diminuição da expressão dos receptores de GH no fígado, mesmo na presença de elevadas concentrações do hormônio de crescimento.

A diminuição do IGF-I no pós-parto também foi relatada por Hammon et al. (2009), Laeger et al. (2014) e Nowak et al. (2014). Nowak et al. (2014) avaliaram as concentrações séricas de IGF-I em vacas no período de transição. Estes autores encontraram valores superiores aos observados nesta pesquisa: $356 \mathrm{ng} / \mathrm{mL}(-30 \mathrm{~d})$; $44,5 \mathrm{ng} / \mathrm{mL}$ (-3d); 37,5 ng/mL (+5d.); e $102 \mathrm{ng} / \mathrm{mL}$ (+28d).

Laeger et al. (2014) também encontraram valores superiores aos encontrados nesta pesquisa: $230 \mathrm{ng} / \mathrm{mL}(-20 \mathrm{~d}) ; 190 \mathrm{ng} / \mathrm{mL}(-10 \mathrm{~d}), 100 \mathrm{ng} / \mathrm{mL}$ (1d), $120 \mathrm{ng} / \mathrm{mL}$ $(+10 \mathrm{~d})$, e $130 \mathrm{ng} / \mathrm{mL}(+20 \mathrm{~d})$. Estes autores ressaltaram que os valores estão superiores aos encontrados na literatura, e acreditam que essa diferença podem estar relacionadas com a idade e raças utilizadas nos diferentes estudos.

$\mathrm{Na}$ presente pesquisa, algumas vacas menos adaptadas às alterações homeorréticas, durante o período de transição, apresentaram valores acima do ponto de corte para BHB (1.400mmol/L) sugerido por Gordon (2013).

Duas vacas apresentaram cetose na primeira semana pós-parto (M1) e, uma terceira vaca apresentou na semana M3. No primeiro caso, observou-se diminuição do ECC de 3,5 para 2,0 (Vaca 1429) e, o caso de cetose foi subsequente ao parto gemelar e distocico; a vaca 1445 apresentou redução do $\operatorname{ECC~(3,5~para~2,5),~}$ retenção de placenta e infecção uterina; e a vaca 4409 apresentava ECC 4,5 ao inicio do experimento e ECC 4,0 na semana M3, momento no qual foi observado elevados índices de BHB.

Nos dois primeiros casos, provavelmente a cetose foi manifestada pelos aumento dos requerimentos energéticos associados aos quadros clínicos. Hammom 
et al. (2006) observaram que as vacas apresentando problemas uterinos no pósparto tiveram maiores valores de NEFA e menor consumo de matéria seca nas semanas que antecederam o parto.

O terceiro caso apresentado, está relacionado à obesidade apresentada pela vaca. Segundo Edmonson et al. (1989), vacas com ECC elevada $(4-4,25)$ são mais propensas à cetose espontânea, devido ao fato de apresentarem menor consumo logo após o parto e mobilizarem mais reservas corporais.

\subsection{METABOLISMOS PROTEICO E HEPÁTICO}

Os teores de globulina obtidos nesta pesquisa foram inferiores aos intervalos de referência no M-2 ao M0 (KANEKO, 2008). Este achado pode ser associado com a colostrogênese, processo que se inicia semanas antes do parto, momento onde se observa a transferência seletiva da lgG1 sanguínea para a glândula mamaria (BLUTTER, 1983; LARSON, 1985).

Os teores de proteína sérica total e globulina se elevaram no pós-parto (M2 e M3), momento em que algumas vacas apresentavam infecções uterinas.

Observou-se diminuição nos teores séricos de albumina no pós-parto na presente pesquisa, associada às maiores concentrações de NEFA e BHB, que pode ser decorrente da redução da biossíntese hepática pela presença de corpos cetônicos nos hepatócitos (SAMANC et al., 2011). Além disso, a diminuição da ALB pode ser resultado do aumento da utilização de aminoácidos em processos de gliconeogênese no período próximo ao parto (SEAL; REYNOLDS, 1993). O aumento da atividade sérica da enzima AST, ao longo do período estudado, corrobora com esta hipótese, pois é um indicador significativo do catabolismo de proteínas e sua utilização para a gliconeogênese.

A atividade sérica das enzimas AST apresentou-se a baixo dos valores de referência estabelecidos para a espécie (FAGLIARI et al., 1998; KANEKO, 2008), mesmo apresentando aumento no parto e pós-parto. Já a GGT, seguindo como referencia os mesmo autores, apresentou-se dentro da normalidade. Moreira (2013) encontrou variações semelhantes às obtidas nesta pesquisa. Este aumento pode ser influenciado por uma maior atividade hepática e/ou catabolismo proteico, no 
processo de gliconeogênese, para suprir as necessidades energéticas impostas com inicio da lactação (SEAL; REYNOLDS, 1993).

A relação albumina:globulina é um parâmetro que auxilia na identificação de problemas hepáticos. Em lesões hepáticas crônicas observa-se redução nos teores de albumina e aumento das globulinas, que resulta em relação albumina:globulina inferior a 0,5 (BIRGEL JUNIOR et al., 2003). Nenhuma das vacas desta pesquisa apresentou relação $A L B: G L O B \leq 0,5$. Este fato, associado aos valores normais das enzimas hepáticas e albumina no pós-parto, corrobora para a afirmação que as vacas desta pesquisa não apresentaram esteatose hepática durante o período experimental.

\subsection{CÁLCIO}

No periparto, devido ao aumento da demanda por cálcio na produção láctea, dentre as doenças de produção, a hipocalcemia é uma das mais comuns (HORST, 1986; GOFF, 2008; REINHARDT et al, 2011). Além disso os valores de cálcio podem contribuir na imunidade do animal. Kimura et al. (2006) estudando vacas leiteiras que apresentaram hipocalcemia observaram uma menor resposta das células mononucleares do sangue periférico.

A diminuição do cálcio na semana pré e pós-parto foram associadas com maior risco de deslocamento de abomaso, queda na produção de leite e diminuição na taxa de prenhes na primeira inseminação artificial (CHAPINAL et al., 2011; CHAPINAL et al., 2012a; CHAPINAL et al., 2012b).

Como foi de se esperar, os menores valores séricos de cálcio total foram observados no periparto. Ortolani (1995) estudando rebanho bovino leiteiro no estado de São Paulo, relatou que a maior frequência de hipocalcemia foi nas primeiras $24 \mathrm{~h}$ pós parto, o que em parte, foi observado nesta pesquisa, pois na primeira semana pós-parto ainda observamos a mesma frequência de animais com hipocalcemia encontrado no parto $(66,7 \%)$. Nesta pesquisa, a frequência da hipocalcemia relatada leva em conta o diagnóstico laboratorial utilizando o valor de referencia da literatura (85 mg/L) (GOFF, 2004), apenas um animal apresentou hipocalcemia clinica no momento do parto. 
As concentrações de cálcio dos animais ficaram abaixo dos valores de referência no momento do parto $(81,0 \mathrm{mg} / \mathrm{L}), 1^{\text {a }}(83,5 \mathrm{mg} / \mathrm{L})$ e $2^{\mathrm{a}}(83,0 \mathrm{mg} / \mathrm{L})$ semana pós-parto, sendo o menor valor durante o parto. Porém, com exceção da última semana antes do parto, em todos os momentos alguns animais apresentaram valores de cálcio abaixo dos valores de referência.

Observando os teores de $\mathrm{Ca}$ de rebanhos de vacas leiteiras no Estado de Minas Gerais apresentados por Moreira (2013) o autor observou menor concentração no momento do parto, porem a menor média de concentração ficou dentro dos valores de referencia $(87,0 \mathrm{mg} / \mathrm{L})$. $O$ autor também relatou que a frequência dos animais apresentando hipocalcemia recidiva até 10 dias depois do parto ainda foi alta.

Os teores de cálcio podem ser influenciados pela alimentação com quantidade reduzida de vitamina $D$ que resulta em menor absorção de $\mathrm{Ca}$ no intestino (HIBBIS; CONRAD, 1983).

As exigências de Ca para uma vaca em lactação aumentam pois, em média esses animais secretam de $20 \mathrm{~g}$ a $30 \mathrm{~g}$ por dia de Ca via colostro ou leite (GOFF, 2000). Desta forma, fica evidente que o comportamento da oscilação do $\mathrm{Ca}$ encontrada por diversos autores é sempre a mesma, menor valor no periparto e que uma boa condição de manejo nutricional pode prevenir o aparecimento da hipocalcemia clínica.

\subsection{RESPOSTA IMUNE}

Esta pesquisa avaliou a resposta imune celular das vacas Holandesas em período de transição mediante resultados obtidos a partir do leucograma e análise de citometria de fluxo.

A avaliação dos leucócitos totais e células mononucleares a partir do leucograma permitiram evidenciar leucocitose por linfopenia. Kimura et al. (1999) também observaram pico máximo de leucócitos, porém não encontraram oscilações nos valores de células mononucleares obtidos por gradiente de densidade e citocentrifugação, e não apresentaram resultados diferenciais entre monócitos e linfócitos. 
Meglia et al. (2005) não apresentaram os valores do leucograma do pós-parto imediato, porém, de uma maneira geral os valores de leucócitos totais obtidos no período de transição foram inferiores aos observados nesta pesquisa, no entanto, as vacas desta pesquisa apresentaram o dobro de linfócitos e menores valores de monócitos.

Kim, Na e Yang (2005) avaliaram semanalmente as oscilações nos leucócitos totais e linfócitos da primeira semana pré-parto $(-1)$ à terceira semana pós-parto em vacas saudáveis e com metrite. Obtiveram para leucócitos totais $\left(x 10^{3} / \mathrm{HL}\right)$ equivalentes a 7,0 e 9,0 na semana -1; 9 e 11,0 no dia da parição; 6 e 8,0 na semana +1 e $+2 ; 6,5$ e 9,0 na semana +3 , respectivamente, no sangue das vacas saudáveis e com endometrite. Os valores de linfócitos obtidos entre as semanas -1 pré-parto a +3 pós-parto 3,2 e 4,1; 3,5 e 4,2; 3,0 e 4,1; 3,1 e 3,9; 3,2 e 4,1 ( $\left.\times 10^{3} / \mu \mathrm{L}\right)$, respectivamente, no sangue de animais saudáveis e com endometrite. Os valores observados pelos autores não apresentaram oscilações entre os momentos, mas sim entre o grupo de animais avaliados (saudáveis versus endometrite). Os valores de leucócitos totais e linfócitos observados pelos autores em todos os momentos avaliados se apresentaram abaixo dos observados nesta pesquisa.

Nagahata et al. (1992) analisaram o sangue de vacas Holandesas e observaram os seguintes valores de leucócitos totais: $6,9\left(\times 10^{3} / \mu \mathrm{L}\right)$ na segunda semana pré-parto; $8,4\left(\times 10^{3} / \mu \mathrm{L}\right)$ no momento da parição; $6,0\left(\times 10^{3} / \mu \mathrm{L}\right)$ no terceiro dia pós-parto; $5,7\left(\times 10^{3} / \mu \mathrm{L}\right)$ no sétimo dia pós-parto; e $5,9\left(\times 10^{3} / \mu \mathrm{L}\right)$ no $14^{\circ}$ dia pósparto, sendo possível observar aumento das células no momento da parição, concordando com os dados desta pesquisa. Os valores encontrados para linfócitos

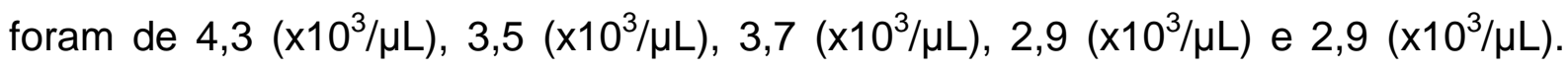
Nesta pesquisa, em alguns momentos os valores de linfócitos são aproximadamente o dobro dos valores observados pelos referidos autores.

A leucocitose por monocitose encontrada nesta pesquisa no momento da parição pode ser decorrente do estresse e liberação de cortisol. As concentrações de cortisol aumentam de 20 picogramas $/ \mathrm{mL}$ no início da gestação para picos de 4.000 a 6.000 picogramas $/ \mathrm{mL}$ nos momentos que antecedem o parto (CHEW et al., 1977).

O pico de leucócitos observado na parição é decorrente do aumento marcante no número de neutrófilos, pois o cortisol estimula a liberação de neutrófilos pela 
medula óssea do compartimento estoque para a circulação, além disso, este hormônio influencia na diminuição das moléculas de adesão expressas na superfície dos neutrófilos, o que leva a diminuição da ligação dessas células com as células endoteliais e migração tecidual. Outra hipótese seria a estimulação da granulopoiese na medula óssea (MADDUX; KEETON, 1987; BURTON et al., 1995; LA et al., 2001; WEBER et al., 2004). Dados relativos às células polimorfonucleares não estão apresentados nesta pesquisa.

A linfocitose observada nas vacas desta pesquisa em relação às pesquisas apresentadas por Meglia et al. (2005); Kim, Na e Yang (2005) e Nagahata et al. (1992) podem ser decorrentes da infecção causada pelo Vírus da Leucose Enzoótica Bovina (VLEB), pois 12/13 (92,3\%) eram soropositivas para esse agente viral. A linfocitose resultante da infecção pelo VLEB é classicamente aceita (Wood; Quiroz-Rocha, 2010).

Esta pesquisa não observou variações nas proporções e valores absolutos de linfócitos $\mathrm{T}\left(\mathrm{CD}^{+}\right)$no período de transição $(38,24$ a 42,39\%). A subpopulação de linfócitos $T(C D 8+)$ foi estável $(9,19$ a $11,55 \%)$, porém foi possível detectar oscilações no período de transição para os linfócitos $T$ auxiliares $\left(C D 4^{+}\right)$, observando diminuição acentuada dos valores relativos nas proximidades do parto (M-1 a M1).

As proporções de linfócitos $\mathrm{T}\left(\mathrm{CD}^{+}\right)$, especialmente a população de linfócitos auxiliares $\left(C D 4^{+}\right)$, foi inferior àquelas observadas por Kimura et al. (1999), que encontraram valores de $47,4 \%$ no d-30, atingindo o menor valor $(35,1 \%)$ no d1 após a parição, observando-se aumento gradual até atingir 49,8 no d10. A diminuição na população dos linfócitos $T$ próxima à parição foi decorrente da diminuição dos linfócitos auxiliares $\left(\mathrm{CD} 4^{+}\right)$e citotóxico $\left(\mathrm{CD} 8^{+}\right)$. Os resultados divergentes entre as pesquisas $\left(\mathrm{CD}^{+}\right)$podem ser decorrentes das diferentes raças (Holandesa versus Jersey), idade dos animais ( $<5$ anos versus $>5$ anos de idade). Trabalho de Ohtsuka et al. (2010) ressaltaram que vacas mais velhas apresentam menor proporção de células T CD8 ${ }^{+}$.

Apesar das oscilações semelhantes às relatadas na literatura para o linfócito T CD4 ${ }^{+}$, observou-se baixas proporções dessas células (4,79 a 11,73\%) em relação às proporções de 22,5-30,2\% e 27,5 $\pm 5,4$ relatadas por Kimura et al. (1999) e Meglia et al. (2005), respectivamente. 
Os linfócitos $B\left(\mathrm{CD} 21^{+}\right)$não apresentaram oscilações no período de transição, porém foi possível verificar pico dessas células no momento M2. As proporções de linfócitos B (45,69 a 60,86\%) estava acima de $40 \%$ encontrado para vacas sadias e semelhante à proporção de $58 \%$ encontrada em vacas soropositivas para o Vírus da Leucose Enzoótica Bovina por Lewin et al. (1988). Meglia et al. (2005) também encontraram menores proporções de células $B(19,6 \pm 6,9 \%)$ no período de transição.

As vacas desta pesquisa receberam a mesma dieta no período de estudo, porém as quantidades de cada componente foram ajustadas de acordo com o estado fisiológico e produtivo das vacas (gestação e lactação). A pesquisa foi realizada na Agência Paulista de Tecnologia dos Agronegócios (APTA) - unidade Gado de Leite, local que conta com a assessoria de zootecnistas, responsáveis pela formulação da dieta das vacas, que pode contribuído para a estabilização dos valores de $\mathrm{CD}^{+}$e $\mathrm{CD} 8^{+}$durante o período de estudo, além disso, a maioria das vacas manteve escore acima de 2,5 no pós-parto. Meglia et al. (2005) e Ohtsuka et al. (2006a) encontraram menor resposta imune celular em vacas que receberam ração com baixa energia.

No momento $\mathrm{M} 2$ desta pesquisa, observou-se menor valor de $\mathrm{CD}^{+}$e maior valor de linfócitos $B\left(C D 21^{+}\right)$, nesse período $4 / 13(31 \%)$ das vacas apresentavam endometrite. Pesquisa de Ohtsuka et al. (2004) demonstrou que vacas com processo inflamatório (mastite) no periparto apresentam menores proporções de $\mathrm{CD}^{+}, \mathrm{CD}^{+}$e $\mathrm{CD} 8^{+}$que animais hígidos.

As proporções das subpopulações de linfócitos $T$ não puderam ser correlacionadas aos indicadores energéticos, pois apresentaram ligeiras oscilações no período de estudo. 


\section{CONCLUSÕES}

Esta pesquisa avaliou o perfil metabólico e resposta imune celular no sangue de vacas Holandesas no período de transição. Com base nos resultados obtidos pode-se concluir que:

a) As vacas Holandesas apresentaram alterações nas variáveis do perfil energético, indicadores de balanço energético negativo e mobilização lipídica, caracterizadas especialmente pela diminuição do ECC e elevações nas concentrações séricas de NEFA e BHB;

b) Os teores de PT e GLOB apresentaram oscilações em decorrência da colostrogênese e infecções uterinas pós-parto. A albumina apresentou diminuição no pós-parto, decorrente do aumento da demanda nutricional para a produção de leite e uso de aminoácidos como precursor energético no processo de gliconeogênese;

c) Os valores de IGF-I apresentaram acentuada redução no momento do parto, sinalizando para mobilização lipídica e desacoplamento do eixo somatotrópico a partir da parição;

d) As vacas apresentaram hipocalcemia inaparente, especialmente na parição e primeira semana pós-parto;

e) A infecção pelo Vírus da Leucose Enzoótica Bovina influenciou na resposta imune observada no período de transição, caracterizada por linfocitose e aumento da população de linfócitos $B\left(C D 21^{+}\right)$. 


\section{REFERÊNCIAS}

ACCORSI, P. A.; GOVONI, N.; GAIANI, R.; PEZZI, C.; SEREN, E.; TAMANINI, C. Leptin, $\mathrm{GH}, \mathrm{PRL}$, insulin and metabolic parameters throughout the dry period and lactation in dairy cows. Reproduction in Domestic Animals, v. 40, n. 3, p. 217-223, 2005.

ARAÚJO, C. A. S. C. Estudo comparativo do perfil metabólico e hormonal de ovelhas com gestação única, gemelar e não gestantes alimentadas com dieta de alta densidade energética, 2009. 212 f. Dissertação (Mestrado em Medicina Veterinária) - Faculdade de Medicina Veterinária e Zootecnia, Universidade de São Paulo, São Paulo, 2009.

BACILLI, C. C. Imunização passiva e ativa de bezerros para o Vírus da Diarréia Viral Bovina (BVDV) e Herpesvírus Bovino tipo 1 (BoHV-1), 2013, $124 \mathrm{f}$. Dissertação (Mestrado em Medicina Veterinária) - Faculdade de Medicina Veterinária e Zootecnia, Universidade de São Paulo, São Paulo, 2013.

BARRETO JUNIOR, R. A. Estudo de um modelo experimental de indução e tratamento de hipocalcemia em bovinos e esquinos, 2007. 95 f. Tese (Mestrado em Medicina Veterinária) - Faculdade de Medicina Veterinária e Zootecnia, Universidade de São Paulo, São Paulo, 2007.

BARRINGTON, G. M.; MCFADDEN, T. B.; HUYLER, M. T.; BESSER, T. E. Regulation of colostrogenesis in cattle. Livestock Production Science, v. 70, n. 1-2, p. 95-104, 2001.

BAUMAN, D. E.; BRUCE CURRIE, W. Partitioning of nutrients during pregnancy and lactation: a review of mechanisms involving homeostasis and homeorhesis. Journal of Dairy Science, v. 63, n. 9, p. 1514-1529, 1980.

BEITZ, D. C. Digestão, absorção e metabolismo. In: Dukes fisiologia dos animais domésticos. 11. ed. Rio de Janeiro: Guanabara-Koogan, 1996.

BELL, A. W. Regulation of organic nutrient metabolism during transition from late pregnancy to early lactation. Journal of Animal Science, v. 73, p. 2804-2819, 1995.

BELL, A. W.; BAUMAN, D. E. Adaptations of glucose metabolism during pregnancy and lactation. Journal of Mammary Gland Biology and Neoplasia, v. 2, n. 3, p. 265-78, 1997.

BELL, A. W.; BURHANS, W. S.; OVERTON, T. R. Protein nutrition in late pregnancy, maternal protein reserves and lactation performance in dairy cows. The

Proceedings of the Nutrition Society, v. 59, p. 119-126, 2000.

BIRGEL. E. H.; BENESEI, F. J. Hematologia clínica veterinária. São Paulo: Sociedade Paulista de Medicina Veterinária, 1982. 
BIRGEL JUNIOR, E. H.; NEVES, F. S.; SALVATORE, L. C. A.; MIRANDOLA, R. M. S.; TÁVORA, J. P. F.; BIRGEL, E. H. Avaliação da influência da gestação e do puerpério sobre a função hepática de bovinos da raça holandesa. Ars Veterinaria, v. 19, n. 2, p. 172-178, 2003.

BRUSS, M. L. Lipids and ketones. In: KANEKO, J. J.; HARVEY, J. W.; BRUSS, M. L. Clinical Bichemistry of Domestic Animals. 6 ed. San Diego: Academic Press, 2008.

BURTON, J. L.; KEHRLI JR.; M. E.; KAPIL S.; HORST R. L. Regulation of L-selectin and CD18 on bovine neutrophils by glucocorticoids: effects of cortisol and dexamethasone. Journal of Leukocyte Biology, v. 57, p. 317-325, 1995.

BUSATO, A.; FAISSLE, D.; KÜPFER, U.; BLUM, J. W. Body condition scores in dairy cows: associations with metabolic and endocrine changes in healthy dairy cows.

Journal of Veterinary Medicine Série A, v. 49, n. 9, p. 455-60, 2002.

BUTLER, J.E. Bovine immunoglobulins: an augmented review. Veterinary Immunology and Immunopathology, v. 4, p. 43, 1983.

CHAPINAL, N.; CARSON, M.; DUFFIELD, T. F.; CAPEL, M.; GODDEN, S.; OVERTON, M.; SANTOS, J. E. P. LEBLANC, S. J. The association of serum metabolites with clinical disease during the transition period. Journal of Dairy Science, v. 94, n. 10, p. 4897-4903, 2011.

CHAPINAL, N.; CARSON, M. E.; LEBLANC, S. J.; LESLIE, K. E.; GODDEN, S.; CAPEL, M.; SANTOS, J. E. P.; OVERTON, M. W.; DUFFIELD, T. F. The association of serum metabolites in the transition period with milk production and early-lactation reproductive performance. Journal of Dairy Science, v. 95, n. 3, p. 1301-1309, 2012a.

CHAPINAL, N.; LEBLANC, S. J.; CARSON, M. E.; LESLIE, K. E.; GODDEN, S.; CAPEL, M.; SANTOS, J. E. P.; OVERTON, M. W.; DUFFIELD, T. F. Herd-level association of serum metabolites in the transition period with disease, milk production, and early lactation reproductive performance. Journal of Dairy Science, v. 95, n. 10 , p. 5676-5682, 2012 b.

CHEW, B. P.; KELLER, H. F.; ERB, R. E.; MALVEN, P. V. Periparturient concentrations of prolactin , progesterone and the estrogens in blood plasma of cows retaining and not retaining fetal. Journal of Animal Science, v. 44, p. 1055-1060, 1977.

CINCOVIC, R. M.; BRANISLAVA, B.; BILJANA, R.; HRISTOV, S.; DKOVIC, R. Influence of lipolysis and ketogenesis to metabolic and hematological parameters in dairy cows during periparturient period. Acta Veterinaria (Beograd), v. 62, n. 4, p. 429-444, 2012. 
CORASSIN, C. H. Determinação e avaliação de fatores que afetam a produtividade de vacas leiteiras: aspectos sanitários e reprodutivos, 2004. Tese (Doutorado em Agronomia) - Escola Superior de Agricultura Luiz de Queiroz, Universidade de São Paulo, Piracicaba, 2004.

CORREA, M. N.; GONZÁLEZ, F. H. D.; SILVA, S. C. Transtornos relacionados ao metabolismo de minerais. In: Transtornos metabólicos nos animais domésticos. Pelotas: Ed. Universitária PREC/UFPEL, 2010.

CURTIS, C. R.; ERB, H. N.; SMIFFEN, G. J.; SMITH, R. D.; POWERS, P. A.; SMITH, M. C.; WHITE, M. E.; HILLMAN, R. B.; PEARSON, E. J. Association of parturient hypocalcemia with periparturient disorders in Holstein cows. Journal of the American Veterinery Medicine Association, v. 183, n. 5, p. 559-561, 1983.

DAVIS, A. K.; MANEY, D. L.; MAERZ, J. C. The use of leukocyte profiles to measure stress in vertebrates: a review for ecologists. Functional Ecology, v. 22, n. 5, p. 760-772, 2008.

DETILLEUX, J. C.; KEHRLI, M. E.; STABEL, J. R.; FREEMAN, A E.; KELLEY, D. H. Study of immunological dysfunction in periparturient Holstein cattle selected for high and average milk production. Veterinary Immunology and Immunopathology, v. 44, n. 3-4, p. 251-67, 1995.

DRACKLEY, J. K. Biology of dairy cows during the transition period: the final frontier? Journal of Dairy Science, v. 82, n. 11, p. 2259-2273, 1999.

DRACKLEY, J. K.; OVERTON, T. R.; DOUGLAS, G. N. Adaptations of glucose and long-chain fatty acid metabolism in liver of dairy cows during the periparturient period. Journal of Dairy Science, v. 84, p. E100-E112, 2001.

DUFFIELD, T. F.; LISSEMORE, K. D.; MCBRIDE, B. W.; LESLIE, K. E. Impact of hyperketonemia in early lactation dairy cows on health and production. Journal of Dairy Science, v. 92, n. 2, p. 571-580, 2009.

EDMONSON, A. J.; LEAN, I. J.; WEAVER, L. D.; FARVER, T.; WEBSTER, G. A Body condition scoring chart for holstein dairy cows. Journal of Dairy Science, v. 72, n. 1, p. 68-78, 1989.

FAGLIARI, J.; SANTANA, A. E.; LUCAS, F. A.; CAMPOS FILHO, E.; CURI, P. Constituintes sangüíneos de bovinos lactantes, desmamados e adultos das raças Nelore (Bos indicus) e Holandesa (Bos Taurus) e de bubalinos (Bubalus bubalis) da raça Murrah. Arquivo Brasileiro de Medicina Veterinária e Zootecnia, v. 50, n. 3, p. 263-271, 1998.

GOFF, J. P. Pathophysiology of calcium and phosphorus disorders. Veterinary Clinics of North America: Food Animal Practice, v. 16, n. 2, p. 319-339, 2000. 
GOFF, J. P. Macromineral disorders of the transition cow. The Veterinary Clinics of North America: Food Animal Practice, v. 20, n. 3, p. 471-494, 2004.

GOFF, J. P. The monitoring, prevention, and treatment of milk fever and subclinical hypocalcemia in dairy cows. The Veterinary Journal, v. 176, p. 50-57, 2008.

GOFF, J. P.; KEHRLI, M. E.; HORST, R. L. Periparturient hypocalcemia in cows: prevention using intramuscular parathyroid hormone. Journal of Dairy Science, v. 72, n. 5, p. 1182-1187, 1989.

GOFF, W.; JOHNSON, W. ; PARISH, S.; BARRINGTON, G. M.; ELSASSER, T. H.; DAVIS, W.C.; VALDEZ, R.A. IL-4 and IL-10 inhibition of IFN- $\gamma$ - and TNF- $\alpha$-dependent nitric oxide production from bovine mononuclear phagocytes exposed to Babesia bovis merozoites. Veterinary Immunology and Immunopathology, v. 84, n. 3-4, p. 237-251, 2002.

GONZÁLEZ, F. H. D.; SILVA, S. C. Introdução à bioquímica clínica veterinária. Porto Alegre: UFRGS, 2006.

GORDON, J. L.; LeBLANC, S. J.; DUFFIELD, T.F. Ketosis treatment in lactating Dairy Cattle. Veterinary Clinics of North America: Food Animal Pratice, v. 29, n2, p. 433-445, 2013.

GRACE, N. D. Phosphorus kinetics in sheep. British Journal of Nutrition, v. 45, n. 2, p. 367-374, 1981.

GRANT, A. B. Carotene: a rachitogenic factor in green feeds. Nature, v. 172, p. 627 , 1953.

GRUMMER, R. R. Impact of changes in organic nutrient metabolism on feeding the transition dairy cow. Journal of Animal Science, v. 73, p. 2820-2833, 1995.

GUYTON, A. C. Fisiologia humana. 6. ed. Rio de Janeiro: Guanabara Koogan, 2008.

HAMMOM, D. S.; EVJEN, I. M.; DHIMAN, T. R.; GOFF, J. P.; WALTERS, J. L. Neutrophil function and energy status in Holstein cows with uterine health disorders. Veterinary Immunology and Immunopathology, v. 113, p. 21-29, 2006.

HAMMON, H. M.; STÜRMER, G.; SCHNEIDER, F.; TUCHSCHERER, A.; BLUM, H.; ENGELHARD, T.; GENZEL, A.; STAUFENBIEL, R.; KANITZ, W. Performance and metabolic and endocrine changes with emphasis on glucose metabolism in highyielding dairy cows with high and low fat content in liver after calving. Journal of Dairy Science, v. 92, n. 4, p. 1554-1566, 2009.

HAYIRLI, A; GRUMMER, R. R.; NORDHEIM, E. V; CRUMP, P. M. Animal and dietary factors affecting feed intake during the prefresh transition period in Holsteins. Journal of Dairy Science, v. 85, n. 12, p. 3430-3443, 2002. 
HERDT, T. H. Ruminant adaptation to negative energy balance, Veterinary Clinics of North America: Food Animal Practice, v. 16, n. 2, p. 215-230, 2000.

HIBBS, J. W.; CONRAD, H. R. The relation of calcium and phosphorus intake and digestion and the effects of vitamin $D$ feeding on the utilization of calcium and phosphorus by lactating dairy cows. Ohio Agricultural Research and Development Center, Bulletin, 1983, p. 1150.

HORST, R. L. Regulation of calcium and phosphorus homeostasis in the dairy cow. Journal of Dairy Science, v. 69, n. 2, p. 604-616, 1986.

HORST, R. L.; GOFF, J. P.; REINHARDT, T. A. Calcium and vitamin D metabolism in the dairy cow. Journal of Dairy Science, v. 77, n. 7, p. 1936-1951, 1994.

INGVARTSEN, K. L.; DEWHURST, R. J.; FRIGGENS, N. C. On the relationship between lactational performance and health: is it yield or metabolic imbalance that cause production diseases in dairy cattle? A position paper. Livestock Production Science, v. 83, p. 277-308, 2003.

INGVARTSEN, K. L.; MOYES, K. Nutrition, immune function and health of dairy cattle. Animal, v. 7, n. Suplemento 1, p. 112-122, 2013.

IRELAND, M. J. C.; LACEY, B.; MALLARD, B. A. Insulin-like growth factor-I and growth hormone: possible immunomodulatory effects on CD markers in the periparturient Holstein. p. 323. In: INTERNATIONAL VETERINARY SYMPOSIUM, 4., 1995, Davis, Abstract...[S.I], 1995

JACKSON, P. G. G. Nascimento normal. In: Obstetrícia veterinária. 2. ed. São Paulo: Roca, 2006.

KANEKO, J. J.; HARVEY, J. W.; BRUSS, M. L. Appendix VIII blood analyte reference values in large animals. In: KANEKO, J. J.; HARVEY, J. W.; BRUSS, M. L. Clinical Bichemistry of Domestic Animals. 6. ed. San Diego: Academic Press, 2008.

KEMLER, R. H.; MOSSMANN, H.; STROHMAIER, B.; KICKHOFEN, B.; HAMMER, D.K. In vitro studies on the selective binding of IgG from different species to tissue sections of the bovine mammary gland. European Journal of Immunology, v. 5, p. 603, 1975.

KEY, L. Y.; CARNES, D.; COLE, S.; HOLTROP, M.; BAR-SAVIT, Z.; SHAPIRO, F.; ARCECI, R.; STEINBERG, J.; GUNDBERG, C.; KAHN, A.; TEITELBAUM, S.; ANAST, C. Treatment of congenital osteopetrosis with high-dose calcitriol. New England Journal of Medicine, v. 310, p. 409, 1984.

KIM, I. H.; NA, K. J.; YANG, M. P. Immune responses during the peripartum period in dairy cows with postpartum endometritis. The Journal of Reproduction and Development, v. 51, n. 6, p. 757-64, 2005. 
KIMURA, K.; GOFF, J. P.; KEHRLI, M. E.; HARP, J. A. Phenotype analysis of peripheral blood mononuclear cells in periparturient dairy cows. Journal of Dairy Science, v. 82, n. 2, p. 315-319, 1999.

KIMURA, K.; GOFF, J. P.; KEHRLI, M. E.; HARP, J. A; NONNECKE, B. J. Effects of mastectomy on composition of peripheral blood mononuclear cell populations in periparturient dairy cows. Journal of Dairy Science, v. 85, n. 6, p. 1437-1444, 2002.

KIMURA, K.; REINHARDT, T. A; GOFF, J. P. Parturition and hypocalcemia blunts calcium signals in immune cells of dairy cattle. Journal of Dairy Science, v. 89, n. 7, p. 2588-2595, 2006.

KIROVSKI, D.; LAZAREVIC, M.; STOJIC, V.; SAMANC, H.; VUJANAC, I.; NEDIC, O. MASNIKOSA, R. Hormonal status and regulation of glycemia in neonatal calves during the first hours of postnatal life. Acta Veterinaria, v. 61, n. 4, p. 349-361, 2011.

LA, M.; TAILOR, A.; D'AMICO, M.; FLOWER, R. J.; PERRETTI, M. Analysis of the protection afforded by annexin 1 in ischaemia-reperfusion injury: focus on neutrophil recruitment. European Journal of Pharmacology, v. 429, p. 263-278, 2001.

LAEGER, T.; WIRTHGEN, E.; PIECHOTTA, M.; METZGER, F.; METGES, C. C. KUHLA, B.; HOEFLICH, A. Effects of parturition and feed restriction on concentrations and distribution of the insulin-like growth factor-binding proteins in plasma and cerebrospinal fluid of dairy cows. Journal of Dairy Science, v. 97, n. 5, p. 2876-2885, 2014.

LAGO, E. P.; PIRES, A. V.; SUSIN, I.; FARIA, V. P.; LAGO, L. A. Efeito da condição corporal ao parto sobre alguns parâmetros do metabolismo energético, produção de leite e incidência de doenças no pós-parto de vacas leiteiras. Revista Brasileira de Zootecnia, v. 30, n. 5, p. 1544-1549, 2001.

LANG, C. H.; FROST, R. A. Role of growth hormone, insulin-like growth factor-I, and insulin-like growth factor binding proteins in the catabolic response to injury and infection. Current Opinion in Clinical Nutrition and Metabolic Care, v. 5, n. 3, p. 271-279, 2002.

LARSON, B. L. Biosynthesis and cellular secretion of milk. In: Lactation. Ames: lowa State University Press, 1985.

LARSON, B. L. Immunoglobulins of the mammary secretions. In: FOX, P.F. Advanced dairy chemistry. Proteins. London: Elsevier, 1992. v. 1, p. 231.

LEBLANC, S. Monitoring metabolic health of dairy cattle in the transition period. The Journal of Reproduction and Development, v. 56, p. S29-S35, 2010. Suplemento 1

LEBLANC, S. J.; LESLIE, K. E.; DUFFIELD, T. F. Metabolic predictors of displaced abomasum in dairy cattle. Journal of Dairy Science, v. 88, n. 1, p. 159-170, 2005. 
LEWIN, H. A; WU, M. C.; NOLAN, T. J.; STEWART, J. A. Peripheral B lymphocyte percentage as an indicator of subclinical progression of bovine leukemia virus infection. Journal of Dairy Science, v. 71, n. 9, p. 2526-2534, 1988.

LOISELLE, M. C.; STER, C.; TALBOT, B. G.; ZHAO, X.; WAGNER, G. F.; BOISCLAIR, Y. R. LACASSE, P. Impact of postpartum milking frequency on the immune system and the blood metabolite concentration of dairy cows. Journal of Dairy Science, v. 92, n. 5, p. 1900-1912, 2009.

MADDUX, J. M.; KEETON, K. S. Effects of dexamethasone, levamisole, and dexamethasone-levamisole combination on neutrophil function in female goats. American Journal of Veterinary Research, v. 48, n. 7, p. 1114-1119, 1987.

MALLARD, B. A.; DEKKERS, J. C.; IRELAND, M. J.; LESLIE, K. E.; SHARIF, S.; LACEY VANKAMPEN, C.; WAGTER, L.; WILKIE, B. N. Alteration in immune responsiveness during the peripartum period and its ramification on dairy cow and calf health. Journal of Dairy Science, v. 81, p. 585-595, 1998.

MALLARD, B. A.; WAGTER, L. C.; IRELAND, M. J.; DEKKERS, J. C. Effects of growth hormone, insulin-like growth factor-I, and cortisol on periparturient antibody response profiles of dairy cattle. Veterinary Immunology and Immunopathology, v. 60, p. 61-76, 1997.

MASSEY, C. D., WANG, C.; DONOVAN, G. A.; BEEDE, D. K. Hypocalcemia as a risk factor for left displacement of the abomasum in dairy cows. Journal of the American Veterinary Medecal Assocociation, v. 203, p. 852-853, 1993

MCART, J. A. A.; NYDAM, D. V; OETZEL, G. R.; OVERTON, T. R.; OSPINA, P. A. Elevated non-esterified fatty acids and $\beta$-hydroxybutyrate and their association with transition dairy cow performance. The Veterinary Journal, v. 198, p. 560-570, 2013.

MEGLIA, G. E.; JOHANNISSON, A.; AGENÄS, S.; HOLTENIUS, K.; WALLER, K. P. Effects of feeding intensity during the dry period on leukocyte and lymphocyte subpopulations, neutrophil function and health in periparturient dairy cows. The Veterinary Journal, v. 169, p. 376-384, 2005.

MOREIRA, T. F. Perfil metabólico de vacas leiteiras no período de transição em sistema semi-intensivo em Minas Gerais no verão e no inverno, 2013. 123 f.

Dissertação (Mestrado em Medicina Veterinária) - Escola de Veterinária, Universidade Federal de Minas Gerais, Belo Horizonte, 2013.

MOUFFOK, C. E.; MADANI, T.; SEMANA, L.; AYACHE, N.; RAHAL, A. Correlation between body condition score, blood biochemical metabolites, milk yield and quality in Algerian Montbéliarde cattle. Pakistan Veterinary Journal, v. 33, n. 2, p. 191194, 2013.

MULLIGAN, F. J.; DOHERTY, M. L. Production diseases of the transition cow. Veterinary Journal, v. 176, p. 3-9, 2008. 
NAGAHATA, H.; OGAWA, A; SANADA, Y.; NODA, H.; YAMAMOTO, S. Peripartum changes in antibody producing capability of lymphocytes from dairy cows. The Veterinary Quarterly, v. 14, n. 1, p. 39-40, 1992.

NOWAK, W.; MIKUŁA, R.; PRUSZYŃSKA-OSZMAŁEK, E.; STEFAŃSKA, B.; MAĆKOWIAK, P.; KASPROWICZ-POTOCKA, M.; FRANKIEWICZ, A. Effect of restricted feeding in the far-off period on performance and metabolic status of dairy cows. Annals of Animal Science, v. 14, n. 1, p. 89-100, 2014.

OHTSUKA, H.; KOHIRUIMAKI, M.; HAYASHI, T.; KATSUDA, K.; MATSUDA, K.; MASUI, M.; ABE, R.; KAWAMURA, S. Relationship between leukocyte population and nutritive conditions in dairy herds with frequently appearing mastitis. The Journal of Veterinary Medical Science, v. 68, n. 2, p. 113-8, 2006b.

OHTSUKA, H.; KOIWA, M.; FUKUDA, S.; SATOH, Y.; HAYASHI, T.; HOSHI, F.; YOSHINO, T.; KAWAMURA, S. Changes in peripheral leukocyte subsets in dairy cows with inflammatory diseases after calving. The Journal of Veterinary Medical Science, v. 66, n. 8, p. 905-999, 2004.

OHTSUKA, H.; TERASAWA, S.; WATANABE, C.; KOHIRUIMAKI, M.; MUKAI, M.; ANDO, T.; PETROVSKI, K.; MORRIS, S. Effect of parity on lymphocytes in peripheral blood and colostrum of healthy Holstein dairy cows. The Canadian Journal of Veterinary Research, v. 74, p. 130-135, 2010.

OHTSUKA, H.; WATANABE, C.; KOHIRUIMAKI, M.; ANDO, T.; WATANABE, D.; MASUI, M.; HAYASHI, T.; ABE, R.; KOIWA, M.; SATO, S. KAWAMURA, S. Comparison of two different nutritive conditions against the changes in peripheral blood mononuclear cells of periparturient dairy cows. The Journal of Veterinary Medical Science, v. 68, n. 11, p. 1161-1166, 2006a.

ORTOLANI, E. L. Aspectos clínicos, epidemiológicos e terapêuticos da hipocalcemia de vacas leiteiras. Arquivo Brasileiro de Medicina Veterinária e Zootecnia, v. 47, n. 6, p. 799-808, 1995.

PARTISETI, M.; LE DEIST, F.; HIVROZ, C.; FISCHER, A.; KORN, H.; CHOQUET, D. The calcium current activated by $T$ cell receptor and store depletion in human lymphocytes is absent in a primary immunodeficiency. The Journal of Biological Chemistry, v. 269, n. 51, p. 32327-32335, 1994.

PATEL, O. V; TAKAHASHIT, T.; TAKENOUCHI, N.; HIRAKO, M.;SASAKI, N.; DOMEKI, L. Peripheral cortisol levels throughout gestation in the cow : effect of stage of gestation and foetal number. British Veterinary Journal, v. 152, p. 425-432, 1996.

RAMBERG, C. F.; JOHNSON, E. K.; FARGO, R. D.; KRONFELD, D. S. Calcium homeostasis in cows with special reference to parturient hypocalcemia. American Journal of Physiology, v. 246, p. R698-R704, 1984. 
RAMBERG, C. F.; KRONFELD D. S.; WILSON, G. D. A. Regulation of calcium metabolism in cattle during growth, lactation, and change in diet. In: MC DINALD, I. W.; WARNER, A. C. I. Digestion and metabolism in the ruminant. Amidale: University of New England Publishing Unit, 1975.

REINHARDT, T. A.; LIPPOLIS, J. D.; MCCLUSKEY, B. J.; GOFF, J. P.; HORST, R. $\mathrm{L}$. Prevalence of subclinical hypocalcemia in dairy herds. The Veterinary Journal, v. 188, n. 1, p. 122-4, 2011.

REYNOLDS, C. K.; HUNTINGTON, G. B.; TYRRELL, H. F.; REYNOLDS, P. J. Net portal-drained visceral and hepatic metabolism of glucose, L-lactate, and nitrogenous compounds in lactating holstein cows. Journal of Dairy Science, v. 71, n. 7, p. 1803-1812, 1988.

RONGE, H.; BLUM, J.; CLEMENT, C.; JANS, F.; LEUENBERGER, H.; BINDER, H. Somatomedin $\mathrm{C}$ in dairy cows related to energy and protein supply and to milk production. Animal Production, v. 47, n. 2, p. 165-183, 1988.

ROSENBERGER, G. Exame clínico dos bovinos. 3. ed. Rio de Janeiro: Guanabara, Koogan, 2008.

SAMANC, H.; KIROVSKI, D.; STOJIC, V.; et al. Application of the metabolic profile test in the prediction and diagnosis of fatty liver in Holstein cows. Acta veterinaria, v. 5, n. 6, p. 543-553, 2011.

SEAL, C. J.; REYNOLDS, C. K. Nutritional implications of gastrointestinal and liver. Nutrition Research Reviews, v. 6, p. 185-208, 1993.

SIMMONS, C. R.; BERGEN, W. G.; VANDEHAAR, M. J.; SPRECHER, D. J.; SNIFFEN, C. J.; STANISIEWSKI, E. P.; TUCKER, H. A. Protein and fat metabolism in cows given somavubove before parturition. Journal of Dairy Science, v. 77, n. 7, p. 1835-1847, 1994.

SORDILLO, L. M.; NICKERSON, S. C.; AKERS, R. M.; OLIVER, S. P. Secretion composition during bovine mammary involution and the relationship with mastitis. The International Journal of Biochemistry, v. 19, n. 12, p. 1165-1172, 1987.

SOUZA, R. M. DE; BIRGEL JUNIOR, E. H. Influência do puerpério e da fase póspuerperal no lipidograma de vacas da raça Holandesa criadas no Estado de São Paulo. Brazilian Journal of Veterinary Research and Animal Science, v. 46, n. 1, p. 5-10, 2009.

STER, C.; LOISELLE, M.; LACASSE, P. Effect of postcalving serum nonesterified fatty acids concentration on the functionality of bovine immune cells. Journal of Dairy Science, v. 95, n. 2, p. 708-717, 2012.

TAYLOR, V. J.; CHENG, Z.; PUSHPAKUMARA, P. G. A.; BEEVER, D. E.; WATHES, D. C. Relationships between the plasma concentrations of insulin-like growth factor-I in dairy cows and their fertility and milk yield. Vetrinary Record, v. 155, p. 583-588, 2004. 
VAGNONI, D. B.; OETZEL, G. R. Effects of dietary cation-anion difference on the acid-base status of dry cows. Journal of Dairy Science, v. 81, p. 1643- 1652, 1998.

VAN KAMPEN, C.; MALLARD, B. A. Effects of peripartum stress and health on circulating bovine lymphocyte subsets. Veterinary Immunology and Immunopathology, v. 59, p. 79-91, 1997.

WATHES, D. C.; CHENG, Z.; CHOWDHURY, W.; FENWICK, M.; FITZPATRICK, R.; MORRIS, D.; PATTON, J.; MURPHY, J. Negative energy balance alters global gene expression and immune responses in the uterus of postpartum dairy cows.

Physiological Genomics, v. 39, p. 1-13, 2009.

WEBER, P. S. D.; TOELBOELL, T.; CHANG, L.; TIRRELL, J. D.; SAAMA, P. M.; SMITH, G. W.; BURTON, J. L. Mechanisms of glucocorticoid-induced downregulation of neutrophil L-selectin in cattle: evidence for effects at the geneexpression level and primarily on blood neutrophils. Journal of Leukocyte Biology, v. 75, p. 815-827, 2004.

WOOD, D.; QUIROZ-ROCHA, G. F. Normal hematology of cattle. In: WEISS, D. J.; WARDROP, K. J. Schalm's Veterinary Hematology. 6 ed. Malden: Wiley Blackwell, 2010. 
Apêndice 


\section{APÊNDICE A}

Tabela 14 - Significâncias obtidas na comparação dos ECC das vacas Holandesas entre os momentos de estudo - São Paulo 2013

\begin{tabular}{lccccc}
\hline ECC & M-1 & M0 & M1 & M2 & M3 \\
\hline M-2 & 0,157 & 0,008 & 0,004 & 0,014 & 0,107 \\
M-1 & & 0,005 & $0,003^{*}$ & 0,007 & 0,132 \\
M0 & & & 0,023 & 0,317 & 0,705 \\
M1 & & & & 0,058 & 0,009 \\
M2 & & & & & 0,025 \\
\hline
\end{tabular}

Legenda: * Diferença significativa com a correção de Bonferroni $(p \leq 0,003)$; ECC - Escore de Condição Corporal; M-2: $2^{\circ}$ semana préparto; $\mathrm{M}-1$ : $1^{\circ}$ semana pré-parto; $\mathrm{M} 0$ : dia do parto; $\mathrm{M} 1 ; 1^{\circ}$ semana pós-parto; M2: $2^{\circ}$ semana pós-parto; M3: $3^{\circ}$ semana pós-parto. 
Tabela 15 - Significâncias obtidas na comparação dos marcadores do perfil energético das vacas Holandesas entre os momentos de estudo São Paulo - 2013

Comparação entre os momentos

\begin{tabular}{|c|c|c|c|c|c|c|c|c|c|c|c|c|c|c|c|}
\hline \multirow{2}{*}{ Momentos } & \multicolumn{5}{|c|}{ Glicose } & \multicolumn{5}{|c|}{ NEFA } & \multicolumn{5}{|c|}{ BHB } \\
\hline & $M-1$ & M0 & M1 & M2 & M3 & $M-1$ & M0 & M1 & M2 & M3 & $M-1$ & M0 & M1 & M2 & M3 \\
\hline M-2 & 0,477 & 0,019 & 0,328 & 0,075 & 0,047 & 0,036 & $0,003^{*}$ & $0,003^{*}$ & $0,003^{*}$ & $0,002^{*}$ & 0,753 & 0,091 & 0,01 & 0,308 & 0,158 \\
\hline M-1 & & 0,091 & 0,075 & 0,015 & 0,008 & & 0,004 & $0,003^{*}$ & 0,071 & 0,272 & & 0,013 & 0,016 & 0,388 & 0,136 \\
\hline M0 & & & 0,013 & $0,003^{*}$ & 0,01 & & & 0,657 & $0,003^{*}$ & $0,002^{*}$ & & & 0,182 & 0,814 & 0,084 \\
\hline M1 & & & & 0,23 & 0,155 & & & & 0,005 & $0,003^{*}$ & & & & 0,346 & 0,06 \\
\hline M2 & & & & & 0,722 & & & & & 0,055 & & & & & 0,152 \\
\hline \multirow{2}{*}{ Momento } & \multicolumn{5}{|c|}{ Triglicérides } & \multicolumn{5}{|c|}{ Colesterol } & \multicolumn{5}{|c|}{ IGF-I } \\
\hline & M-1 & M0 & M1 & M2 & M3 & M-1 & M0 & M1 & M2 & M3 & $\mathrm{M}-1$ & M0 & M1 & M2 & M3 \\
\hline$M-2$ & 0,028 & 0,05 & 0,021 & 0,005 & 0,012 & 0,600 & 0,477 & 0,625 & 0,456 & 0,004 & 0,929 & 0,017 & $0,003^{*}$ & 0,004 & 0,006 \\
\hline$M-1$ & & $0,003^{*}$ & $0,003^{*}$ & $0,002^{*}$ & $0,002^{*}$ & & $0,003^{*}$ & 0,016 & 1,000 & $0,003^{*}$ & & 0,01 & $0,003^{*}$ & $0,003^{*}$ & $0,003^{*}$ \\
\hline MO & & & 0,423 & 0,084 & 0,754 & & & 0,398 & 0,041 & $0,002^{*}$ & & & 0,674 & 1 & 0,445 \\
\hline M1 & & & & 0,367 & 0,724 & & & & 0,019 & $0,002^{*}$ & & & & 0,31 & 0,041 \\
\hline M2 & & & & & 0,173 & & & & & $0,002^{*}$ & & & & & 0,093 \\
\hline
\end{tabular}

Legenda: * Diferenças significativas ( $\leq 0,003)$; NEFA - Ácidos Graxos Não Esterificados; BHB - Beta-hidroxibutirato; IGF-I - Fator de Crescimento Semelhante à Insulina; M-2: $2^{\circ}$ semana pré-parto; M-1: $1^{\circ}$ semana pré-parto; M0: dia do parto; M1; $1^{\circ}$ semana pósparto; M2: $2^{\circ}$ semana pós-parto; M3: $3^{\circ}$ semana pós-parto. 
Tabela 16 - Significâncias obtidas na comparação dos marcadores do perfil proteico das vacas Holandesas entre os momentos de estudo - São Paulo - 2013

\begin{tabular}{|c|c|c|c|c|c|}
\hline \multicolumn{6}{|c|}{ Wilcoxon } \\
\hline Proteína Total (g/dl) & $\mathrm{M}-1$ & MO & M1 & M2 & M3 \\
\hline M-2 & 0,347 & 0,248 & 0,79 & 0,239 & $0,003^{*}$ \\
\hline$M-1$ & & 0,286 & 0,477 & 0,784 & $0,002^{*}$ \\
\hline MO & & & 0,79 & 0,53 & $0,002^{*}$ \\
\hline M1 & & & & 0,071 & $0,003^{*}$ \\
\hline M2 & & & & & $0,002^{*}$ \\
\hline Albumina (g/dl) & $\mathrm{M}-1$ & MO & M1 & M2 & M3 \\
\hline M-2 & 0,109 & 0,091 & 0,859 & 0,197 & 0,44 \\
\hline$M-1$ & & 0,66 & 0,008 & 0,004 & 0,018 \\
\hline M0 & & & 0,005 & 0,005 & 0,007 \\
\hline M1 & & & & 0,645 & 0,443 \\
\hline $\mathrm{M} 2$ & & & & & 0,097 \\
\hline Globulina $(\mathrm{g} / \mathrm{dl})$ & $\mathrm{M}-1$ & Mo & M1 & $\mathrm{M} 2$ & M3 \\
\hline M-2 & 0,308 & 0,477 & 0,091 & 0,008 & $0,003^{*}$ \\
\hline $\begin{array}{l}\text { M-1 } \\
\text { M0 }\end{array}$ & & 0,11 & $\begin{array}{l}0,328 \\
0,155\end{array}$ & $\begin{array}{c}0,041 \\
0,05\end{array}$ & $\begin{array}{l}0,003^{*} \\
0,002^{*}\end{array}$ \\
\hline M1 & & & & 0,034 & 0,004 \\
\hline $\mathrm{M} 2$ & & & & & $0,003^{*}$ \\
\hline ALB/GLOB (g/dl) & $\mathrm{M}-1$ & MO & M1 & $\mathrm{M} 2$ & M3 \\
\hline$M-2$ & 0,763 & 0,314 & 0,012 & $0,002^{*}$ & $0,003^{*}$ \\
\hline$M-1$ & & 0,493 & 0,014 & $0,003^{*}$ & 0,005 \\
\hline MO & & & 0,005 & $0,002^{*}$ & $0,002^{*}$ \\
\hline M1 & & & & 0,007 & 0,004 \\
\hline M2 & & & & & 0,015 \\
\hline $\begin{array}{r}\text { Legenda: * } \text { Diferença } \\
\text { Globulina; } \\
\text { parto; M0 } \\
\text { semana }\end{array}$ & IV de & $=0,0$ & ALB & $\begin{array}{l}\text { Albur } \\
\text { 1: } 1^{\circ}\end{array}$ & $\begin{array}{l}\text { GLOB - } \\
\text { ana pré- } \\
\text {; M2: } 2^{\circ}\end{array}$ \\
\hline
\end{tabular}


Tabela 17 - Valores de P encontrado através das comparações múltiplas, pelo teste post-hoc, dos valores médios entre os tempos para cada parâmetro analisado, no sangue periférico de vacas Holandesas - São Paulo - 2013

\begin{tabular}{lccccc}
\hline \multicolumn{5}{c}{ Wilcoxon } \\
\hline AST (U/L) & M-1 & M0 & M1 & M2 & M3 \\
\hline M-2 & 0,028 & $0,003^{*}$ & $0,003^{*}$ & 0,028 & 0,013 \\
M-1 & & $0,002^{*}$ & 0,008 & 0,41 & 0,041 \\
M0 & & & 0,583 & 0,108 & 0,695 \\
M1 & & & & 0,071 & 0,062 \\
M2 & & & & & 0,61 \\
\hline
\end{tabular}

Legenda: * Diferenças significativas ( $p \leq 0,003)$; AST: Aspartato aminotransferase; $M-2$ : $2^{\circ}$ semana pré-parto; $M-1$ : $1^{\circ}$ semana pré-parto; $\mathrm{M} 0$ : dia do parto; $\mathrm{M} 1 ; 1^{\circ}$ semana pós-parto; M2: $2^{\circ}$ semana pós-parto; M3: $3^{\circ}$ semana pós-parto.

Tabela 18 - Significâncias obtidas na comparação dos parâmetros do cálcio total e cálcio ionizável no soro de vacas Holandesas entre os momentos de estudo - São Paulo - 2013

\begin{tabular}{lccccc}
\hline \multicolumn{5}{c}{ Wilcoxon } & \\
\hline Cálcio Total & M-1 & M0 & M1 & M2 & M3 \\
\hline M-2 & $0,003^{*}$ & 0,919 & 1 & 0,638 & 0,456 \\
M-1 & & $0,003^{*}$ & $0,003^{*}$ & $0,003^{*}$ & $0,002^{*}$ \\
M0 & & & 0,221 & 0,783 & $0,002^{*}$ \\
M1 & & & & 0,307 & 0,034 \\
M2 & & & & 0,008 \\
\hline Cálcio lonizável & M-1 & M0 & M1 & M2 & M3 \\
\hline M-2 & 0,007 & 0,042 & 0,574 & 0,219 & 0,157 \\
M-1 & & $0,003^{*}$ & $0,003^{*}$ & $0,002^{*}$ & $0,002^{*}$ \\
M0 & & & 0,447 & 0,439 & 0,624 \\
M1 & & & & 0,919 & 0,37 \\
M2 & & & & & 0,758 \\
\hline
\end{tabular}

Legenda: * Diferenças significativas $(p \leq 0,003) ; M-2: 2^{\circ}$ semana pré-parto; $\mathrm{M}-1$ : $1^{\circ}$ semana pré-parto; M0: dia do parto; $\mathrm{M} 1 ; 1^{\circ}$ semana pósparto; M2: $2^{\circ}$ semana pós-parto; M3: $3^{\circ}$ semana pós-parto. 
Tabela 19 - Significâncias (Valor de P) obtidas na comparação dos parâmetros, pelo teste de Wilcoxon, de leucócitos totais (células $/ \mu \mathrm{L}$ ), monócitos relativo (\%) e absoluto (células $/ \mu \mathrm{L}$ ) de vacas Holandesas entre os momentos de estudo - São Paulo - 2013

\begin{tabular}{|c|c|c|c|c|c|}
\hline \multicolumn{6}{|c|}{ Wilcoxon } \\
\hline Leucócitos totais & $\mathrm{M}-1$ & MO & M1 & $\mathrm{M} 2$ & M3 \\
\hline M-2 & 0,059 & 0,004 & 0,173 & 0,583 & 0,576 \\
\hline$M-1$ & & 0,019 & 0,033 & 0,087 & 0,184 \\
\hline MO & & & 0,004 & 0,023 & 0,004 \\
\hline M1 & & & & 0,944 & 0,6 \\
\hline M2 & & & & & 0,507 \\
\hline Monócitos (\%) & $\mathrm{M}-1$ & MO & M1 & M2 & M3 \\
\hline $\mathrm{M}-2$ & 0,284 & 0,408 & 0,321 & 0,028 & 0,107 \\
\hline$M-1$ & & 0,301 & 0,039 & 0,018 & 0,033 \\
\hline Mo & & & 0,21 & 0,007 & 0,045 \\
\hline M1 & & & & 0,123 & 0,490 \\
\hline M2 & & & & & 0,518 \\
\hline Monócitos $\left(\times 10^{3}\right)$ & $\mathrm{M}-1$ & MO & M1 & M2 & M3 \\
\hline M-2 & 0,308 & 0,534 & 0,248 & 0,012 & 0,091 \\
\hline$M-1$ & & 0,248 & 0,099 & 0,009 & 0,041 \\
\hline Mo & & & 0,131 & 0,004 & 0,026 \\
\hline M1 & & & & 0,091 & 0,735 \\
\hline M2 & & & & & 0,31 \\
\hline
\end{tabular}


Tabela 20 - Significâncias das subpopulações auxiliar (CD3+CD4+) no sangue de vacas Holandesas no período de transição em relação aos momentos de estudo - São Paulo - 2013

\begin{tabular}{|c|c|c|c|c|c|}
\hline \multicolumn{6}{|c|}{ Wilcoxon } \\
\hline Linfócitos T CD3+CD4 (\%) & $M-1$ & Mo & M1 & M2 & M3 \\
\hline M-2 & 0,041 & 0,508 & 0,575 & 0,213 & 0,131 \\
\hline$M-1$ & & 0,050 & 0,424 & 0,016 & 0,010 \\
\hline M0 & & & 0,155 & 0,013 & 0,041 \\
\hline M1 & & & & 0,010 & 0,005 \\
\hline M2 & & & & & 0,695 \\
\hline
\end{tabular}

